\title{
Capítulo 1 - A imprensa como locus de saber
}

\author{
Juliana Gesuelli Meirelles
}

\section{SciELO Books / SciELO Livros / SciELO Libros}

MEIRELLES, J. G. A imprensa como locus de saber. In: Política e cultura no governo de Dom João VI: imprensa, teatros, academias e bibliotecas (1792-1821) [online]. São Bernardo do Campo, SP: Editora UFABC, 2017, pp. 25-123. ISBN 978-85-68576-87-8. https://doi.org/10.7476/9788568576878.0002.

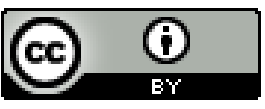

All the contents of this work, except where otherwise noted, is licensed under a Creative Commons Attribution 4.0 International license.

Todo o conteúdo deste trabalho, exceto quando houver ressalva, é publicado sob a licença Creative Commons Atribição $\underline{4.0}$.

Todo el contenido de esta obra, excepto donde se indique lo contrario, está bajo licencia de la licencia $\underline{\text { Creative }}$ Commons Reconocimento 4.0. 


\section{A IMPRENSA COMO LOCUS DE SABER}

\subsection{Preâmbulo}

A nação que não possui indivíduos capazes de arriscar-se pelo bem da Pátria, está conrompida [sic], e, portanto, arruinada; porque a nação viciosa, e sem patriotismo, há de por força ser escrava e miserável. O melhor dos soberanos, se tem a infelicidade de governar uma nação de aduladores, não poderá fazer florentes os seus Estados, nem conferir aos súditos aquela liberdade racionável, que todos os homens têm direito de exercitar, mas que a sábia Providência não deixa gozar senão às nações que praticam as virtudes civícas, as quais exornam o Cidadão, assim como as virtudes morais condecoram o pai de família.

Hipólito da Costa.

Publicada no Correio Braziliense em março de 1810, a reflexão acima era dirigida ao Partido Francês no Brasil. E a mensagem do redator era clara: a bajulação política daqueles que "não 
olham à qualidade dos meios que empregam com tanto que obtenham os seus fins" era nefasta e poderia arruinar o progresso cívico e moral da nação portuguesa. ${ }^{1}$ Seu dever diante de tal perigo era iluminar os espíritos patrióticos através do incentivo ao exercício crítico da razão. A imprensa livre das amarras da censura era o espaço por excelência para a prática desse ofício - o esclarecimento. Como cidadão da nação portuguesa, exercia-o independente do quilate político de seus interlocutores: chefes de Estado, políticos poderosos, homens comuns. Todos estavam sob a mira de Hipólito da Costa. ${ }^{2}$

Jornalista destemido, Hipólito fez do Correio Braziliense o baluarte da liberdade de pensamento da imprensa luso-brasileira no raiar do século XIX. Em um momento de grande tensão política, devido aos ecos e consequências da Revolução Francesa no Velho e no Novo Mundo, a redefinição do papel da imprensa era crucial. ${ }^{3} \mathrm{O}$ florescimeto da tipografia no Brasil e a circulação transatlântica da Gazeta do Rio de Janeiro, a partir de 1808, quase simultaneamente ao nascimento do Correio Braziliense, em Londres, mostra-nos que a imprensa se tornava um poderoso instrumento de poder político no Império Português: a disputa pelos leitores, pela conquista do lugar de primazia na formação (e condução) da opinião pública - através de linhas editoriais bem demarcadas - foi uma tônica muito marcante no período joanino,

1 CB. Vol. IV, p. 314.

2 Sobre as controvérsias do exercício de Hipólito da Costa como homem de imprensa, ver. MUNARO, Luís. "A unidade do Reino luso-brasileiro: uma discussão jornalística em Londres." VIII Encontro Nacional de História da Mídia. 2011. (p. 1-15). Disponível em: <http://paginas.ufrgs.br/alcar/encontros-nacionais-1/8o-encontro-2011-1/artigos/>. Acesso em: 20 jul. 2011.

3 Para informações mais precisas da política anti-francesa em Portugal, ver ALVES, José Augusto dos Santos. "A Revolução Francesa e o seu eco em Portugal nos arquivos da Intendência Geral da Polícia em finais do século XVIII e princípios do século XIX”. In: Revista de História e Teoria das Ideias, Lisboa, Vol. XVIII, 2004. 
sobretudo entre os anos de 1808 e 1821. Deste lado do Atlântico, a Gazeta do Rio de Janeiro e o Patriota foram, ao longo desse período, os principais meios de comunicação impressa da realeza com o Velho Mundo.

$\mathrm{Na}$ Europa, mais especificamente na capital britânica, a Coroa portuguesa fez d'O Investigador Portuguez em Inglaterra o seu jornal por excelência no combate às ideias de Hipólito da Costa. Sob a égide da liberdade de imprensa, esses dois periódicos debateriam questões centrais para a manutenção e sobrevivência da monarquia lusitana diante da crise do Antigo Regime: da defesa dos ideais políticos liberais à importância da educação pública, o novo conceito de progresso, advindo das Luzes, era o foco a ser pensado. Segundo o historiador Reinhart Koselleck, criado no final do século XVIII,

O conceito de progresso único e universal nutria-se de muitas novas experiências individuais de progressos setoriais, que interferiam com profundidade cada vez maior na vida quotidiana que antes não existiam [...] O progresso reunia, pois, experiências e expectativas a serem afetadas por um coeficiente de variação temporal. Um grupo, um país, uma classe social tinham consciência de estar à frente dos outros, ou então procuravam alcançar os outros ou ultrapassá-los. Aqueles dotados de uma superioridade técnica olhavam de cima para baixo o grau de desenvolvimento dos outros povos, e quem possuísse um nível superior de civilização julgava-se no direito de dirigir esses povos. ${ }^{4}$

Dentro dessa nova concepção de progresso, a imprensa luso-brasileira "na emigração"5 também ganhou novos atores:

\footnotetext{
4 KOSELLECK, Reinhart. Futuro Passado: contribuição a semântica dos tempos históricos. Rio de Janeiro: Ed. PUC-Rio: Contraponto, 2006. p. 317 (Grifo nosso). ${ }^{5}$ Essa expressão faz referência ao título do livro do historiador João Pedro Rosa Ferreira sobre o Correio Braziliense. FERREIRA, João Pedro Rosa. O Jornalismo na emigração. Ideologia e Política no Correio Braziliense. Lisboa: CLC/UNL, 1992.
} 
em Londres, no ano de 1814, nascia O Portuguez, de Bernardo da Rocha Loureiro, e em 1821 O Campeão Portuguez, de José Liberato de Carvalho. Em Paris, surgia em 1815 o Observador Lusitano em Paris, de Francisco Solano Constâncio, também redator dos Annaes das Sciências, das Artes e das Letras, publicação que circulou entre 1818 e 1822. Os três jornalistas, assim como Hipólito da Costa, compunham a seleta órbita da elite ilustrada luso-brasileira.

Neste capítulo, o nosso foco está na compreensão da política cultural do governo joanino, tendo a imprensa periódica como um de seus pilares fundamentais de sustentação da monarquia portuguesa. A complexidade de tal empreitada será discutida, sobretudo, pela importância que o desenvolvimento da arte e da ciência na época tinha na luta pela manutenção da independência política trilhada nas sendas dos que as concebiam como progresso.

Sob esse prisma, abordaremos a complexa produção discursiva dos diferentes atores históricos envolvidos na produção e circulação da palavra impressa, tendo em vista que, como a Europa, especificamente Portugal vivia tempos difíceis: a guerra contra Napoleão, a restauração do poder absoluto do rei no Velho Mundo, as rebeliões contra o Antigo Regime nos dois lados do Atlântico, a Revolução do Porto e as consequências advindas desse processo.

\subsection{Hipólito José da Costa na política cultural joanina}

Em junho de 1808, o jornalista Hipólito José da Costa lançava O Correio Braziliense, um dos jornais mais combativos do período joanino. De sólida formação intelectual, "Mr. da Costa", 
como era conhecido nos círculos elitizados de Londres, teve uma trajetória muito peculiar. Nascido na Colônia de Sacramento (atual Uruguai), em 1774, Hipólito era filho do alferes de ordenanças Félix da Costa Furtado de Mendonça, um rico proprietário de terras. ${ }^{6} \mathrm{O}$ contato com as leis deu-se provavelmente na adolescência, nos primeiros anos de formação, através de lições ministradas por seu tio - o padre Pedro Pereira Fernandes de Mesquita - doutor em Cânones.

Com efeito, segundo frei Manoel Veloso [...], o clérigo teria desempenhado um papel marcante na formação do jornalista não só pela instrução clássica e humanista que ele ministrou, como também pela forma como o sensibilizou para os estudos científico-naturalistas, incutindo nele uma área de interesse que o acompanharia ao longo de toda a sua vida. ${ }^{7}$

Desde a reforma da Universidade de Coimbra em 1772, a formação dos bacharéis em Leis ganhara uma nova direção. Os cursos iniciavam-se por um conjunto de cadeiras propedêuticas, em que avultavam matérias históricas e filosóficas. Segundo os estatutos, nenhum direito podia ser bem entendido sem um claro conhecimento prévio, tanto do Direito Natural, como da História Civil das Nações e das Leis para elas estabelecidas. ${ }^{8}$ Em 1791, ocorria a reforma da Faculdade de Filosofia, que incorporara

\footnotetext{
6 Para maiores informações sobre a vida familiar de Hipólito, ver DOURADO, Mecenas. Hipólito da Costa e o Correio Braziliense. Rio de Janeiro: Biblioteca do Exército, v. 234, t.1. p. 15-29.

7 PEDROSA, Alcino. “Introdução”. In: COSTA, Hipólito José da. Diário da minha viagem a Filadélfia (1798-1799). Lisboa: ICS. Imprensa de Ciências Sociais, 2007. p. 14-15 (Grifo nosso).

8 Informações sobre a Reforma Pombalina até o final do século XIX. Disponível em: <http://www.uc.pt/ciuc/fduc/faculdade/a_nossa_historia/historia_3>. Acesso em: 23 nov. 2010.
} 
algumas disciplinas científicas ao currículo. No ano seguinte, o governo português decretou uma carta régia que julgava o aproveitamento técnico e intelectual dos que cursavam a universidade. A lei tinha por objetivo conhecer "sobre as qualidades de prudência, probidade e desinteresse de cada um dos bacharéis, e mais circunstâncias que devem ter as pessoas que se destinam ao serviço do Estado".

Foi precisamente no curso de Filosofia que Hipólito ingressou em 1792, antes de seguir o curso de Direito, a partir de 1793. Portanto, a formação intelectual do futuro redator do Correio Braziliense era diferenciada: durante o ano em que frequentou a cadeira da Faculdade de Filosofia, teve aulas de Botânica, Agricultura, Zoologia, Mineralogia, Física, Química e Metalúrgia. Em Botânica, foi discípulo de Félix de Avelar Brotero, mestre muito admirado "porque humanizava os seus sólidos conhecimentos científicos com o amor às ideias liberais". ${ }^{10}$ Esta postura política de viés liberal obrigaria o cientista a exilar-se em Paris em 1778, onde viveu até $1790 .^{11}$

${ }_{9}$ DOURADO, Mecenas. Hipólito... Op. Cit., p. 34.

${ }^{10}$ Ibid., Cap. VI, t.1, p. 45.

${ }^{11}$ Doutor em medicina pela Universidade de Reims, Félix de Avelar Brotero (1744-1828) foi lente da cadeira de Botânica e Agricultura na Universidade de Coimbra e diretor do Museu Real e Jardim Botânico do Paço da Ajuda. Sócio da Academia Real das Ciências de Lisboa; da Academia de História Natural e Filomática de Paris; da Fisiográfica de Lunden na Suécia; da de História Natural de Rostock, e da Academia Cesarea de Bona na Alemanha, etc. Na Inglaterra, foi membro da Sociedade de Horticultura de Londres, e da Lineana de História Natural. Em meio às primeiras convulsões políticas da Revolução Francesa, deixou Paris e retornou à Lisboa em 1790, na companhia de D. Francisco de Meneses. Voltava a Portugal com grande reputação de sábio: foi logo nomeado lente de Botânica e Agricultura na Universidade de Coimbra, pelo decreto de 25 de Fevereiro de 1791. Na capital francesa, publicou a obra que o deixaria célebre na Europa, o Compendio de Botânica ou noções elementares desta ciência, segundo os melhores escritores modernos, expostos na língua portuguesa, de 1788. Nas primeiras preleções, Brotero foi ouvido com grande entusiasmo tanto por 
A atenção e zelo que Hipólito despendeu para os mestres e os estudos o distinguiam dos demais estudantes da universidade aos olhos dos ministros reais, sobretudo D. Rodrigo de Souza Coutinho, que já em $1798^{12} \mathrm{o}$ incumbia de uma missão muito especial nos Estados Unidos: enviava-o "com a finalidade de estudar os progressos verificados neste país no campo das artes plásticas, da agricultura e das manufaturas". Nesse momento, D. Rodrigo ocupava o cargo de Ministro de Estado da Marinha e Domínios Ultramarinos (1796-1801), época em que publicou a obra Sobre os melhoramentos dos domínios de S. Majestade na América (1797), que já delineava as linhas de seu programa de reformas ilustradas. Como assevera o historiador Guilherme Pereira das Neves, esse projeto pretendia

[...] reforçar a unidade do império como um todo, por meio da concepção de um império luso-brasileiro, cuja ideia deveria ser inculcada nos portugueses das quatro partes do mundo, graças a uma elite de talentos, através de mecanismos modernos como a escola, e de outros nem tanto, como a Igreja. ${ }^{13}$

discípulos quanto por muitos doutores e mestres de outras faculdades, atraídos pelo vasto saber, clareza e amenidade de tão hábil professor de Botânica. Iniciou a primeira Escola Prática de Botânica, organizando o jardim com uma classificação científica, e enriquecendo-o com os exemplares indispensáveis para o estudo. A sua atuação na direção do Jardim Botânico da Ajuda será tema detalhada ao longo do capítulo. BROTERO, Félix de Avelar. In: Dicionário Histórico PORTUGAL. Disponível em: <http://www.arqnet.pt/dicionario/brotero.html>. Acesso em: 23 nov. 2010.

12 Neste ano, Hipólito se formava em Leis pela Universidade de Coimbra com importante destaque acadêmico.

13 NEVES, Guilherme Pereira Das. "Rodrigo de Souza Coutinho, conde de Linhares”. In: NEVES, Lúcia Bastos Pereira das; VAINFAS, Ronaldo. Dicionário do Brasil Joanino. Op. Cit., p. 399 (Grifo nosso). Para uma análise mais detalhada sobre o projeto reformista de D. Rodrigo de Souza Coutinho, ver: LYRA, Maria de Lourdes Viana. A utopia... Op. Cit., p. 61-106. ; SILVA, Andrée Mansuy-Diniz da. Portrait d'un homme d'État: D. Rodrigo de Souza Coutinho, Comte de Linhares, 1755 - 1812. Lisboa: Fundação Calouste Gulbenkian, 2006. p. 63-126. 
Hipólito da Costa era um dos destaques promissores dessa elite de talentos; razão pela qual Souza Coutinho também lhe destinava um encargo secreto de espionagem econômica, relacionado à recolha do inseto e planta da cochonilha, criados no México pelos espanhóis e que mantinham um alto valor para a indústria têxtil. ${ }^{14}$ Em carta enviada ao ministro real, Hipólito explicava detalhadamente as suas dificuldades na obtenção e conservação da cochonilha, que deveria ser de muita utilidade para o desenvolvimento econômico do Brasil.

[...] há grandes obstáculos para obter a semente, porque não havendo daqui comunicação com o México, é necessário passar a Havana para me poder transitar a Vera Cruz. A primeira dificuldade é poder exportar de Vera Cruz para Havana a planta e inseto sem que seja percebido, porque tal exportação é proibida debaixo de grandes penas.

A questão da diferença climática entre o Brasil e os Estados Unidos era outro viés relevante no transporte da semente. "O único meio que lembro para vencer esta dificuldade será esperar um navio que vá dos Estados Unidos com escala para o Brasil, e fazer passar nele a planta, no caso de se poder obter de Havana"15, informava o enviado. Para além desta obrigação econômica, a breve temporada nos Estados Unidos lhe deixaria uma marca fundamental: a iniciação na Maçonaria, na Filadélfia, que acabaria por encerrar, em 1805, as relações amistosas e de proteção que tivera desde então com Souza Coutinho e o governo português. Sua iniciação na Maçonaria foi justificada pelo fato de a associação ser um espaço de circulação de ideias com debates intelectuais profícuos para o homem desenvolver e aprimorar

${ }^{14}$ PEDROSA, Alcino. "Introdução”... Op. Cit., p. 17.

15 COSTA, Hipólito José da. Diário... Op. Cit., p. 151-152 (Grifo nosso). 
o espírito público através da virtude. “[...] Por todos os homens que, naquele País [Estados Unidos], conheci notáveis, em ciência e representação civil: este contraste foi o poderoso motivo, que excitou a minha curiosidade e me fez solicitar a admissão a esta Ordem", dizia Hipólito, ao exaltar perante os inquisidores lusitanos o comportamento retrógrado das autoridadades portuguesas, que perseguiam homens intitulados francomaçons "talvez sem que o fossem e que a voz pública afirmava", tratando-os com um "rigor indesculpável". 16

A partir desta época, sua permanência em Londres estaria atrelada à profunda relação de amizade que travara com o Duque de Sussex, filho do rei Jorge III da Inglaterra, quando este vivera em Portugal, entre 1801 e $1805 .{ }^{17}$ Destarte, foi sob a proteção de Sussex que Hipólito garantiu a "imunidade [necessária] contra as tentativas da Coroa Portuguesa de extraditá-lo" 18 por conta das suas influências maçônicas. Como assevera o historiador Alexandre Mansur Barata, desde o final do século XVIII, a repressão da Coroa portuguesa aos maçons foi "aos poucos deixando de ser tratada apenas como um crime contra a fé católica e, portanto, sob a alçada precípua do Santo Ofício, para ser tratada como um crime político, uma ameaça ao Estado absoluto." ${ }^{19}$ Ainda segundo

\footnotetext{
16 MENDONÇA, Hipólito José da Costa Pereira F. de. Narrativa da Perseguição de Hippolyto Joseph da Costa Pereira Furtado de Mendonça, natural da Colonia do Sacramento, no Rio da Prata. Preso e processado em Lisboa pelo presente crime de Framaçon ou Pedreiro Livre. Londres: W. Lewis, 1811. v. 1, p. 22. Sobre a posição de Hipólito da Costa dentro da hierarquia maçônica na Inglaterra, ver DOURADO, Mecenas. Hipólito... Op. Cit., Cap. VIII, t.1, p. 119-120.

17 Sobre o drama pessoal do Príncipe de Gales (Duque de Sussex) vivido em Portugal, ver DOURADO, Mecenas. Hipólito... Op. Cit., Cap. VII, t.1, p. 101-110.

18 LUSTOSA, Isabel. "A pátria de Hipólito" In: COSTA, Hipólito José da. Correio Braziliense ou Armazém Literário. São Paulo: SP: Imprensa Oficial do Estado; Brasília, DF: Correio Braziliense, 2001, p. XLIX.

19 BARATA, Alexandre Mansur. Maçonaria, Sociabilidade Ilustrada e Independência do Brasil (1790-1822). São Paulo-Juiz de Fora: Annablume-EDUFJF-
} 
Barata, a maçonaria se consolidava no mundo luso-brasileiro como um instrumento político muito sedutor, já que seu discurso "enfatizava a imagem de uma sociedade que se estruturava a partir da ideia de igualdade, onde reis e súditos dividiam o mesmo espaço e cumpriam as mesmas obrigações, comprometendo a se amarem, a se ajudarem e a se respeitarem". ${ }^{20}$ Em contrapartida, a ação política e administrativa da monarquia também construía no interior da sociedade "uma imagem de maçonaria identificada com o complô, com a maldade, com a sedição". ${ }^{21} \mathrm{Na}$ prática, portanto, a Inquisição - como tribunal eclesiástico e da Coroa -, perseguia os maçons por considerá-los ao mesmo tempo "maus católicos e maus vassalos". ${ }^{22}$

Na capital inglesa, Hipólito da Costa não só foi nomeado o "secretário para assuntos estrangeiros da Grande Loja”, como ainda escreveria o Correio Braziliense ou Armazém Literário (1808 - 1822), considerado por muitos historiadores o primeiro jornal brasileiro independente. ${ }^{23} \mathrm{O}$ fato é que a proximidade com um

-FAPESP, 2006. p. 65-70, (Grifo nosso). No item "A inserção da sociabilidade maçônica na América Portuguesa" (p. 53-91), o autor mostra os pontos centrais do desenvolvimento da Maçonaria em Portugal (Lisboa, Coimbra, Madeira), assim como casos específicos ocorridos no Brasil, no período. Um bom exemplo é o do carioca Antonio Morais Silva, que sofreu as consequências da denúncia de Francisco Cândido Chaves à Mesa do Tribunal do Santo Ofício, em 1799, por ser considerado maçom.

${ }^{20}$ Ibid., p. 110.

${ }^{21}$ Ibid., p. 148.

22 Ibid., p. 154. “... a principal preocupação [dos inquisidores] era perceber até que ponto o pertencimento à maçonaria significava a adoção de um afrontamento aos dogmas católicos e colocava em perigo o poder do rei." (Ibid., p. 166.).

23 ARAÚJO, Paulo Cabral. "Construção da Memória” In: Correio Braziliense. Vol. I, p. xix. Sobre os diversos olhares acerca da figura de Hipólito e do Correio Braziliense, ver os artigos de Barbosa Lima Sobrinho, José Mindlin, Sérgio Kobayashi, Alberto Dines e Isabel Lustosa, publicados neste mesmo volume, p. ix a liv. Para a compreensão do nascimento e desenvolvimento da maçonaria em Londres durante o século XVIII, ver BARATA, Alexandre Mansur. Maçonaria... 
membro da família real britânica, também maçom, garantia-lhe "desfrutar na Inglaterra certo prestígio social e comodidades materiais, difíceis, senão quase impossíveis, sem ela, para quem não possuía grandes haveres". ${ }^{2}$

Esta situação particularizada do jornalista teve importantes contornos políticos no mundo da imprensa interatlântica, conforme veremos mais adiante. As negociações e a tentativa de controle da pena de Hipólito por parte da Coroa foram atividades constantes ao longo dos quatorze anos de vigência do Correio Braziliense. ${ }^{25}$ A estreita ligação com a maçonaria e as críticas ao governo português e à política internacional, fossem contundentes ou não, justificavam esta postura real. Porém, o que nos interessa mostrar é que a Coroa tentava amenizar a influência do jornalista, porque conhecia o potencial intelectual de Hipólito e o provável alcance das suas reflexões na formação moral e,

Op. Cit., p. 22-26. O pesquisador José Carlos de Oliveira também faz uma interessante discussão historiográfica sobre a importância do Correio Braziliense para a História da Imprensa no Brasil no seu artigo. Cf. OLIVEIRA, José Carlos. "Os periódicos portugueses de Inglaterra e a Cultura Científica Brasileira (18081821)". Revista da SBHC, n.19, 1998, p. 31-62.

${ }^{24}$ DOURADO, Mecenas. Hipólito... Op. Cit., Cap. VII, t.1, p. 108-109. Segundo Mansur, o auxílio mútuo era outro fator que impulsionavam as pessoas a se iniciarem na maçonaria. "Outra motivação muito citada era que o pertencimento à maçonaria facultava ao iniciado uma ampla rede de auxílios mútuos. Num tempo em que os meios de comunicação eram precários, de guerras, de diferenças religiosas, onde os deslocamentos, tanto por mar quanto por terra, eram demorados e inseguros, pertencer a uma sociedade que apontava para o estabelecimento de uma rede de proteção era algo extremamente sedutor", afirma Mansur. Ibid., p. 111.

${ }^{25}$ A circulação d' O Correio foi proibida pela Coroa em três momentos diferentes - em 1810, 1812 e 1817- porém sem grandes efeitos, uma vez que tanto o Brasil quanto Portugal recebiam o jornal pelos circuitos clandestinos de informação. PAULA, Sérgio Goes de. "Hipólito José da Costa e o Correio Braziliense ou Armazém Literário". In: PAULA, Sérgio Goes de. (Org.). Hipólito José da Costa. São Paulo: Ed. 34, 2001. p. 22. 
consequentemente, educacional de seus súditos. Muitas das propostas e análises do redator do Correio entravam em choque com a concepção da monarquia portuguesa do que seria um vassalo fiel.

$\mathrm{Na}$ sociedade do Antigo Regime, a civilidade era o atributo por excelência de um súdito exemplar. Não por acaso, o ato de ser civil era pedagogicamente ensinado para os jovens da sociedade joanina através de obras de ficção e não-ficção de caráter moral, ou pela força da tradição aristocrática portuguesa. ${ }^{26} \mathrm{Como}$ bem definia a obra Elementos da Civilidade e da decência, para instrução da mocidade de ambos os sexos,

Não é a verdadeira civilidade outra coisa senão $a$ prática das regras da decência, ou a ciência do bem regrar os discursos, e ações na vida civil. Esta ciência não é uma virtude adventícia, nem simples dom da natureza, mas uma ciência adquirida, e como definem os antigos, uma ciência que ensina e põe no seu devido lugar o que temos de fazer, ou dizer. ${ }^{27}$

No capítulo XV, "Da Importunação", o autor definia as características do homem inoportuno, considerado incivil. Como ciência a ser "adquirida" social e moralmente, a incivilidade era

${ }^{26}$ Para conhecer a diversidade das obras de ficção produzidas pela Impressão Régia no período joanino e seu caráter moralizador, ver: SOUZA, Simone Cristina Mendonça de. Primeiras impressões: romances publicados pela Impressão Régia do Rio de Janeiro (1808-1822). Tese de doutorado. IEL. Unicamp. 2007. Em relação às leituras consideradas libertinas e sua relação com a maçonaria, ver: VILLALTA, Luiz Carlos. "Libertinagens e livros libertinos no mundo luso-brasileiro". In: ALGRANTI, Leila Mezan, MEGIANI, Ana Paula Torres (Org.). O Império por escrito: formas da transmissão da cultura letrada no mundo ibérico (Sécs. XVI-XIX). São Paulo: Ed. Alameda, 2009. p. 523-563.

27 "Discurso Preliminar" In: Elementos da Civilidade e da decência, para instrução da mocidade de ambos os sexos: traduzidos do francês em vulgar. Lisboa: Tipografia Rollandiana, 1801, s/n. Com Licença do Desembargo do Paço (Grifos do original). 
considerada o maior dos pecados de um vassalo leal, já que este era um erro voluntário que não merecia desculpas. O inoportuno era insolente e petulante, sendo a insolência sinal de desprezo e ofensa que aliena o espírito; assim como a petulância, sinônimo de insubordinação e desrespeito ${ }^{28}$, não só com a figura real, mas, sobretudo, com o status quo. Por esse prisma, vemos que o desenvolvimento moral do súdito esclarecido estava circunscrito à esfera da responsabilidade do Estado. Isto é, para manter a integridade política do Império Português nos dois lados do Atlântico, o "esclarecimento" de seus súditos - que deveriam ser úteis ao governo - era uma prerrogativa fundamental. Propositadamente, a fundação do Seminário de Olinda (1796) estava sob a direção do bispo Azeredo Coutinho, um dos homens mais destacados da Colônia. Como já demonstrou a historiadora Maria de Lourdes Viana Lyra, a leitura do estatuto da instituição coloca em evidência a faceta deste órgão como um locus de ampla educação dos homens que comporiam o quadro administrativo do Império, um viés de destaque na prática política do reformismo ilustrado português. Nas palavras da autora,

O objetivo central da proposta [do Seminário era]: "criar e estabelecer na cidade de Olinda um Colégio para se instruir a mocidade", no estudo das ciências e das artes, com o devido alerta para que fossem transmitidas somente "aquelas que são necessárias" à formação dos agentes integrados na execução do projeto político implícito no programa reformista, ou seja, a formação de uma nação atlântica representada pelo novo império. ${ }^{29}$

\footnotetext{
${ }^{28}$ Elementos da civilidade e da decência, para instrução da mocidade de ambos os sexos: traduzidos do francês em vulgar. Lisboa: Tipografia Rollandiana, 1801. p. 118-119.

29 LYRA, Maria de Lourdes Viana. A utopia... Op. Cit., p. 89 (Grifos do original). Para informações mais aprofundadas sobre a carreira e atuação de Azeredo Coutinho no Seminário de Olinda, ver a mesma obra, p. 88-96.
} 
Portanto, a grade curricular do espaço tal como as leituras indicadas eram itens de relevância, incluindo-se aí o já citado Elementos da civilidade e da decência. ${ }^{30} \mathrm{O}$ destaque também se dá para a segunda parte da obra, intitulada "Arte de Agradar na Conversação". Neste capítulo, o autor ressaltava a atenção que o homem civil deveria ter no uso das palavras nas contendas e debates, e na narração de histórias, feitos e novidades. Mesmo referindo-se à oralidade, tais regras também podiam ser estendidas para a palavra escrita. A finalidade deste aprendizado - a ciência da civilidade -, era tão valorizada na sociedade de Corte que, já em 1809, encontramos na Gazeta do Rio de Janeiro um anúncio sobre o início de aulas de Gramática Portuguesa e Latina, ministradas por um professor recém-chegado de Lisboa: suas aulas aconteciam na freguesia de Santa Rita no Beco dos Quartéis, n. 5, e tinham como foco o ensino da ampla moral aristocrárica. O professor se comprometia a

Ensina[r] com perfeição possível a Gramática de Língua Portuguesa, com a sua Ortografia; e Escrituração debaixo de um Caráter de letra, o mais perfeito: Ciência de Contar, debaixo de todos os preceitos Matemáticos; Gramática Latina, Filosofia racional, e moral, em diferentes horas do dia: também as tratará em certos dias de Política e Civilidade Cristã: desde às7 horas da noite por diante, estará a Aula aberta, só propriamente para Caixeiros, que, em razão das suas ocupações, não poderão concorrer de dia. O Professor terá muita satisfação e honra em que os Pais de Família entrem bem na indagação do sistema, porque o

\footnotetext{
${ }^{30}$ Esta obra compunha a coleção de livros do servidor público da Coroa Jerônimo da Silva Guimarães em Sabará (MG) no início do século XIX. FONSECA, Thais Nivia de Lima e. "Portugueses em Minas Gerais no Século XVIII: cultura e escrita e práticas educativas” In: Anais do II Encontro Internacional de História Colonial. Mneme - Revista de Humanidades. UFRN. Caicó (RN), v. 9. n. 24, Set/ out. 2008, p. 8.
} 
dito ensina cada uma das coisas, que promete. Abre-se a Aula no $1^{\circ}$ de Julho de $1809 .{ }^{31}$

Segundo a historiadora Iara Lis Schiavinatto,

As finalidades da leitura - diziam os tratadistas de fins do Setecentos - residiam na formação do estilo de escrita, na instrução, na diversão com vícios e perigos inclusos, no aprendizado da organização dos próprios textos, na memorização dos saberes e na tentativa (bem sucedida ou não) de imitar estilos. ${ }^{32}$

Como súdito da monarquia portuguesa e também formador da opinião pública, Hipólito da Costa cometia o "pecado mortal" da incivilidade: além de maçom, muitas vezes, era "inoportuno" no uso de suas palavras. Ao produzir o Correio em Londres, onde vigorava a imprensa livre, o periodista fazia da arena pública de debate político seu espaço por excelência. Apesar disso, não podemos nos esquecer de que Hipólito era explicitamente partidário dos ideais políticos da monarquia constitucional britânica, tendo estreitado ao longo da vida seus laços "afetivos" no país. $\mathrm{O}$ redator ainda escrevia em um contexto de grave crise europeia, que ganhou mais força desde o Bloqueio Continental, quando França e Inglaterra passaram a disputar explicitamente a hegemonia política e econômica no Velho Mundo. Como principal aliada da Coroa Portuguesa, a Inglaterra foi a grande financiadora das guerras napoleônicas. Nas palavras de Eric Hobsbawm, “o fardo britânico deveu-se ao custo de suportar não só o próprio

\footnotetext{
${ }^{31}$ GRJ. 1809. N. ${ }^{\circ} 81$ (Grifos nossos).

32 SCHIAVINATTO, Iara Lis. "Entre os manuscritos e os impressos" In: LESSA, Mônica Leite; FONSECA, Sílvia C. Pereira de Brito. Entre a monarquia e a república: imprensa, pensamento político e historiografia (1822-1889). Rio de Janeiro: Eduerj, 2008. p. 14.
} 
esforço de guerra do país, mas também, através dos seus tradicionais subsídios aos aliados continentais". ${ }^{33}$ Tal estratégia deu aos britânicos o fardo mais pesado desse conflito bélico; sendo entre três e quatro vezes maior do que o gasto francês. Até a queda de Bonaprte (1814), portanto, a imprensa europeia, em geral, e a luso-brasileira, em particular, usavam seu discurso jornalístico como arma de guerra. Especialmente em relação à tradição ibérica, o pesquisador Fernando Nicolazzi nos mostra que desde o início do século XVIII

[...] letras e armas são termos que se coadunavam para estabelecer as relações entre pretensões políticas e intenções literárias. [...][e] estabelecem certa reciprocidade a partir da qual linguagem e experiência, palavra e ação, ciência e política misturam-se de modo que a tarefa do literato e aquela do militar podem ser equiparadas segundo príncipios equivalentes. ${ }^{34}$

Por esse prisma, consideramos a delimitação do público leitor do Correio de suma importância, sobretudo se considerarmos as ideias maçônicas um ponto de diálogo muito frutífero entre os homens de letras e armas da época. Ademais, as leituras habituais dos pedreiros-livres - como Cândido, de Voltaire, Cartas Persas de Montesquieu e Júlia ou a Nova Heloísa, de Rousseau -, faziam parte do rol das obras consideradas ímpias e estritamente proibidas pela Coroa. Segundo Luiz Carlos Villalta, tais autores "constituiriam uma espécie de biblioteca maçônica, que traria os

\footnotetext{
${ }^{33}$ HOBSBAWM, Eric. J. A era das revoluções. Europa 1789-1848. Trad. Maria Tereza Lopes Teixeira. Marcos Penchel. 6. ed. Rio de Janeiro: Ed. Paz e Terra, 1988. p. 116.

34 NICOLAZZI, Fernando. Entre 'letras \& armas', a história como disputa. Considerações sobre a historiografia luso-brasileira no século XVIII. Almanack Braziliense. São Paulo, n.11, p. 41-42. (maio de 2010).
} 
ensinamentos fundamentais a serem seguidos pelos irmãos"35; aspecto que tornava ainda mais temerosa a figura de "Mr. da Costa" diante dos detentores do poder.

Com circulação nos dois lados do Atlântico, inclusive na América Espanhola, o Correio era lido prioritariamente por intelectuais, médicos, advogados, negociantes e, obviamente, por homens de Estado do governo joanino e hispânico. O amplo circuito de comunicação em que estava imerso o jornal de Hipólito despertava a máxima atenção da Coroa joanina, especialmente de D. João. O chefe supremo da monarquia portuguesa soube utilizar de forma perspicaz as inteligentes reflexões desse "perigoso" vassalo na condução política de seu governo. ${ }^{36}$

$\mathrm{Na}$ prática, portanto, as ações reais no combate às ideias de "Mr. Da Costa" demonstram um viés importante da política cultural joanina: cercear ao máximo a circulação na comunidade luso-brasileira de ideais políticos que ameaçassem ainda mais a já frágil estabilidade da monarquia absolutista portuguesa ${ }^{37}$, até porque os leitores do Correio eram, prioritariamente, aqueles a

35 VILLALTA, Luiz. "Libertinagens e livros... Op. Cit., p. 538.

${ }^{36}$ Em relação à circulação e leitura do Correio Braziliense na América Espanhola, o historiador João Paulo G. Pimenta, afirma: "Não há dúvidas de que, desde o início, [o Correio] circulava profusamente em toda a América, sendo folheado até mesmo pelos homens de Estado [...] por figuras de destaque da política hispânica, como Francisco de Miranda e muito provavelmente Simón Bolívar." PIMENTA, João Paulo Garrido. O Brasil e a América Espanhola (1808-1822). Tese de doutorado. São Paulo: USP, 2003. p. 43.

37 Sobre o debate público da Coroa portuguesa contra o Correio Braziliense pela imprensa oficial (Gazeta de Lisboa e Gazeta do Rio de Janeiro), ver MEIRELLES, Juliana. Imprensa e poder ... Op. Cit., p. 137-140. Quanto às primeiras tentativas diplomáticas da Coroa de cerceamento da pena do jornalista, conferir: BARATA, Alexandre Mansur. Maçonaria... Op. Cit., p. 190-195. DOURADO, Mecenas. Hipólito... Op. Cit., t.1., p. 263-313; t.2, p. 373-422.; RIZZINI, Carlos. Hipólito da Costa e o Correio Braziliense. São Paulo: Companhia Editora Nacional, 1957. p. 26-50. 
quem a Coroa desejava atingir. Segundo a historiadora Rossana Nunes, "era preciso evitar que o espírito revolucionário se infiltrasse em Portugal e seus domínios, garantindo, dessa maneira, a permanência da ordem tradicional, abalada pelos acontecimentos que seguiram a 1789". Ainda de acordo com a pesquisadora, essa postura se refletia no cotidiano do Império Português através da vigilância dos indivíduos - desde suas práticas e conversas à política de evitar que estes mantivessem contato com estrangeiros supostamente afeiçoados aos princípios franceses e residentes em Portugal. A atenção para os discursos desrespeitosos em relação ao poder monárquico e à religião, assim como o impedimento de práticas consideradas libertinas e obscenas também faziam parte do rol das "regras" sociopolíticas aceitáveis. Obviamente, a coibição, introdução e difusão de obras ditas ímpias e sediciosas eram alvo de atenção das autoridades luso-brasileiras. ${ }^{38}$

O fato de Hipólito ser um árduo defensor do modelo monárquico constitucional britânico era um fator de grande preocupação das autoridades oficiais. Na série de ensaios intitulada $\mathrm{Pa}$ ralelo da constituição Portuguesa com a Inglesa, o escritor iniciou a interlocução com seus leitores, chamando-os a atenção para os benefícios da verdade. "Jamais pude acomodar-me à opinião que muitas verdades se não deve dizer ao público. Verdade é a conformidade das nossas ideias com os objetos que elas representam; ou com as ideias eternas; a verdade logo nunca pode ser nociva aos homens: o engano é mister de outros enganos para se sustentar", defendia. ${ }^{39}$ Nessa longa reflexão, publicada em sete partes na seção "Miscelânea", o autor apontava as diferenças entre os sistemas

38 NUNES, Rossana Agostinho. Nas sombras da libertinagem. Francisco de Mello Franco: entre luzes e censura no mundo luso-brasileiro (1757-1822). Dissertação de Mestrado. UFF. 2011. p. 44.

39 CB, Vol.III, p. 175. 
políticos português e inglês, ressaltando as razões da superioridade inglesa. ${ }^{40}$

[...] a forma de Governo, em Portugal, é monárquica, e a monarquia hereditária e absoluta; em Inglaterra, a forma de Governo é monárquica, e hereditária, porém mista; por quanto [sic] o poder legislativo reside no Parlamento [...] e com o poder de fazer leis existe nesta corporação à que o Rei pertence; a ela atribuem graves Jurisconsultos Ingleses a suprema, e absoluta autoridade do Estado. ${ }^{41}$

A despeito das diferenças conceituais dos sistemas monárquicos em questão, Hipólito defendia o respeito dos súditos à autoridade real. Não era partidário, contudo, de que o "Soberano possa tudo, em toda a parte e em todas as ocasiões", sendo este obrigado a obedecer às leis, uma vez que "os governos foram instituídos a benefício dos povos e não dos que governam". ${ }^{42}$ Nesse sentido, ao mesmo tempo em que incentivava os portugueses a conservarem a pureza desta forma de governo por tê-los feito felizes durante séculos, também os alertava de que o conhecimento era necessário para que saíssem do estado de ignorância em que a Coroa os inserira com a vigência de um rigoroso sistema de censura, ao qual o jornalista era radicalmente contrário. ${ }^{43}$ Aliás, para

\footnotetext{
40 Para uma análise pormenorizada sobre a importância desta discussão, ver: DOURADO, Mecenas. Hipólito... Op. Cit., t.II, cap. XXV, "Paralelo da Constituição Portuguesa com a Inglesa" (p. 449-470). Sobre a tentativa de uma aliança entre Hipólito e o governo português, D. Domingos de Souza Coutinho lhe prometia a compra de 500 exemplares do Correio, caso o jornalista moderasse e/ou suprimisse suas análises, sobretudo nos temas mais espinhosos: a maçonaria, a religião e o paralelo entre as duas constituições (inglesa e portuguesa). Ibid., t. II, p. 375.

${ }^{41}$ CB, Vol.III, p. 379 (Grifos nossos)

${ }^{42}$ Ibid., p. 529 e 536, respectivamente.

43 Para conhecer o sistema de censura ver ALGRANTI, Leila Mezan. Livros de Devoção... Op. Cit.
} 
Hipólito, a irrestrita liberdade de imprensa era intrínseca ao progresso de uma nação que se pretendia civilizada." "Os homens, que desejam atraiçoar o Soberano, começam, por insinuar-lhe que lhe deve quartar [sic] a liberdade de imprensa, e que se não deve deixar saber ao público nem verdades, nem novidades algumas: porque a ignorância geral é o seu melhor escudo" ${ }^{35}$, bradava o periodista, ao criticar a postura dos ministros reais na relação com o Príncipe Regente. A maneira como supostamente Antonio de Araújo Azevedo teria conduzido as notícias acerca da invasão francesa a Lisboa antes da saída da Corte, foi alvo de sua análise em novembro de $1808 .{ }^{46}$

A maior parte das gazetas Inglesas asseverou, e se fez publicíssimo: que o Ministro dos Negócios Estrangeiros e da

${ }^{44}$ Utilizamos aqui o conceito de civilização defendido pelo filósofo alemão Norbert Elias em O Processo Civilizador: uma história dos costumes. Rio de Janeiro: Jorge Zahar Editor,1994. Vol.1., p. 23. Segundo o autor, "O conceito de "civilização" refere-se a uma grande variedade de fatos: ao nível da tecnologia, ao tipo de maneiras, ao desenvolvimento dos conhecimentos científicos, às ideias religiosas e aos costumes. Pode-se referir ao tipo de habitações e às maneiras como homens e mulheres vivem juntos, à forma de punição determinada pelo sistema judiciário ou ao modo como são preparados os alimentos [...]. Se examinarmos o que realmente constitui a função geral do conceito de civilização, e que qualidade comum leva todas essas várias atitudes e atividades humanas a serem descritas como civilizadas, partimos de uma descoberta muito simples: este conceito expressa a consciência que o Ocidente tem de si mesmo. Poderíamos até dizer: a consciência nacional."

${ }^{45} \mathrm{CB}$, Vol.III, p. 563

46 Antônio de Araújo de Azevedo (1754-1817) acumulou as pastas de Ministro e Secretário de Estado dos Negócios Estrangeiros e da Guerra e de Ministro do Reino entre os anos de 1804 e 1806. Neste período, sua ação na Corte Joanina se destacou pelo seu trabalho em prol do desenvolvimento artístico, científico, industrial e militar de Portugal. Mais informações sobre a trajetória política de Azevedo em PINHEIRO, Andréa de Souza; MUNIZ, Luciana."Antônio de Araújo de Azevedo, o Conde da Barca: política, ciências e saberes na biblioteca de um diplomata português." Disponível em: <http://bndigital.bn.br/200anos/ araujense.html>. Acesso: 15 jan. 2011. 
guerra de S.A. o Príncipe Regente de Portugal, ao tempo de sua partida para o Brasil, ocultara do Conhecimento do Soberano a marcha das tropas Francesas: disse-me mais, que ele ou fizera por querer atraiçoadamente entregá-lo aos seus inimigos. Eu declaro altamente, que não sei se isso é assim, senão; só repito o rumor que se fez público, e que ninguém até agora contradisse; para nisso fundamentar o meu raciocínio; basta-me o rumor, para que eu admita a possibilidade do caso. Mas como pela precipitação da retirada de S.A. se prova que S.A. não sabia da chegada dos Franceses, cuido que se segue, que os seus Ministros o não informaram da marcha daquelas tropas inimigas; marcha, que ninguém ignorava aqui em Inglaterra. Por uma de duas razões aquele ministro da guerra não informou a S. M., ou porque não sabia da marcha dos Franceses, ou porque a queria ocultar; no primeiro caso a sua ignorância o declara incapacíssimo de lugar [sic], que ocupava; no segundo caso, nada menos que uma forca devia ser o prêmio de seus merecimentos. ${ }^{47}$

O rígido olhar do jornalista para o possível silêncio (e traição) de Azevedo indicava, inclusive, uma provável aliança do ministro com as tropas francesas. Essa desconfiança ganha mais sentido se levarmos em conta a lógica diplomática do ministro dos Negócios Estrangeiros e da Guerra, que tentava evitar ao máximo o choque com Napoleão Bonaparte. Às vésperas da partida da Corte para o Brasil, Azevedo era partidário de que tal decisão ficasse mais explícita para a França, acreditando, com isso, ser capaz de evitar a entrada dos exércitos napoleônicos em solo português. Como nos aponta Jorge Pedreira e Fernando Costa, Araújo não só tinha conhecimento sobre o perigo iminente da invasão das tropas napoleônicas na Península Ibérica, como também tinha ciência de que Portugal podia "se tornar uma peça

${ }^{47}$ CB, Vol.I, p. 519 (Grifos nossos). 
importante no xadrez da repartição em escala europeia das ambições e influências políticas que Bonaparte administrava." 48 A despeito da gravidade da situação, o ministro optara por se calar; o que causou a revolta de Hipólito.

A postura "incômoda" de Azevedo já tinha sido anotada por D. Rodrigo de Souza Coutinho em 1797, em meio à ebulição da Revolução Francesa. Dizia Coutinho:

Estimo muito Antonio de Araújo, mas estou persuadido que não pode Portugal fazer uma paz particular com a França que lhe seja vantajosa, e que toda a paz sem risco não pode S.A.R. afastar-se da aliança de Inglaterra. As cartas de Araújo provam claramente que S.A.R. o Príncipe Nosso Senhor não é informado de todas as ordens que se deixam aos Ministros, e de outro modo tenho toda a razão de crer que a voz púbica não deixa de ter fundamento, no que diz da venalidade da Repartição. ${ }^{49}$

Nesta insinuação acerca do reprovável comportamento de Araújo, Souza Coutinho igualmente enaltecia a sua maneira de administrar as questões da órbita política, uma vez que ele "fiel e escrupulosamente" encaminhava tudo o que recebia "à Real

48 PEDREIRA, Jorge; COSTA, Fernando Dores. D. João VI... Op. Cit., p. 178. Ainda segundo os autores, "Na carta dirigida a D. João, em 21 de novembro, Antônio Araújo sugeriu que se convocasse logo o Conselho de Estado. Estando o perigo vizinho, era necessário que os conselheiros voltassem a votar e se pronunciassem a respeito dos preparativos para a retirada do príncipe, se deviam prosseguir menos ocultamente até porque, conhecendo os preparativos, talvez os franceses não entrassem. Para o ministro dos Negócios Estrangeiros, tudo servia como instrumento diplomático para a dissuasão da invasão francesa, até os preparativos da retirada. A verdade, porém, é que as bases em que até então se assentavam a estratégia do governo de Lisboa haviam ruído estrondosamente". (Idem)

${ }^{49}$ ANRJ, Negócios de Portugal, caixa 716, pacote 3. Apud SILVA, Andrée Mansuy-Diniz da. Portrait... Op. Cit., p. 426. 
Presença sem alteração alguma." ${ }^{50}$ Este comentário já sinalizava para as diferenças e disputas político-ideológicas que permearam a conflituosa relação desses dois personagens durante o governo joanino. Particularmente em relação à ida da Coroa portuguesa para a América, as posições também eram díspares. Enquanto para D. Rodrigo a criação de um grande Império no Brasil era a melhor forma de defender a sustentação do Império Português, para Antônio de Araújo a partida só se faria em caso de extrema necessidade, isto é, diante da inevitabilidade da guerra com a França ${ }^{51}$ Ademais, nesse contexto de acirradas disputas ideológicas, as correspondências políticas dos ministros reais mantêm uma lógica discursiva própria de um tipo de cultura diplomáti$\mathrm{ca}^{52}$ do período, cujo principal interlocutor era o rei: convencê-lo da viabilidade de seus projetos era a disputa principal que movia esses homens de Estado.

Da mesma forma que Hipólito fazia uma crítica veemente a Araújo, este também ressaltava a máxima probidade de D. Rodrigo de Souza Coutinho. "S.A.R. não tem a seu serviço nenhum Ministro mais inteligente, nem mais desinteressado do que D. Rodrigo; e de seu patriotismo não quero outra prova senão o De-

\footnotetext{
50 Ibid.

51 PEDREIRA, Jorge; COSTA, Fernando Dores. D. João VI... Op. Cit., p. 183.

52 Utilizamos aqui o conceito de cultura diplomática defendido pelo historiador Diogo Ramada Curto. Segundo o autor, a "maneira de pensar a política em função das acções de personagens concretas não diz apenas respeito à esfera das relações diplomáticas [...]. Trata-se, aliás, do resultado de hábitos de escrita que implicam a capacidade de observar e descrever outras unidades políticas, que tanto podem incluir uma sistematização por temas, como por personagens ou facções. A par destas práticas de escritas de cartas, ofícios e relatórios, será necessário considerar hábitos de leitura bastante enraizados, tanto no que respeita jornais e gazetas, como no que concerne à obras de referência." CURTO, Diogo Ramada. "D. Rodrigo e a Casa Literária do Arco do Cego". In: Cultura Escrita. Lisboa: ICS, Imprensa de Ciências Sociais, 2007. p. 249-250. Para a análise pormenorizada do conceito, ver p. 248-261.
} 
creto que acabei de transcrever", referindo-se à notícia de que a Impressão Régia do Rio de Janeiro estava apta para imprimir toda e qualquer obra, além de ter as portas abertas à contratação de aprendizes nas diversas áreas da impressão. ${ }^{53}$ Muito possivelmente, o elogio ao ministro real se deve aos antigos laços de amizade e admiração que os uniam, quando Hipólito ainda servia diretamente à monarquia portuguesa. Esse fato, entretanto, não o impediu de tecer rígidas críticas ao comportamento de D. Rodrigo de Souza Coutinho na estruturação do governo Português no Brasil. Em 1802, D. Rodrigo prometia a Hipólito cessar a perseguição aos maçons, tendo para isso a posterior anuência do Príncipe Regente. ${ }^{54}$ Como sabemos, a promessa não se cumpriu e Hipólito foi preso pela inquisição portuguesa, tendo chegado a Londres depois do sucesso da sua fuga, apoiada pelos irmãos da ordem.

A réplica à acusação de traição foi escrita provavelmente pelo próprio Araújo, que assinou com o pseudônimo Amigo da Justiça, em fevereiro de 1809. A íntegra da defesa foi publicada em 1810 sob o título Provas da Falsidade, e Injustiça com que o editor do Correio Braziliense intentou desacreditar Antonio de Araújo Azevedo e algumas reflexões acerca desse jornal oferecidas aos seus leitores. Nesta contestação, o autor rememorava a sua proposta de enviar D. Pedro de Alcântara para o Brasil, além do muito desvelo que tivera na organização e no aumento do exército português, mesmo quando muitos eram contrários à ideia. ${ }^{55}$

\footnotetext{
53 Obviamente, o Decreto real fazia alusão à alta qualidade técnica da tipografia brasileira e não a livre publicação dos conteúdos dos livros.

${ }^{54}$ Cf. VILLALTA, Luiz. "Libertinagens... Op. Cit., p. 548.

55 Amigo da Justiça. Provas da Falsidade, e Injustiça com que o editor do Correio Braziliense intentou desacreditar Antonio de Araujo Azevedo e algumas reflexões acerca desse jornal oferecidas aos seus leitores, Lisboa: Nova Oficina de João Rodrigues Neves, 1810, p. 19. Com Licença da Mesa do Desembargo do Paço. "[...] a publicidade [do projeto político de trazer D. Pedro para o Brasil] foi tal, que até se imprimiu uma Proclamação feita por S.A.R. aos povos do Brasil”, afirmava o
} 
Com isso, Araújo tentava provar sua lealdade e inocência, já que sua intenção era salvaguardar a integridade da monarquia portuguesa. ${ }^{56}$ Por fim, o interlocutor centrava suas críticas na personalidade do editor do Correio que, segundo ele, era "obrigado a fazer o papel de Caturra Literato para subsistir". ${ }^{57}$ Para além de qualificá-lo de caturra - bobo, chocarreiro, aquele que se metia sempre em encrencas, sendo digno de escárnio ${ }^{58}$ - ainda o acusava de ter-se corrompido:

Seja-me lícito fazê-lo certo, de que é chegado o tempo em que os Leitores do seu jornal devem saber que as indignas linhas lançadas a pag.519, do I. ${ }^{\circ}$ vol. não foram suscitadas como ele pretende inculcar, pelo rumor que corria em algumas das gazetas Inglesas, foram sim movidas pela força de quatrocentas libras esterlinas, a que sua alma fraca, e venal não pode resistir!.. Tenha ele igualmente a certeza, de que, assim, no Brasil, como em Portugal, se fala já e não pouco deste seu torpe procedimento. ${ }^{59}$

Por muitas vezes, Hipólito foi acusado de "vender sua pena”. As negociações entre o jornalista e o embaixador português em

autor (p. 7). Este decreto assinado por D. João se encontra na Seção de Manuscritos da BNRJ sob o título Decreto de S.AR. para se publicar no Brasil quando chegasse o Príncipe Menino àquele Estado, com a data de 2 de outubro de 1807. (Mss. I,9,11,15, n004).

56 "A insistência de Araújo de Azevedo na partida de D. Pedro correspondia afinal à ideia de que ainda seria possível evitar a invasão, por meio da satisfação do essencial das injunções com a França. Assim, se salvaguardaria a soberania sobre o Brasil, facultando, ao mesmo tempo, os ingleses a faculdade de encontrarem na eventual abertura de um outro porto brasileiro uma compensação pelas perdas suportadas pelo seu comércio como resultado do encerramento dos portos de Portugal." PEDREIRA, Jorge; COSTA, Fernando Dores. D. João VI... Op. Cit., p. 166.

57 Amigo da Justiça. Provas da Falsidade... Op. Cit., p. 19 (Grifos do Original).

58 SILVA, Antonio de Moraes. Diccionário de Língua Portuguesa Recopilado, Tipographia Lacerdina, 1813. VERBETES: CATURRA, p. 362, v.1.

59 Amigo da Justiça. Provas da Falsidade... Op. Cit., p. 13. 
Londres, D. Domingos de Souza Coutinho foram sempre muito tensas, sendo imprescindíveis algumas intermediações, como a de Vicente Pedro Nolasco da Cunha, ou mesmo o Duque de Sussex. Já com o Príncipe Regente, o acordo acerca das "conveniências materiais do jornal" foi secretíssimo e também necessitou de um intermediário: Heliodoro Carneiro, médico da câmara de D. João e amigo particular do redator, que foi de Londres ao Rio de Janeiro resolver a questão da manutenção da folha, em meados de 1812. Na Corte, o médico encontrou o Príncipe Regente muito insatisfeito com o jornal.

Contextualiza Mecenas Dourado: ${ }^{60}$

[...] As críticas acerbas à administração do intendente de Polícia continuavam, e os ataques ao Conde de Funchal como aos governadores do reino e de certas capitanias do Brasil, ocupavam, sem cessar, as páginas do Correio Braziliense. D. João estava disposto, assim, a fazê-lo mudar de linguagem ou acabá-lo 'custasse o que custasse'.

Segundo as palavras do próprio Heliodoro Carneiro, D. João fizera-o "criatura sua". ${ }^{61}$ Assim, tendo a conduta de vassalo fiel "à calada, e sem os Ministros d'Estado saberem o auctor"62, informava-o diretamente da situação política "por que via cá por fora a opinião pública e o estado da Europa, e nunca quis [lhe] enganar." ${ }^{63}$ Em outras palavras, o Príncipe exigia uma mudança na linha editorial do Correio Braziliense e para isso propôs um pacto vantajoso a ambas as partes.

\footnotetext{
${ }^{60}$ DOURADO, Mecenas. Hipólito... Op. Cit., t. II, p. 388.

${ }^{61}$ CARNEIRO, Heliodoro. Cartas dirigidas a S. M. el-rei D. João VI desde 1817: A cerca do estado de Portugal e Brazil, e outros mais documentos escritos Imprenta Londres : Impreçaô de Mess. Cox e Baylis, [1821], p. 41.

${ }^{62}$ Ibid., p. 40

${ }^{63}$ Ibid., p. 58.
} 
De caráter secretíssimo, o acordo de subvenção do Correio sairia dos cofres da repartição da Intendência Geral da Polícia do Rio de Janeiro e custaria ao governo joanino a significativa quantia de $£ 2.000$ (duas mil libras) anuais. Hipólito solicitava o pagamento antecipado da primeira parcela do acordo para garantir o mesmo "tratamento" recebido pelo Investigador Portuguez em Inglaterra, jornal financiado pela Coroa que circulava em Londres desde meados de 1811. A aliança secreta foi firmada e durou até 1821, quando D. João VI regressou a Portugal. ${ }^{64}$

De Londres, em agosto de 1814, Heliodoro Carneiro explicava a Paulo Fernandes Viana o porquê da demora na remessa dos exemplares do Correio para o Brasil:

Não tem havido navio algum para essa cidade [Rio], e por isso se ajuntaram aqui os números de abril, maio, junho e julho: e no momento que se foram despachar para irem no [][sic] navio português $D$. Rodrigo foram tomados pela Alfândega, dando por pretexto que valiam mais do que aquilo em que eram avaliados, porquanto deve saber V.S. que sempre se dá e determina o valor ao que se despacha para deste valor receber o governo seis por cento. ${ }^{65}$

Para além de apontar as vantagens financeiras governamentais, o médico também advertia sobre a queda no número de subscritores depois da "mudança de linguagem":

Dizendo mais a V.S. que Hipólito tem perdido muito subscritor do jornal depois que tem seguido e tomado

\footnotetext{
${ }^{64}$ DOURADO, Mecenas. Hipólito... Op. Cit., t.II, p. 396.

${ }^{65}$ Carta Autografa de Heliodoro Carneiro, de 17 de agosto de 1814, remetida ao Intendente Geral da Polícia nos seguintes termos: "Ilmo. Sr. ${ }^{\circ}$ Paulo Fernandes Viana, do Conselho de S.A.R. o Príncipe Regente. Rio de Janeiro”. Coleção Particular Dr. Marcos de Mendonça. Apud, DOURADO, Mecenas. Hipólito... Op. Cit., t.II, p. 396 (Grifo nosso).
} 
outra linguagem no seu jornal: o que eu sei e o que me tem alegado muitas vezes o Hipólito para me fazer ver os seus serviços e sacrifícios. ${ }^{66}$

Esta transação, portanto, ficou circunscrita da seguinte maneira: no Rio de Janeiro, D. João confiou a Paulo Fernandes Viana a tarefa de receber as "correspondências privadas" ${ }^{67}$ vindas de Hipólito. De Londres, Heliodoro Carneiro intermediava secretamente as possíveis divergências políticas entre o Príncipe e o jornalista. Aos embaixadores portugueses em Londres, sobretudo, era vedada a hipótese de qualquer conhecimento sobre essa aliança. Ao final de 1815, Funchal informava D. João dos constantes boatos sobre o pagamento da atividade jornalística do redator do Correio, o que bem demonstra o seu desconhecimento do acordo. "É voz pública nesta cidade [Londres] que para esse fim recebe 4 ou 5 mil cruzados". ${ }^{68}$ Segundo o historiador Luís Munaro,

Ainda que Hipólito da Costa esteja vinculado à monarquia através de uma relação ela mesma clientelar - seu Correio Braziliense é subvencionado ao rei D. João VI através do intendente de polícia Paulo Fernandes Viana -, o jornalista não se furta a denunciar a urgência das reformas administrativas, nomeando nas decisões oficiais aquilo que julga incoerente com as 'luzes do século. ${ }^{69}$

Para o autor, Hipólito fazia parte de um momento de transição política em que a própria imprensa estava situada "entre formas tradicionais de mecenato e o incentivo de comerciantes

\footnotetext{
${ }^{66}$ Ibid., t.II, p. 396.

67 Expressão utilizada pelo próprio Intendente da Polícia, Paulo Fernandes, para referir-se a tais correspondências. [Para maiores informações, ver Dicionário Biobibliográfico Português Francisco Inocencio da Silva, tomo X, p. 383-385.]

68 BNRJ. Seção de Manuscritos. I - 29,18,1, n² . Coleção Linhares.

${ }^{69}$ MUNARO, Luís. "A unidade do Reino luso-brasileiro... Op. Cit., p. 4-5.
} 
empolgados com a ideia de montar um club em Londres". ${ }^{70}$ Para além da capital britânica, o apoio financeiro de autoridades políticas brasileiras também despertava a desconfiança dos contemporâneos. Em fevereiro de 1821 - no auge do movimento constitucional - D. José Luís de Sousa comentava a questão.

[...] o que nesta matéria faz requintar a desordem ao último ponto é crer-se geralmente que uma das autoridades do Rio de Janeiro tem a seu soldo o Correio Braziliense e que se serve daquele jornal para caluniar e injuriar descarada e impunemente pessoas que ocupam os mais altos empregos e que Sua Majestade honra com sua confiança... Se há, pois, uma autoridade que pague este jornal tem atraiçoado os interesses de Sua Majestade e da monarquia. $^{71}$

A participação real nesta transação confirmar-se-ia anos mais tarde, em 1826, data da morte de D. João VI. Por essa época, em uma conversa com o Conde de Barbacena, Heliodoro Carneiro ainda tentava amenizar as funestas consequências políticas advindas da publicação das cartas que enviou a El Rei entre 1817 e $1821 .^{72}$ Nesse episódio, o médico relembrou uma importante ocorrência de 1821, referente à intermediação que fazia entre Hipólito e D. João VI. Vejamos:

[...] Depois de ele divagar muito contra o Senhor Infante, teve a fraqueza de me ler, e mostrar a parte que levava escrita a El Rei a respeito do meu negócio, isto é, que eu

\footnotetext{
${ }^{70}$ Ibid., p. 4-5.

71 Arquivo Histórico do Itamarati. Legação de Londres. Correspondência ostensiva e reservada a D. Luís de Sousa.

${ }^{72}$ CARNEIRO, Heliodoro Jacinto de Araújo. Exposição resumida do que durante os dezoito mezes que estive em Lisboa soffri à facção e os acelerados que dominavam el-rei e o levaram à sepultura. Pariz: Officina Typ. de Paulo Renourd, 1826.
} 
produzia uns recibos de Hipólito José da Costa em uns bocados de papel, e sem serem reconhecidos pelo Cônsul Inglês. $^{73}$

Para além de Carneiro assumir a sua posição de intermediador no negócio entre a Coroa e o Correio Braziliense, ainda exaltava a sua indignação diante da atitude considerada desrespeitosa dos Condes de Barbacena e Porto-Santo; fato que o fez recorrer diretamente a D. João VI. Sua descrição é reveladora:

[...] Saí dali, e quase sem saber o que fazia, fui direto à Ajuda, onde se achava El Rei; mas achando-o então na Capela, assistindo a festa do Espírito Santo, deixei isto para o primeiro dia de audiência, que era sexta-feira, em cujo dia fui à Bemposta [sic], e disse a S.M "Que o Conde de Porto-Santo não só estava conluiado com os meus inimigos, mas até se servia agora de chicanas as mais pueris e ridículas para se opor ao pagamento daquilo que S.M. Tinha Mandado pagar, e que melhor que ninguém Sabia dever-me; que S.M conhecia muito bem a letra de Hipólito, $e$ até ele Conde, pois pertencia a mesma súcia; que a primeira coisa que S.M. me tinha recomendado na transação com Hipólito, e nas outras, era segredo absoluto; portanto, como havia eu de fazer pública uma coisa tal, mostrando ao Cônsul Inglês? Que em quanto a serem [sic] os recibos passados em pequenas porções de papel, isso nada mudava a essência do recibo, pois consistia a sua validade na grandeza do papel. ${ }^{74}$

A despeito da importância de Heliodoro Carneiro nessa negociata, notamos que as grandes vantagens dessa transação foram restritas às autoridades diretamente interessadas: D. João VI e Hipólito da Costa. Durante todo o período joanino, o jornalista

${ }^{73}$ Ibid., p. 40.

74 Ibid., p. 40. 
fez críticas diretas aos principais homens de confiança do monarca. Todos estavam sob a sua lupa: ministros, diplomatas, governadores do Reino e intendentes da polícia. Nesse sentido, suas ponderações e críticas eram uma parte essencial no olhar que D. João teceria sobre seus súditos mais influentes; aqueles que compunham a órbita real e atuavam diretamente na sustentação do Império Português. Observá-los por uma análise externa lhe dava a chance de vê-los mais detalhadamente e, portanto, melhor conduzir as intrigas políticas inerentes ao seu governo: toda essa sigilosa estratégia é parte significativa da política cultural da Coroa Portuguesa no universo da imprensa interatlântica. Por esta ótica, Hipólito também atuava como um orientador político indispensável do próprio D. João, que astutamente sabia se aproveitar de um olhar iluminado, advindo da Inglaterra, berço do liberalismo onde vigorava a liberdade de imprensa desde 1695.

\subsection{O Investigador Portuguez em Inglaterra e a disputa com o Correio Braziliense}

A primeira edição do Correio Braziliense já marcava a posição de Hipólito da Costa no novo cenário que se delineava na imprensa periódica da imigração acerca do universo luso-brasileiro: no diálogo com os leitores esclarecia seus objetivos políticos, como também balizava as principais temáticas que permeariam as páginas do jornal. Dizia o escritor:

O primeiro dever do homem em sociedade é ser útil aos membros dela; e cada um deve, segundo as suas forças Físicas, ou Morais, administrar, em benefício da mesma, os conhecimementos, ou talentos, que a natureza, a arte, ou a educação lhe prestou [...] Longe de imitar só, o primeiro 
despertador da opinião pública nos fatos, que excitam a curiosidade dos povos, quero além disso, traçar as melhorias das Ciências, das artes, e numa palavra, de tudo aquilo que pode ser útil à sociedade em geral. ${ }^{75}$

Neste discurso inaugural, as melhorias da ciência e da arte já apareciam como assuntos prioritários do redator, que as considerava campos do conhecimento de suprema utilidade para o progresso da sociedade. ${ }^{76}$ Enquanto a ciência teve espaço garantido prioritariamente na seção "Literatura e Ciências" (onde o jornalista debatia os mais variados temas de interesse para a cultura científica), a discussão sobre as artes esteve circunscrita ao espaço denominado "Comércio e Artes", dois ramos ainda muito próximos entre o final do século XVIII e início do XIX, como atesta o historiador João Luís Lisboa. Nas palavras do pesquisador,

Entende-se então "arte" não no seu exclusivo sentido estético de "belas-artes" que o século XIX consagrou, mas como "habilidade", "técnica", "produção", "arte manual" ou "indústria". Esta limitação no sentido de "arte" [...] tem claramente a ver com a automização e com o ganhar corpo da noção de ciência como saber teórico estruturado e com o alargamento da economia manufatureira. ${ }^{77}$

As reflexões do jornalista no campo das artes ou da ciência eram compreendidas como um meio privilegiado de propagação das luzes para o avanço do progresso. Segundo Alberto Dines, o Correio era "mais do que um projeto jornalístico, [era] uma revolução cultural" sendo a "literatura tomada no sentido mais amplo,

${ }^{75}$ Correio Braziliense, N. I, Introducção, p. 3-4.

76 Tal era o foco, que o jornal era estruturado em quatro seções: "Política", "Miscelânia", "Comércio e Artes" e "Literatura e Ciências".

77 LISBOA, João Luís. Op. Cit., p. 91 (Grifo nosso) 
o conteúdo dos livros - as ideias"78; que na prática englobavam a universalidade dos campos dos conhecimentos do Homem.

Como já dissemos, para Hipólito, a liberdade de pensamento era condição sine qua non no aprimoramento do saber, considerado a base para a constituição de uma sociedade livre: pôr em vigor a autonomia das instituições de ensino, como as Universidades e Academias era medida imprescindível para o progresso espiritual. ${ }^{79}$ Ao defender valores caros aos homens do iluminismo, em outubro de 1808, a censura do governo português nos diferentes ramos de produção, sobretudo literária e científica, foi alvo de suas críticas:

[...] a nação portuguesa tem muitos homens de talentos, e alguns de erudição, e conhecimentos; somente disse que os entraves, que se põem às ciências, às perseguições, que sofrem os homens de letras, e outras causas que atribuo ao Governo, fazem com que esses talentos estejam sopitados [sic], e que não haja, nem possa haver, produções literárias. ${ }^{80}$

Não podemos esquecer que, entre 1800 e 1802, Hipólito ocupou dois cargos de grande responsabilidade: fez parte da equipe editorial da Casa Literária do Arco do Cego (1799-1801), dirigida pelo frei Mariano da Conceição Veloso ${ }^{81}$, e também atuou como diretor literário da Impressão Régia, em 1802, "lugar

78 DINES, Alberto. “O patrono e o seu modelo.” In: Dines e Isabel Lustosa. (Org.). Correio Braziliense. São Paulo: Imprensa Oficial do Estado de São Paulo/UNIEMP/Correio Brasiliense, 2001, v. 1, p. xxvii-xxviii.

79 OLIVERIA, José Carlos. "Os periódicos portugueses de Inglaterra e a Cultura Científica Brasileira (1808-1821)”. Revista da SBHC, n.19, 1998, p. 35-37.

${ }^{80} \mathrm{CB}$, Vol. I, p. 383 (Grifos nossos).

${ }^{81}$ Sobre a vigência da Casa Literária do Arco do Cego ver: CURTO, Diogo Ramada. "D. Rodrigo e a Casa Literária do Arco do Cego". In: Cultura Escrita... Op. Cit., p. 239-280; LYRA, Maria de Lourdes. A utopia.... Op. Cit., p. 83-88. 
que exerceria com empenho e dedicação e no exercício do qual procuraria dar continuidade ao projeto anteriormente assumido, traduzindo para edição algumas obras de caráter técnico e econômico, entre as quais os Ensaios Económicos e Filosóficos, de Benjamin Rumford". ${ }^{82}$ Detalhe: em ambos os cargos, Hipólito esteve imerso na lógica de um complexo sistema de censura, conhecendo todos os seus trâmites por dentro, inclusive com a atuação da Inquisição e da Polícia. ${ }^{83}$ Porém, a vivência nos Estados Unidos da prática da liberdade de imprensa o colocava diante de um dilema: a realização de seu trabalho como homem de imprensa em Portugal - como a tradução e a seleção de textos para publicação - não era livre; diferentemente do que acontecia na Inglaterra, onde tinha total liberdade para escrever e, assim, ressaltar os prejuízos da prática da censura exercida por homens escolhidos pela Coroa portuguesa. Para ele, a censura era "um absurdo, só por si, capaz de aniquilar inteiramente o gênio de uma nação" ${ }^{84}$ Segundo a avaliação da historiadora Ana Cristina Araújo, em relação às diretrizes e problemas intrínsecos à prática do pensamento ilustrado em Portugal no final do século XVIII,

[...] a polêmica e o confronto entre dois mundos culturais se travou na fronteira entre a ordem pública e privada, a meio caminho entre o usufruto das letras e o domínio das regras de utilização da palavra. No que concerne à utilização da mensagem escrita, as várias fases que o livro percorre, produção, aprovação e difusão, concitam a análise prévia da relação triangular do autor (tradutor), editor, censor. ${ }^{85}$

82 PEDROSA, Alcino. “Trajetória Biográfica.... Op. Cit., p. 18 (Grifo do original).

${ }^{83}$ CB, Vol. I, p. 384.

${ }^{84}$ Ibid., p. 383.

${ }^{85}$ ARAÚJO, Ana Cristina, A cultura das Luzes em Portugal: temas e problemas. Lisboa: Livros Horizontes, 2003, p. 11 
Sob a ótica das Luzes e a maçônica, Hipólito da Costa desenvolveu a sua visão de progresso, intrínseca à ideia da necessidade de cada um "superar os seus "vícios", ou seja, os fanatismos, as tiranias, as supertições e a ignorância" " 86 ; compreendidos como um retrocesso que deveria ser evitado a todo custo, se Portugal realmente desejasse andar em compasso com os valores da Europa civilizada. ${ }^{87}$ E Hipólito considerava que muitos "vícios" ainda estavam fortemente presentes no governo português. A perseguição aos franco-maçons e também o incentivo da Coroa às obras antimaçônicas, como Os Pedreiros Livres e os Iluminados, Que mais propriamente se deverião denominar os Tenebrosos, De cujas seitas se tem formado a pestilencial Irmandade, a que hoje se chama Jacobinismo ${ }^{88}$, eram, na prática, manifestações dessa ignorância.

Posto isso, entre agosto e setembro de 1809, o redator respondia ao conteúdo considerado incidioso dessa publicação:

As acusações, e perseguições contra os Franco-maçons têm seguido estes passos de todas as outras; porque sendo fundadas na ignorância, acabaram já em Inglaterra, e em todos os demais países, onde as ciências têm feito progressos, e assim em Portugal, será talvez a última parte onde estas perseguições acabem; porque o atraso naquela infeliz nação é tão proverbial na Europa, que se julga andarem os portugueses três séculos atrás das demais nações. ${ }^{89}$

Como agente civilizador, portanto, o jornalista desnudava problemáticas políticas espinhosas da monarquia portuguesa e

${ }^{86}$ BARATA, Alexandre Mansur. Maçonaria... Op. Cit., p. 118 (Grifo nosso).

${ }^{87} \mathrm{CB}$, Vol. III, p. 146.

${ }^{88}$ A obra publicada pela Impressão Régia do Rio de Janeiro em 1809, sendo vendida na loja do livreiro Paulo Martins Filho.

${ }^{89}$ CB, Vol. III, p. 146 
abria um espaço poderoso de debate e formação da opinião pública. De acordo com o historiador português José Alves, opinião pública na época era concebida como "o resultado deste debate político e desta discussão pública, radicados no conceito de autoridade debatida, cuja base é a esperança de que a verdade e a justiça surgirão da sociedade constituída como um grande organismo de livre e pública discussão".90

Desde a decisão da partida da Corte para o Brasil, a atuação de D. Domingos de Souza Coutinho (Conde de Funchal) na política externa portuguesa ganhava relevo. ${ }^{91}$ Mesmo sem o consentimento do Príncipe, durante a viagem da família real para a América, o embaixador português em Londres assumiu plenamente a representação diplomática do país. Com a constituição do governo no Rio de Janeiro, sua influência política seria intermediada por d. Rodrigo - seu irmão - e por Lord Strangford, ministro plenipotenciário inglês. ${ }^{92}$ Apesar de ter sua ação limitada

\footnotetext{
${ }^{90}$ ALVES, José Augusto dos Santos. A opinião... Op. Cit., p. 26 (Grifo nosso).

${ }^{91}$ D. Domingos António de Sousa Coutinho (1760-1833), formado em Leis, seguiu a carreira diplomática, tendo ocupado os cargos de enviado na Dinamarca (1790-1795), representante de Portugal em Turim (1796-1803) embaixador em Londres (1803-1814) e em Roma (1814-1828). Em 1810 foi governador do Reino de Portugal. Foi-lhe concedido o título de Conde do Funchal em 17 de Dezembro de 1808, tendo sido elevado a Marquês em Junho de 1833, pouco tempo antes do seu falecimento. Foi autor de numerosos escritos políticos e diplomáticos. Disponível em: www.aatt.org. Acesso em: 12 de julho de 2010. Para informações mais detalhas sobre o diplomata, ver MACHADO, Adelaide Maria Muralha Vieira. "Domingos António de Sousa Coutinho (1760-1833) $1^{\circ}$ Conde e Marquês de Funchal. Pensamento e acção". In: Congresso Histórico 98. Amarante: 1998. p. 471-481; COUTINHO, Domingos António de Sousa $1^{\circ}$ Conde e Marquês de Funchal (1760-1833). In: Dicionário do Vintismo e do Primeiro Cartismo (1821-1823 e 1836-1828). Lisboa: Edições Afrontamento, Vol. I, 2002. p. 534-545.

92 Percy Clinton Sydney Smythe. Lorde Strangford. (1780-1855). Nobre inglês, Strangford foi embaixador britânico junto à Corte de D. João, primeiro em Lisboa, depois no Rio de Janeiro. Com pouco mais de vinte anos, já era funcionário
} 
por outros agentes políticos, Funchal seria responsável por um importante projeto da política impressa da Coroa: em 1811, tinha sob suas mãos a direção d'O Investigador Portuguez em Inglaterra.

A primeira edição d' O Investigador Portuguez em Inglaterra saiu em julho de 1811. Redigido em Londres, O Investigador tinha o intuito de combater a ressonância dos ideais políticos de independência do Brasil presentes no Correio Braziliense que ecoavam nos dois lados do Atlântico, sendo o resultado de um projeto explicitamente apoiado e patrocinado pela Coroa Portuguesa. ${ }^{93}$ Entre os anos de 1811 e 1814, o periódico teve como redatores os médicos portugueses Bernardo José de Abrantes e Castro e Vicente Pedro Nolasco da Cunha, ambos exilados na Inglaterra. A partir 1814, Abrantes e Castro foi substituído por José Liberato Freire de Carvalho na redação, onde permaneceu até 1819, quando a folha deixou de circular. ${ }^{94}$

do Ministério dos Negócios Estrangeiros da Inglaterra, atuando como secretário da missão diplomática em Lisboa. Defensor acérrimo dos interesses britânicos, nas palavras de Patrick Wilson, tornou-se embaixador às vésperas da partida da Corte portuguesa para o Brasil. No Rio de Janeiro, foi um dos principais estrategistas para a assinatura do Tratado de 1810, que concedia amplos privilégios comercias à Inglaterra. A impopularidade do ministro, entretanto, era imensa; sendo por muito tempo considerado o símbolo do poder imperial britânico sobre D. João. VAINFAS, Ronaldo. In: NEVES, Lúcia Bastos Pereira das; VAINFAS, Ronaldo (Org.). Dicionário do Brasil joanino... Op. Cit., p. 369-370.

${ }_{93}$ Segundo Adelaide Machado, "A mensagem política não diferia tanto quanto os polemistas de ambos os jornais queriam fazer querer, no essencial, e para este período, era até a mesma: moderada e lutando pela reforma do abuso, baseava-se na admiração pelo modelo inglês." MACHADO, Adelaide Maria Muralha Vieira. O Investigador Português em Inglaterra, Jornal Literário, Político. \& C., nos primeiros anos de publicação (1811-1813). Lisboa: UNL/CLC, 1998. p. 474.

94 MACHADO, Adelaide Maria Muralha Vieira. O Investigador Portuguez em Inglaterra, Jornal Literário, Político. \& C., nos primeiros anos de publicação (1811-1813). Dissertação de Mestrado. Universidade Nova de Lisboa, 1996. p. 7. Sobre a problemática acerca da segunda fase d'O Investigador Portuguez, sobretudo referente à atuação do redator José Liberato Freire de Carvalho, ver: BOISVERT, Georges. "La presse périodique portugaise de Londres. Notes sur les 
Um Jornal escrito na Língua Portuguesa [...] apresenta notícias gerais de Literatura e Ciências, e dos progressos que as mesmas vão fazendo neste Reino, e nas mais partes da Europa, (com a brevidade, que as circustâncias da Guerra permitirem), não só parece recomendável, mas até de suma necessidade.

Mudanças extraordinárias, nova ordem nas públicas ocorrências requerem do Filósofo, e do Estadista, uma profunda investigação sobre a origem, condição e autenticidade dos fatos, assim como uma judicosa censura, e imparcialidade ingênua na sua exposição. [...]. ${ }^{95}$

Publicado no "Prospecto" do jornal, o primeiro discurso exaltava o português como língua nacional, já na tentativa de circunscrever suas peculiaridades e possíveis diferenças com o Correio Braziliense, que desde a edição de estreia criticava a pequena produção literária em língua portuguesa em um país de homens com grande capacidade literária que poderiam dar vivacidade à literatura, se não fosse as "constantes perseguições, que naquele país sofrem os homens de letras". ${ }^{96}$ Era justamente contra tal ideia que $O$ Investigador tentava contrapor-se. Para além de elevar a língua e a identidade nacional através da literatura, concebendo-a como um elo de união entre os vassalos da monarquia portuguesa, também seus redatores tinham claro que tanto a literatura portuguesa quanto as ciências europeias eram consideradas pilares fundamentais na delimitação do seu espaço

circonstances de son apparition et de son développement." Sillages. Sus la direction de R.A. Lawton. N. 4. (1974). Poitiers: Département d'Études Portugaises et Brésiliennes de l'Université de Poitiers, 1974. p. 69-88; BOISVERT, Georges. "Le comte de Palmela et la presse potugaise libre (1816-1820) d’aprés des documents diplomatiques inédites." Arquivo do Centro Cultural Português. Paris: Fundação Calouste Gulbenkian/Centro Cultural Português, 1982. p. 459-509.

95 O Investigador Portuguez em Inglaterra, N.I, Prospecto, p. 1-2.

${ }^{96}$ CB, Vol. I, p. 30 
de intervenção política enquanto agentes históricos responsáveis pelo esclarecimento na trilha do progresso. Particularmente em relação à poesia, defendiam a sua utilidade à pátria e ao Estado, vangloriando poetas consagrados como Luiz de Camões, cuja obra enaltecia a grandeza da nação. Eis o discurso do jornal em julho de 1813:

Quem tem concorrido mais que a poesia para a civilização e melhoramento das nações? A fábula que representa a lira de Orpheu arrancando os rochedos pela melodia de seus acentos é o emblema de uma verdade reconhecida; o influxo da poesia na agricultura e na moral. ${ }^{97}$

A poesia como orgulho patriótico. Símbolo máximo do alto grau de civilização. Força inalienável cujo mérito no aperfeiçoamento moral da sociedade também se estendia para o reconhecimento, valorização e aprimoramento da agricultura, concebida como o principal meio de o país conquistar a liberdade e a independência econômica e política. ${ }^{98}$ Tal proposição é confirmada na Carta Régia, de 7 de março de 1810. Neste documento, D. João "apontava a agricultura como atividade em que o país devia basear o seu desenvolvimento e a sua participação, num mundo cada vez mais permeado pelas trocas internacionais." ${ }^{99}$ De inspiração de d. Rodrigo de Souza Coutinho, o programa sugerido pela Coroa propunha a reforma do regime senhorial agrícola, apoiando novas formas institucionais mais modernas da posse da terra. Com a morte do ministro e pouco apoio dos governadores do Reino, o programa acabou por não ser executado.

97 IP, Vol. VII, p. 86.

98 Artigo "Estabelecimento da Sociedade da Agricultura”. Idem, p. 84.

99 PEDREIRA, Jorge; COSTA, Fernando Dores. D. João VI... Op. Cit., p. 282. 
Estas medidas faziam ainda mais sentido se compreendermos que desde o início do século XVIII, o sistema de alianças entre as potências europeias colocava Portugal alinhado à Coroa britânica, numa clara situação de desvantagem. Desta constatação, interessa-nos ressaltar a proteção inglesa à navegação Atlântica, que durante todo esse período garantiu a comunicação entre os portos portugueses e brasileiros, e o pioneirismo inglês na revolução industrial. ${ }^{100}$ Já no início do século XIX, em meio às guerras napoleônicas, escancaravam-se ainda mais a dependência política, econômica e militar de Portugal em relação à Inglaterra. Para além da proteção britânica aos navios portugueses no processo de transladação da família real para o Brasil, o Tratado de 1810 selava as vantagens econômicas da Coroa inglesa no comércio anglo-luso-brasileiro. Isso sem contarmos com a presença do exército inglês em Portugal entre os anos de 1808 e 1821, simbolizado na constante presença de Lord Beresford. Para o historiador Valentim Alexandre, a abertura portuguesa às negociações do tratado de comércio pode ser lida como a garantia dada pela Grã-Bretanha de que a legitimidade da monarquia bragantina estaria assegurada em solo português. ${ }^{101}$

100 "A Grã-Bretanha [...] possuía uma economia bastante forte e um Estado suficientemente agressivo para conquistar os mercados de seus competidores. De fato, as guerras de 1738-1815, a última e decisiva fase do duelo secular anglo-francês, virtualmente eliminaram do mundo não-europeu todos os rivais dos britânicos, exceto até certo ponto os jovens EUA. Além do mais a Grã-Bretanha possuía uma indústria admiravelmente ajustada à revolução industrial pioneira sob condições capitalistas e uma conjuntura econômica que permitia que se lançasse à indústria algodoeira à expansão colonial. A indústria algodoeira britânica, como todas as outras indústrias algodoeiras, tinha originalmente se desenvolvido como um subproduto do comércio ultramarino." HOBSBAWM. Eric. A era das revoluções... Op. Cit., p. 49.

101 ALEXANDRE, Valentim. Os sentidos do Império. Questão nacional e questão colonial na crise do antigo regime português. Porto: Afrontamento, 1993. p. 210. 
Em meados de 1813, o Visconde da Lapa - sócio da Academia Real das Ciências de Lisboa -, produzia o documento Ideias Gerais sobre a Polícia, muito provavelmente a pedido da Coroa. ${ }^{102}$ Ao pensar um novo paradigma para a instituição policial na cidade sob a perspectiva imperial ${ }^{103}$, o autor evidenciava a relação entre o bem geral do Estado e a administração do espaço urbano pela polícia. Sobre isso, refletia:

O conhecimento do todo [da cidade], e de cada uma das suas partes, é indispensável, e sem isso, não é possível estabelecer salutíferas [sic] ativas providências. A ciência da polícia consiste em adotar no estado atual de qualquer Nação ou Império, aquelas prudentes medidas, que mais concorram para conservar e aumentar a fortuna do Estado, na sua constituição interior, e no seu progresso sucessivo em todas as partes. Deve ser o princípio geral da Polícia, dar tal tendência a este ente constitucional político, que se conserve e aumente o bem do Estado. ${ }^{104}$

Durante o Século das Luzes, a cidade teve uma importância capital: neste espaço, as ideias circulavam e a prática política da crítica ao status quo se fazia presente. ${ }^{105}$ Essas mudanças na transformação do olhar dos homens para a cidade puderam ser

102 O manuscrito é datado de fevereiro de 1813.

103 Nos itens 19 e 20 deste manuscrito, o autor define a cidade como "uma agregação de sociedades, famílias e pessoas que vivem juntos [sic] debaixo de uma certa vigia da polícia, para com mais comodidade e proveito, promoverem, certos ofícios, e meios de subsistência, necessários ao bem e aumento do país. 20. Quanto maiores e florescentes forem as cidades de um país, tanto melhor se cuidará do todo." BNP. Res., Mss. 246, n. 28. [Ofício de 28 de Setembro de 1820 para o $1^{\circ}$ Conde da Lapa, Manuel de Almeida e Vasconcelos, ministro plenipotenciário na Corte da Rússia] (Grifo nosso).

104 Ibid. (Grifo nosso).

105 Para o conceito de crítica, ver KOSELLECK, Reinart. Crítica e Crise. Rio de Janeiro: Eduerj/Contraponto, 1999. 
acompanhadas pela Encyclopédie, que já delineara a preocupação com a ordem e a racionalidade do universo urbano. Era a sobreposição da estética das luzes à estética medieval. Posto isso, era necessário refletir sobre novas maneiras de idealizá-la. No Império Português, particularmente, essa nova concepção de cidade ilustrada e suas transformações advindas do processo de reurbanização eram indissociáveis do Estado de polícia, concebido como uma ciência de governo em busca do "bem-estar geral" da nação. ${ }^{106} \mathrm{~A}$ interdependência entre o Estado absolutista e a ação da polícia simbolizava, em última instância, a força (e independência) política do Império Português sob uma perspectiva civilizadora. Como sabemos, O Investigador circulou em grande parte do território brasileiro e, portanto, a divulgação no periódico da leitura de Ideias Gerais sobre a Polícia na Academia Real das Ciências de Lisboa, em setembro de 1813, não foi mero acaso: a Coroa noticiava vieses importantes de seu projeto político através da exaltação do discurso de seus súditos leais que a elevavam à principal agente cultural do Império luso-brasileiro. ${ }^{107}$

\footnotetext{
106 Como homem do governo, o Visconde da Lapa compreendia a ideia de bem-estar geral por uma vertente oficial e, obviamente, socialmente hierarquizada. Dizia o autor: "O fim da polícia é contudo promover, por meios de bons regulamentos, a conservação e aumento da boa prosperidade interior do Estado, e como esta não só compreende todos os bens públicos, e particularmente, porém as disposições e capacidades dos membros da Nação, é evidente portanto, que a polícia pertence vigiar sobre o encadeamento destes objetos, apartando os obstáculos, e promovendo os meios mais conducentes ao bem comum." O fim do manuscrito terminava com a seguinte reflexão: "Não se deve porém admitir que a polícia deve promover, e proteger todos aqueles estabelecimentos, que entretendo as diferentes classes, os impedem, ou da aplicação a objetos mais prejudiciais do Estado, ou as desviam de considerações pouco úteis." BNP. Res., Ideias Gerais sobre a Polícia. Mss. 246, n. 28 (Grifos nossos).

107 IP, Vol. VII, p. 494-495. Sobre o sistema de assinaturas e a circulação de $O$ Investigador Portuguez no Brasil, ver as seguintes edições da Gazeta do Rio de Janeiro - 1811, n. ${ }^{\circ} 63$ e 1813, n. $^{\circ} 81$.
} 
Em Janeiro de 1814, O Investigador publicava uma longa reflexão sobre Gil Vicente, um dos escritores "com que mais se honra a nossa Literatura Nacional". ${ }^{108}$ Os redatores tinham escolhido Gil Vicente (e não outros) por razões muito especiais: porque "desgraçadamente se vê tão pouco conhecido", por ser reconhecidamente o "nosso Plutarco português" 109 entre sábios nacionais e estrangeiros, e, sobretudo, pelo fato de "ter sido um português, e isto é quanto basta para crédito das Musas Lusitanas". ${ }^{110}$ Ao contextualizar a fama e destaque de Gil Vicente, os redatores exaltavam a atitude de Erasmo, um sábio de renome no Velho Mundo que "de propósito aprendera Língua Portuguesa para entender as superiores belezas de Gil Vicente". ${ }^{111}$ Essa afirmação não estava desvinculada de um mote muito caro à filosofia iluminista: a relação entre razão e linguagem, que teve em Rousseau um dos

\footnotetext{
108 Ibid., p. 591.

109 Plutarco foi um estudioso grego (46 d. C.-119 d. C.), nascido na Beócia, autor de uma obra que exerceu grande influência sobre o ensaio e a biografia na literatura ocidental. A sua vasta obra integra dois grupos: Vidas Paralelas, que consiste em 46 biografias de vultos gregos e romanos, e Ética, uma coletânea de pequenos escritos em que são dominantes diatribes e diálogos. Embora tivesse orgulho na sua nacionalidade grega, Plutarco aceitou o domínio romano. $\mathrm{Plu}$ tarco. In: Infopédia [Em linha]. Porto: Porto Editora, 2003-2011. Disponível em: <http://www.infopedia.pt/\$plutarco>. Acesso em: 15 fev. 2011.

${ }^{110}$ Idem, p. 591-592. "Gil Vicente está no "cânone”, desde há muito, e colocado na prateleira dos clássicos, surgindo deste pressuposto consolidado pela passagem do tempo, um sem número de implicações para os seus leitores e investigadores. No panorama ibérico e europeu, a Compilaçam faz, inequivocamente, parte do Cânone, na medida em que a produção dramatúrgica vicentina se fez ecoar pela Europa ocidental de Quinhentos e aparece ainda hoje, passados já os quinhentos anos da apresentação da Visitação, com suficiente fulgor para interessar a críticos, investigadores e gente das artes cénicas. A excepcionalidade da obra de Gil Vicente, o primeiro escritor português a ultrapassar os muros da nacionalidade, chegou até nós com as marcas indeléveis do tempo. FARIA, Paulo Manuel Miranda. Gil Vicente - o Mestre da Corte de D. Manuel e de D. João III. Dissertação de Mestrado. Universidade do Minho. Braga: 2005. p. 8-9

111 Ibid., p. 593 (Grifo nosso)
} 
seus principais expoentes. Em Ensaio sobre a origem das línguas (1781), refletia: “Quando se quer estudar os homens, é preciso olhar perto de si; mas para estudar o homem é preciso estudar mais longe, é preciso primeiramente observar as diferenças para descobrir as particularidades".

Para o filósofo, a "principal causa que as distingue [as línguas] é local, ela vem das regiões em que nascem e da maneira pela qual se formam", o que daria a base para remontar e conceber as suas diferenças e peculiaridades. ${ }^{112}$ Nesse sentido, portanto, Erasmo buscava conhecer não apenas o homem, mas a cultura nacional da qual Gil Vicente não apenas fazia parte, mas era também um grande expoente. A reflexão sobre o escritor português desembocaria em um diálogo crítico do jornal com os leitores, "para a glória e reputação da nossa Pátria". ${ }^{113}$ Ao se colocarem na posição de ousados questionadores com muitas dúvidas, os redatores perguntavam:

Por que razão Gil Vicente, tão famoso em Portugal e na Europa, veio a ser esquecido entre nós a um ponto tal, que nem as suas mesmas obras aparecem; quando dos autores seus contemporâneos, e outros mais que se lhe seguiram, nos tem chegado quase todos os escritos, e deles se tem feito diversas edições?

Por que, sendo nos, ao que parece, os primeiros restauradores do teatro cômico na Europa, e andando quase a par no trágico com a Itália, aonde apareceu a primeira tragédia moderna regular, não havemos tido desde Gil Vicente até o Judeu ${ }^{114}$ autor algum cômico de nome?

112 ROUSSEAU, J. J. Ensaio sobre a origem das línguas. Trad. Fulvia M. L. Moretto. 2. ed. Campinas, SP: Editora da Unicamp, 2003. p. 125 (Grifo nosso).

113 IP, Vol.VIII, p. 593-594.

114 O livro O Judeu é de autoria do luso-brasileiro Antonio José da Silva (1705-1739), considerado o mais representativo autor dramático português da primeira metade do século XVIII português. Aos 34 anos foi preso e executado 
Foram na realidade os Poetas Espanhóis, e mui particularmente, Lopo da Vega e Francisco de Quevedo, imitadores e os díscipulos de Gil Vicente? Ainda mais: Foi ele indisputavelmente o primeiro autor cômico regular da Europa moderna e civilizada? ${ }^{115}$

Com essas interrogações, os editores incentivavam a participação do significativo público leitor, não apenas como forma de endossar a fama literária que pretendiam para o jornal, mas, sobretudo, como meio de valorizar as suas reflexões intelectuais, no sentido de convencê-los a ler a tradição literária da cultura portuguesa como superior, por exemplo, à espanhola, país vizinho com maior ressonância sociopolítica e cultural no Continente. ${ }^{116}$ Novamente, a poesia aparecia como ícone do mais alto grau de civilização. "A poesia, como nos aponta a história, segue a sorte da linguagem. $\mathrm{Na}$ infância das nações, ela é rude, inculta como elas. [...] À medida que as línguas se civilizam perdem esse ressaibo [sic] de barbaridade, a poesia de consoantes", defendiam os redatores. ${ }^{117}$ Neste sentido, a exaltação da cultura portuguesa dá-se tanto para a língua - tida como a filha mais próxima do latim - quanto em relação aos seus poetas modernos, superiores, já que "não escrevem [mais] em consoantes, graças ao progresso da

pela Inquisição em Lisboa, sob a acusação de praticar o judaísmo. DINES, Alberto. Vínculos do fogo I: Antonio Jose da Silva, o Judeu, e outras historias da Inquisição em Portugal e no Brasil. São Paulo: Companhia das Letras, 1992. 115 IP, Vol.VIII, p. 593.

116 Segundo Tengarrinha, O Investigador tinha larga procura em Portugal, sendo lido seguramente por milhares de pessoas. TENGARRINHA, J. "Os comerciantes e a imprensa portuguesa da Primeira Emigração”. Estudos em Homenagem a Luís Antonio de Oliveira Ramos. Faculdade de Letras da Universidade do Porto, 2004. p. 1.077.

117 IP, Vol. VII, p. 393. As consoantes são definidas pelo periódico como "certas toadas uniformes e monótonas", cuja única distinção está no metro. Idem. 
iluminação, e do gosto". ${ }^{118}$ Como bem demonstra a obra seminal de Immanuel Kant, Resposta a pergunta: "Que éo esclarecimento?" (1784), o homem só sairia da menoridade ao atingir a liberdade, concebida como a capacidade de "fazer um uso público de sua razão em todas as questões". ${ }^{119}$

A elevação de Gil Vicente como o (possível) mestre do teatro cômico Europeu, colocava-o como um dos ícones da alta cultura humanista da Europa Ocidental, cuja tradição era indiscutível no avanço das artes e das ciências. "Antes do aparecimento de Gil Vicente, não podemos falar em um teatro em Portugal", pontua o pesquisador Segismundo Spina, que enaltece a obra vicentina pela "presença expressiva do estilo - como quem diz a superioridade estilística do texto literário - a constante renovação dos temas e das formas, a primazia dessa arte em terras portuguesas e a superioridade de suas criações, pelo talento cômico e a estrutura doutrinária dos seus temas". ${ }^{120}$ Gil Vicente em Portugal, e Willian Shakespeare, em Inglaterra, eram os representantes por

\footnotetext{
118 Ibid., p. 393. "Os redatores explicavam a superioridade da poesia nesses termos. Mas nem todas as línguas têm harmonias da Grega e Latina e é singular que as duas modernas, notoriamente as mais cultivadas, são excluídas deste número, a Francesa e a Inglesa; pois uma é pelo gênio abreviador, e a outra alongador das suas sílabas, não podem com facilidade metrificar-se com a elegância hexamétrica, por mais tentativas que se tenham feito sobre isso. O que não acontece com a nossa Portuguesa, que a este respeito nos parece muito superior à Alemã; a única moderna que apresenta a metrificação característica de Homero, e de Virgílio [...]. Em todo o gênio da glória nacional, pode a nação portuguesa distinguir-se. Ela tem mostrado ao mundo que tem criado Heróis, capazes de manejar a massa de Hércules, de imitar a rapidez e valor de Aquiles." (Idem, p. 396) (Grifos nossos).

119 KANT, Immanuel. Resposta a pergunta: “Que é o esclarecimento?”. In: Immanuel Kant. Textos Seletos. 2. ed. Trad. Raimumdo Vier e Floriano de Sousa Fernandes. Petrópoles: Editora Vozes, 1985. p. 104.

120 SPINA, Segismundo. "Introdução". In: Gil Vicente: O Velho da Horta; Auto da Barca do Inferno; A Farsa de Inês Pereira. São Paulo: Editora Brasiliense, 1996. p. 8-9 (Grifos nossos).
} 
excelência nas artes teatrais do humanismo europeu. Com esta mensagem, O Investigador colocava os dois países diante de um equilíbio cultural que, implicitamente, disputava o espaço de hegemonia entre os paradigmas literários das nações consideradas mais civilizadas do Velho Mundo. ${ }^{121}$

Incentivar a participação dos leitores tinha um objetivo claro no jornal: formar, evidenciar e consolidar a força intelectual da comunidade luso-brasileira - que se pretendia em consonância com as decisões políticas da monarquia portuguesa - no universo da imprensa londrina. Em abril de 1812, quase um ano depois do início da publicação, Funchal enviava para o Brasil dois ofícios que justificavam a continuidade d'O Investigador: os governadores do Reino informavam-lhe sobre a circulação do Correio Braziliense em Lisboa, escrito pelo "libelista revolucionário". ${ }^{122}$ Dizia o diplomata:

Os ofícios por si falam, e creio que justificam a necessidade da espécie de protesto que eu faço pelas consequências futuras. Os motivos que me persuadem a assim obrar a respeito da probidade do Correio Braziliense são os mesmos que tenho levado à Real Presença, e que S.A.R., parece aprovar completamente, e em que representei a necessidade absoluta, e urgente de um Jornal como o Investigador para servir de antídoto aos métodos usados para desacreditar o Governo de S.A.R. e fazê-lo odioso ao Ministério Britânico. ${ }^{123}$

A questão é que a comunidade luso-brasileira em Londres também tinha interesses e divergências muito particulares.

121 A importância de Gil Vicente no teatro se estende até os dias atuais, sendo considerado por Segismundo Spina tão importante quanto Homero, Camões e Shakespeare. Idem, p. 7.

122 ANTT/ MNE_ Livro 451, N. 552.

123 Ibid., N. 347. 
"Quatro forças, com frequências divergentes, exerceram influência relevante nesta imprensa em língua portuguesa em Londres: os negociantes portugueses (sobretudo através do seu Clube em Londres), a Corte e o governo do Rio, os governadores de Lisboa e a maçonaria", analisa José Tengarrinha, ao mapear a sobrevivência e as relações políticas dos "jornais na emigração". ${ }^{24}$

Disputar a atenção dessa gama heterogênea de leitores, tornando-se um órgão de destaque na formação da opinião pública, era o que movia O Investigador Portuguez e o Correio Braziliense nesse debate. Hipólito da Costa, por exemplo, tinha muito interesse pelo comércio luso-anglo-brasileiro por uma razão central: seus leitores (e subscritores) eram, na maioria, negociantes portugueses que viviam e atuavam como profissionais liberais na Inglaterra. Entre 1811 e 1819, esses dois periódicos, considerados pelo pesquisador José Carlos Oliveira "paradoxalmente irmãos siameses", viveriam em disputa, discórdia e concorrência, procurando cada um à sua maneira se mostrar mais imparcial e confiavél que o outro.

Em maio de 1812, Hipólito se posicionava negativamente diante do desafio de "guerra" proposto pelo Investigador Portuguez. Dizia:

Não aceitamos o desafio: porque não temos razão de interesse público para fazer guerra às pessoas daqueles Redatores; nem o nosso jornal deve servir de veículo de observações individuais, a menos que não julguemos que elas interessem o público. Não julgamos também que devemos fazer guerra ao Jornal; porque é obra literária que pode produzir bens à Nação; e já produziu um, que é estimular a que se escrevam obras da mesma natureza. ${ }^{125}$

124 TENGARRINHA, José. “Os Comerciantes e a Imprensa... Op. Cit., p. 1.078.

125 CB. Vol. VIII, p. 716. 
Apesar de negar o embate com o Investigador nos moldes de uma "guerra impressa" e reconhecer os méritos literários da publicação, Hipólito não se eximia de suas responsabilidades como homem de imprensa: sempre que as provocações fossem postas à prova, ele estaria pronto para respondê-las. Vejamos:

Mas parece-nos que sem incorrer da nota de cavaleiros errantes da escola do grande guerreiro de La Mancha, podemos reservar-nos o direito de responder, e seguramente o faremos, aos argumentos que os Senhores desafiantes produzirem, quando as nossas ideias os não aprovarem; e parece-nos que o podemos fazer sem mandar um Arauto a aceitar o desafio de guerra. ${ }^{126}$

Em agosto do mesmo ano, os redatores d'O Investigador respondiam a Hipólito da Costa, na tentativa de menosprezar os seus conhecimentos nos diferentes campos do saber.

\begin{abstract}
Sr. Editor,
Depois de V.Mce ter acumulado o quanto pode de invectivas e acusações especiais contra o Investigador, sai-se a página $746[\mathrm{sic}]^{127} \mathrm{com}$ a singular observação, de que nao aceita o nosso desafio. Nós dizemos mais; é que não o desafiamos; nem sabemos como jornalistas qual seria o campo de batalha para que o desafiássemos. Ciências? O seu jornal não trata disso. Literatura Portuguesa? Vmce já declarou magistralmente que a tinha em não mui elevado conceito (expressão feliz sua que compreende em si mesma a doutrina e o exemplo). Literatura Estrangeira? Vmce é tão avaro da que possui, que [a]inda não quis dar desse tesouro a mais pequena amostra a seus leitores. Onde poderíamos pois encontrarmos com Vmce?
\end{abstract}

\footnotetext{
126 Ibid.

127 Aqui fazemos uma errata. A resposta do Correio Braziliense foi publicada originalmente no periódico, Vol. VIII, p. 716.
} 
Sendo também $O$ Investigador uma folha subsidiada pelo governo português, algumas questões se impuseram ao longo dos anos de vigência do periódico (1811-1819), dentre elas a relação dos redatores com o poder público - nas temáticas e enfoques que seriam apresentados no periódico - e a própria sobrevivência econômica da folha. ${ }^{128}$ Diante dessa realidade, os redatores continuavam as alfinetadas no redator do Correio.

Seria por ventura nas suas reflexões, que contém os dois artigos Portugal e Brasil, que se vê serem o único objeto do seu Jornal? Aí estimamos não ter nada de comum com Vmce porque a superficialidade daquelas reflexões se tem algum vulto, é só o que lhe dão as personalidades, as notórias calúnias, e incitamentos revolucionários, de que elas abandão [sic], de maneira que todo o leitor quando acaba de as ler [sic], (e mesmo o malévolo que gosta de maledicência), acha por único resultado um verdadeiro caput mortuum. ${ }^{129}$

Mais do que tentarem circunscrever a idoneidade dos valores jornalísticos pela livre escolha dos diversos tipos de leitores, os redatores do Investigador tentavam minar o tipo de jornalismo praticado por Hipólito - segundo eles calcado em valores muito duvidosos: a calúnia e o incitamento revolucionário. ${ }^{130}$ Para o

128 Para a compreensão da questão, ver BOISVERT, Georges. "La presse périodique portugaise de Londres. Notes sur les circonstances de son apparition et de son développement." Sillages. Sus la direction de R.A. Lawton. N. 4. (1974). Poitiers: Département d'Études Portugaises et Brésiliennes de l'Université de Poitiers, 1974. p. 69-88; BOISVERT, Georges. "Le comte de Palmela et la presse potugaise libre (1816-1820) d'aprés des documents diplomatiques inédites." Arquivo do Centro Cultural Português. Paris: Fundação alouste Gulbenkian/Centro Cultural Português, 1982. p. 459-509.

129 IP, Vol.IV, p. 280.

130 Sobre a discussão acerca dos valores predominantes na imprensa da época ver: MEIRELLES, Juliana. Imprensa e poder..., cap. 2., p. 91-146. 
historiador Georges Boisvert, no entanto, a colaboração intelectual de Vicente Pedro Nolasco da Cunha era mais fictícia que real, uma vez que ele priorizava as vantagens econômicas no exercício do seu ofício. ${ }^{131}$ Em Abril de 1813, Funchal discutia a problemática do subsídio financeiro da Coroa aos jornalistas. Em documento Secretíssimo, o diplomata informava às autoridades do Rio de Janeiro que novamente passava "a consultar com os Redactores do Investigador [sobre] a precisão de lhes continuar por algum tempo mais as conveniências que lhes tem feito". ${ }^{132}$ A carência de recursos para a manutenção da folha era um desafio constante. Portanto, fazia-se necessária a busca de apoio financeiro de novos subscritores para promover a leitura no Brasil, e assim "confirmar nos ânimos Portugueses os sentimentos de lealdade e Patriotismo que Malévolos procuram destruir." ${ }^{133}$ Realmente, a dipusta entre os dois jornais estava presente em muitos campos do conhecimento: da economia à ciência, perpassando a política e a literatura. Em março de 1813, Hipólito da Costa fazia um breve comentário sobre a reflexão de um dos redatores d'O Investigador, intitulado "Regulamentos do Governo sobre o comércio em Portugal. Resposta a certa passagem do Jornal, pseudo Científico". Sem meias palavras, a análise do jornalista desqualificava os atributos de seu interlocutor e rival.

A p. 227 acha uma providência interina a respeito da legalidade dos vasos e mercadorias Britânicas, que exigem de nós algumas observações, as quais as arranjaremos de maneira, que sirva, também de resposta a um artigo, que sobre esta matéria apareceu no Jornal Pseudo Científico,

131 BOISVERT, Georges. "Le comte de Palmela et la presse potugaise libre (18161820)..., Op. Cit., p. 472

132 ANTT/ MNE_ Livro 451, N.445.

133 Ibid. (Grifo nosso). 
que se supõem o foco das ciências e boa lógica a tal ponto, que não resta nada dessas coisas boas a outro algum jornal. Quanto ao escritor de tal parágrafo ${ }^{134}$, que mostra muito bem quem é, pelo muito que se picou com nossas observações passadas, e pela confusa trapalhada de ideias com que fala todas as matérias em que se mete, e com que trata todos os negócios que tem a infelicidade de lhe cair nas mãos, melhor lhe fora não se meter a redator, e escritor de parágrafos, para jornais, para o que tem mui pouco jeito: as intrigas de Corte lhe são um tanto mais familiares: e contentar-se com ela seria mostrar prudência, já que não tem juízo. ${ }^{135}$

Sob os mais diversos temas, as réplicas e tréplicas entre os redatores da imprensa luso-brasileira produzida em Londres se sucederam ao longo de todo o período, compondo uma documentação muito rica sobre as principas preocupações vigentes no universo público no período joanino. O foco dessa disputa no campo retórico era o leitor. Porém, como bem definiu Roger Chartier, "cada leitor, a partir de suas próprias referências, individuais ou sociais, históricas ou existenciais, dá um sentido mais ou menos singular, mais ou menos partilhado, aos textos de que se apropria". ${ }^{136}$ Esse fato tornava ainda mais complexa a atividade dos homens de letras no raiar do século XIX, uma vez que eram conscientes de que dependiam dessa gama heterogênea de

${ }^{134}$ O parágrafo a que Hipólito se refere é “O Princípio de que partimos sempre em nossas observações sobre o comércio de Portugal, é um teorema geralmente admitido por todos os economistas, em todas as nações, que "o comércio deve ser livre, e que o Governo sempre lhe fará mais mal do que bem, todas as vezes que se intrometer nesta matéria em coisa alguma, além da imposição bem pensada, e cobrança bem regulada dos direitos de alfândega" e foi publicado antes da citação supracitada no texto. CB. Vol. X, p. 281.

135 Ibid.

136 CHARTIER, Roger. “Prefácio”. In: CHARTIER, R. Práticas de leitura. Trad. Cristiane Nascimento. São Paulo: Estação Liberdade, 1996. p. 20. 
leitores reais para manterem a liderança no processo de formação da opinião no espaço público. Dessa forma, os redatores buscavam conquistar a todo custo a confiança de seus interlocutores; já que esta garantia-lhes maior prestígio e credibilidade dentro da sociedade de Corte. Aos leitores, por fim, cabia-lhes o papel tanto de espectadores das habilidades do orador ${ }^{137}$, quanto de críticos de suas condutas.

Como espectadores, adentravam no universo da observação estrutural do jornal enquanto um documento com status social preciso: este fora produzido com o intuito de instruí-los acerca dos fatos presentes, e, assim, conduzi-los à reflexão. Como críticos, buscavam o rastro das contradições presentes nos diferentes discursos jornalísticos para, assim, encontrar uma verdade isenta de contradições. Na prática, o crítico tinha em si a figura do acusador e defensor em uma só pessoa. Nas palavras de Reinhart Koselleck, “o crítico eleva-se à instância suprapartidária e torna-se o advogado da razão." ${ }^{138}$ Ao se posicionar acima dos partidos políticos, tem como tarefa "estabelecer" a verdade, para assim construir o melhor dos futuros possíveis.

Um exemplo interessante desse tipo de disputa retórica ocorreu entre os meses de agosto e outubro de 1813. A discussão central girava em torno das divergências acerca da posição política de Lord Strangford diante da aplicação do Tratato de 1810 entre Portugal e Inglaterra. A crítica d'O Investigador acerca da postura do ministro foi interpretada por Hipólito como uma ação de má fé, cuja finalidade era seguir adiante com o plano de intrigar ingleses e portugueses. Afirmava o jornalista:

137 SOUZA, Roberto Acízelo de. O Império da Eloquência. Retórica e Poética no Brasil Oitocentista. Rio de Janeiro: EdUERJ, EdUFF, 1999, p. 8.

138 KOSELLECK, Reinart. Crítica e Crise... Op. Cit., p. 96-97. 
Este plano está tão palpável neste N. ${ }^{\circ}$ do Jornal Científico, desde o princípio até o fim; que não nos admiraremos se virmos todo traduzido em francês, e impresso em Paris, antes do tempo. E lá julgarão, que não é este o primeiro serviço, que antes tanto em prosa como em verso, tem os redatores feito ao Senhor Imperador Napoleão o Magno \&c. \&c. \&c. ${ }^{139}$

Para além de insinuar certa simpatia dos redatores com Napoleão, também colocava Funchal em uma situação deveras delicada: assegurava que o embaixador português "recebe em sua casa, e aparece em público com um homem condenado à morte em Portugal, por crimes de alta traição; ao mesmo tempo em que recusa admitir em sua ala a presença de homens, banidos sim de Portugal; mas sem crime, sem sentença, sem acusação." ${ }^{140}$ Não bastasse a dúvida levantada sobre o caráter de Funchal, Hipólito ainda rotulava os redatores d'O Investigador de "partidistas dos Souza", isto é, da família Souza Coutinho. Como assevera o historiador José Alves, as tensões ideológicas desse período "não podem ser reduzidas apenas a uma oposição entre utopia e política pragmática, entre pensamento filosófico e razão de Estado. Há que ter em conta, para além das ideias e das obras, das instituições e das suas práticas, a explosão da sociabilidade, da conversação, do oral, do escrito." ${ }^{141}$ Todas essas múltiplas dimensões - das correspondências diplomáticas às recepções de leituras desses periódicos -, englobavam o complexo universo da imprensa interatlântica, constituindo, dessa forma, o emergir de um novo espaço público.

139 CB. Vol. XI, p. 229.

140 Ibid. (Grifo original).

141 ALVES, José Augusto dos Santos. A opinião... Op.Cit., p. 17. 
A ampla defesa dos redatores do Investigador saía a público em outubro de 1813.

O arrumador do Armazém dá a entender que a carta que principiamos a inserir em o N. ${ }^{\circ} 26$ do nosso Jornal sobre o Tratado de Comércio entre Portugal e Inglaterra é forjada por nós. Dizemos que dá a entender, porque ele faz uma mexerufada [sic] de coisas, que mostra bem o desarranjo de sua cabeça, ou o acesso de raiva (mas raiva impotente) em que estava, quando escreveu a dita diatribe. ${ }^{142}$

Ao adentrarem na seara política, os redatores assumiam a "falta de luzes o bastante" para discutirem os pormenores do Tratado de 1810; o que não invalidava as análises da sua publicação, guiadas sempre pelo valor da imparcialidade. ${ }^{143}$ De fato, esse acordo comercial selava a preeminência britânica sobre Portugal e o Brasil. Em meio a uma guerra europeia que limitava drasticamente a perspectiva de lucros da indústria britânica, a expansão do comércio inglês para a América do Sul ganhava cada vez mais peso. Segundo Hobsbawm, a região "veio realmente a depender de importações britânicas durante as guerras napoleônicas, e depois que se separou de Portugal e Espanha, tornou-se quase que totalmente dependente economicamente da Grã-Bretanha." ${ }^{144}$ Já quanto à acusação de partidários da família Sousa Coutinho, reiteravam o seu respeito e aliança sem, no entanto, demonstrarem a subserviência apontada por "Mr. Da Costa."

Respeitamos, e respeitamos muito a família dos Souzas; bastaria para isso o dizer mal dela o arrumador do Armazém; porque ele tem empreendido a honrosa tarefa de

142 IP, Vol.VII, p. 726.

143 Ibid.

144 HOBSBAWM, E. A era das revoluções... Op. Cit., p. 51. 
ocultar o crime, e deprimir a virtude; de canonizar monstros, e de caluniar inocentes. Respeitamos a família dos Souzas; e a parte da Nação que é justa a respeita conosco, porque sabe que esta família e a nenhuma cede em honra, em patriotismo, em limpeza de mãos, e em amor a S.A.R. De resto são homens, e como tais podem errar. Somo-lhes muito obrigados; e a nossa gratidão acabará quando acabarmos de existir. ${ }^{145}$

Particularmente, tentavam justamente mostrar a deslealdade de Hipólito para com a mesma família, desde que este rompera com D. Rodrigo de Souza Coutinho. "Nunca voltamos a casaca aos nossos Benfeitores, ou amigos, quer na bonança, quer na desgraça: desafiamos o arrumador do Armazém, e todos os nossos inimigos para que apontem um só fato, que nos desminta a este respeito"146, concluíam.

O fato é que a exaltação das iniciativas socioeconômicas e culturais, tanto dos ministros portugueses pertencentes à família Souza Coutinho quanto da própria monarquia portuguesa no Brasil era recorrente no Investigador Portuguez. Em Março de 1812, por exemplo, os redatores comentavam sobre as notícias publicadas na Gazeta do Rio de Janeiro, que se referiam às atitudes do governador do Mato Grosso e seu esforço para avivar as comunicações do interior do "vasto Império do Brasil."

Na excelente Gazeta do Rio de Janeiro de 16 de Outubro próximo achamos um artigo que mostra com a maior evidência os paternais Desvelos de Sua Alteza Real o Príncipe Regente Nosso Senhor, e as suas grandes vistas que só tem por mira a Pública Felicidade, o bem de seus Vassalos em cujos corações impera. É para nós um bem doce dever

${ }^{145}$ IP, Vol. VII, p. 727

146 Ibid. (Grifo original.) 
o termos de transcrever para o nosso Jornal um artigo tão interessante; e os nossos leitores imparciais sentirão, quando o lerem o mesmo prazer sincero, e puro, que nós temos em copiar, e que todo o Português, que ama cordialmente a Glória do seu soberano, e o Bem da sua $\mathrm{Na}$ ção, deve necessariamente experimentar. ${ }^{147}$

Nesse discurso, os editores deixavam explícita a relação existente entre as duas publicações: mesmo sendo de naturezas distintas - O Investigador Portuguez, um jornal de caráter enciclopédico, e a Gazeta do Rio de Janeiro, uma folha cuja missão era cumprir o papel de um relato "fiel" da história política do tempo presente (sendo a cronologia, a narração e a coleção de documentos públicos os pontos centrais para que esse papel fosse assimilado de maneira verossímil) ${ }^{148}$-, ambas eram veículos de comunicação subsidiados pela realeza, cuja produção editorial tinha o dever de veicular a força (e o suposto sucesso) dos projetos políticos governamentais. Não era à toa que a Gazeta e O Investigador elogiavam-se mutuamente, circulando nos dois lados do oceano. Essa comunhão de ideias (ou linhas editoriais) também fazia parte de uma política cultural eficaz, da qual um dos pilares era a imprensa interatlântica.

Com a conquista de novos subscritores e, consequentemente, leitores mais bem (in)formados, vemos mais claramente a defesa d'O Investigador pelo direito à educação. No que concerne ao papel pedagógico da imprensa do período,

[...] a informação associada à formação faz da opinião pública ponto nuclear da sociedade, já que, como centro denso, influente nas decisões políticas, no comportamento

${ }^{147}$ Ibid., Vol. III, p. 88.

148 MEIRELLES, Juliana. Imprensa e poder ... Op. Cit., p. 135. 
dos homens de Estado e da própria sociedade, emerge como fator de pressão política, económica e social. ${ }^{149}$

O conceito educacional d'O Investigador, particularmente, "envolvia uma forte componente moral completando a autonomia afirmada, e fazia coincidir no plano da ética o homem social com o homem moral". ${ }^{150}$ É nesse sentido que evidenciar temas considerados de grande relevância para os leitores, como a literatura, era uma maneira de O'Investigador persuadir a Coroa de sua importância, explicitando sua autoimagem através das seguintes palavras: "que o nosso Jornal cada vez mais se faça digno de heróica nação, de quem temos tanta vaidade de ser filhos, e leais admiradores"151. Além de cumpridores competentes e responsáveis de sua missão, na visão de Adelaide Machado, os redatores do jornal se julgavam capazes de regenerar o homem através de uma concepção inovadora de cultura e de íntima relação com o desenvolvimento civilizacional. ${ }^{152}$ Em janeiro de 1814, os redatores veiculavam a reflexão "Memória em que se mostram as vantagens do Estado da Geografia Náutica nas Reais Aulas da Marinha, e o Plano do seu ensino", de D. António da Vesitação Freire de Carvalho. Neste artigo, esclareciam seus leitores sobre a indispensável necessidade do estudo da geografia em geral entre os homens civilizados. Por esse prisma, delineavam o conceito de civilização que defendiam. Vejamos:

\footnotetext{
149 ALVES, José Augusto dos Santos. O poder da Comunicação. A história dos Media dos primórdios da imprensa aos dias da Internet. Lisboa: Casa das Letras, 2005. p. 106.

${ }^{150}$ MACHADO, Adelaide Maria Muralha Vieira. "O Investigador Português em Inglaterra, Jornal Literário, Político. \& C., nos primeiros anos de publicação (1811-1813)". Lisboa: UNL/CLC, 1998. p. 484.

151 IP, Vol. VIII, p. 594.

${ }^{152}$ MACHADO, Adelaide Maria Muralha Vieira. O Investigador Português em Inglaterra, Jornal Literário, Político. \& C., nos primeiros anos de publicação (1811-1813). Dissertação de Mestrado. UNL, 1996. p. 21.
} 
[...] Sendo a civilização da espécie humana uma consequência imediata das repetidas combinações de todos os objectos físicos e morais, que apresenta a ordem do universo; e deduzindo-se as leis gerais, que dirigem a economia da espécie, da multiplicidade de observações de fatos individuais, quando se apreciam para as relações de tempo e lugares, circunstâncias que tanto servem para promover a faculdade de combinar, e deduzir resultados úteis aos interesses do Estado, do que apresentar à mocidade, pouco experiente, o quadro de todos os lugares em que podem passar-se todas as transacções da vida, combinando a ordem presente do globo com todas as situações certas ou prováveis do passado. ${ }^{153}$

A preocupação educacional era de tal monta que, em novembro de 1811, o jornal imprimia dois artigos muito relevantes na seção literatura, intitulados: "Será a educação necessária ou avantajosa [sic] às classes inferiores?" e "Misérias da ignorância e vantagens da ciência". ${ }^{154}$ Neste espaço, os redatores refletiam sobre a necessidade de se educar os súditos, com base nos dois pilares considerados fundamentais à instrução de qualidade: a ciência e a arte, sendo a primeira responsável por estender "as suas benéficas consequências ao gênero humano" e a segunda, por "adornar a humanidade". ${ }^{155}$

No primeiro artigo, a discussão girava em torno da tensão entre as classes sociais e o desenvovimento das virtudes das classes inferiores, sobretudo aquelas relativas à cultura do espírito. $\mathrm{O}$ autor não só ressaltava a falta de espaços educacionais destinados à formação dessas pessoas (escolas, academias e colégios), como também admitia a responsabilidade das classes superiores

\footnotetext{
153 IP, Vol. VIII, p. 408.

${ }^{154}$ Ibid., Vol. II, p. 21-30.

155 Ibid., p. 21.
} 
nesse processo; uma vez que, além destas terem acesso ao conhecimento em espaços específicos de valorização da cultura, ainda vedavam aos pobres a chance de "adquirir" a ciência da civilidade. $\mathrm{O}$ questionamento acerca da postura retrógrada de muitos leitores do periódico era explícito:

Mas talvez alguns de nossos leitores nos perguntem para que é dar educação aos pobres? Serão eles mais úteis nos campos, ou mais hábeis nas lojas dos nossos manufactores? Manejarão eles o malho, e os foles [sic] com mais eficácia por saber ler, ou contar do que se não soubessem o seu alfabeto, ou a sua tabuada? De certo que sim [sic]; estendendo a educação das classes inferiores nos aumentamos as suas faculdades; nós os fazemos vassalos mais respeitáveis, e mais úteis servos. ${ }^{156}$

Como filósofos responsáveis por apontar o caminho para o progresso da nação, os autores defendiam a união das classes superiores em prol das menos abastadas, para que estas pudessem adentrar no mundo das luzes. "Se pois as necessidades da sua situação os privam realmente de tudo aquilo, que se chama educação, diminuamos aquelas necessidades [...] deixemo-los participar de uma porção daquela luz, que deve esclarecer todo o homem que veio ao mundo"157, elucidavam. Já a explicação acerca da necessidade do Império Português constituir, valorizar e usufruir de todos os benefícios advindos da cultura da razão foi o tema do artigo "Misérias da ignorância e vantagens da ciência". Mais do que exemplificarem os diversos comportamentos do

\footnotetext{
156 Ibid., p. 22-23 (Grifos nossos).

157 Ibid., p. 23. Para conhecer o espaço de sociabilidade das classes menos abastadas e suas práticas culturais no período em Lisboa, ver: LOUSADA, Maria Alexandre. Espaços de Sociabilidade em Lisboa: finais do século XVIII a 1834. Lisboa: Tese de doutoramento. 1995.
} 
homem ignorante, os autores exaltavam vivamente as peculiaridades da sociedade portuguesa, nesse processo.

Leitor [...] Levanta o teu espírito com gratidão para o querido objeto do culto cristão. Vê o estabelecido num trono firmado sobre a indagação, sobre a cultura da razão humana, sobre o saber, e benevolência.[...] Louva o Autor de todos os bens, por teres nascido numa idade, e num país onde a benevoência prospera, onde a razão se cultiva, e se anima a indagação; numa palavra, onde a ciência se espande, e é apreciada pelos seus benefícios, e a moralidade, aquele código de deveres, que nós nos devemos reciprocamente, reduzida a uma ciência, está fixando as suas leis sobre a natureza do homem, e não sobre objetos mudáveis de uma nefaria [sic], e sanguinolenta, ou cerimonial, e impostora superstição. ${ }^{158}$

A cultura da razão em Portugal era indissociável da fé católica, principal marco do reformismo ilustrado português. A crítica à laica Ilustração Francesa aparece com maior nitidez em março de 1812. Sobre a vida pública e privada naquele país, antes e depois da Revolução, refletiam:

O sistema do governo, e dos costumes em França deve refundir-se primeiro que possam florescer as virtudes sociais e domésticas, ou mesmo o decoro público reassumir a sua influência. Exemplo diverso deve ser dado pelos regentes da França, se pretenderem seriamente dar eficácia a medidas legislativas, para a reforma da moral pública. Aristóteles disse já, nos seus princípios políticos, que o povo em geral se torna como os chefes que o governam. Se jamais houve país a que esta máxima pudesse aplicar-se é a França. (...) A história nos ensina, que em ponto de costume, os estados têm sido sempre tais quais seus

158 Ibid., p. 28. 
chefes; e de que toda alteração efetuada nos costumes dos grandes tem passado para os pequenos. ${ }^{159}$

De fato, a Revolução Francesa subvertia os valores do Antigo Regime. Na análise de Hobsbawm, a Declaração dos Direitos do Homem e do Cidadão (1789) foi um manifesto contra a sociedade hierárquica de privilégios nobres; o que, contudo, não significava ser a favor de uma sociedade igualitária e democrática. A atuação efetiva do Terceiro Estado, no entanto, colocava em cena um elemento de suma relevância: a vontade geral do povo passava a ser identificada à nação francesa. Essa novidade, na prática, já era a grande revolucão dos conceitos; e era justamente as consequências advindas desse processo que geravam muito medo aos detentores do poder absoluto na Europa. ${ }^{160}$

É sob esse prisma que o discurso dos redatores do jornal ganha maior sentido. Ao criticarem a cultura francesa, os autores tentavam convencer seus interlocutores das qualidades intrínsecas à ciência, sobretudo se esta fosse sempre iluminada pela ética cristã. A providência divina estava acima da humanidade, sendo responsável por "criar homens em muitas nações civilizadas, cujo amor pela moral, e pelas ciências, lançou os fundamentos de todas as vantagens, que atualmente gozamos". ${ }^{161}$ Como podemos notar, tal discurso chocava-se frontalmente com as novas possibiliades de ascensão social abertas pela Revolução Francesa: com a queda da Bastilha (1789), os franceses mostravam ao mundo que

159 Ibid., Vol.III, p. 22-23.

${ }^{160}$ HOBSBAWM, E. A era das revoluções... Op. Cit., p. 77-8. Ainda segundo o autor, "Sem dúvida, a nação francesa, como suas subsequentes imitadoras, não concebeu inicialmente que seus interesses pudessem se chocar com os de outros povos, mas pelo contrário, via a si mesma como inauguradora ou participante de um movimento de libertação geral dos povos contra a tirania."

161 IP, Vol. II, p. 30. 
as leis do homem ganhavam, definitivamente, a primazia sobre as leis divinas. Quanto às profissões, estas agora podiam ser guiadas pelo mérito e talento. Outra grande conquista revolucionária, que apontava nesta direção, foi a promulgação da Constituição de 1793, durante o governo jacobino (1792-1795). Neste documento,

[...] dava-se ao povo o direito ao sufrágio universal, o direito à insurreição, trabalho ou subsistência, e - o mais significativo - a declaração oficial de que a felicidade de todos era objetivo do governo e de que os direitos do povo deveriam ser não somente acessíveis, mas também operantes. ${ }^{162}$

O conceito de povo da Encyclopédie, tendo como referência particularmente a França da segunda metade do século XVIII, considerava-o a parte mais útil, a mais preciosa e, por consequência, a mais respeitável de toda a nação. Segundo o verbete, sendo o povo o estado geral da nação, este se opunha justamente à nobreza. Dessa forma, era composto por trabalhadores, operários, artesãos, comerciantes e financistas, além dos literatos e homens de leis. ${ }^{163}$ Entretanto, a despeito da importância da Encyclopédie para a época, é fundamental que consideremos as especificidades

\footnotetext{
162 HOBSBAWM, E. A era das revoluções... Op. Cit., p. 87.

163 PEUPLE, le, s. m. (Gouvern. politiq.). Autrefois en France, le peuple étoit regardé comme la partie la plus utile, la plus précieuse, \& par conséquent la plus respectable de la nation. Alors on croyoit que le peuple pouvoit occuper une place dans les états - généraux; \& les parlemens du royaume ne faisoient qu'une raison de celle du peuple \& de la leur. Les idées ont changé, \& même la classe des hommes faits pour composer le peuple, se retrécit tous les jours davantage. Autrefois le peuple étoit l'état général de la nation, simplement opposé à celui des grands \& des nobles. Il renfermoit les Laboureurs, les ouvriers, les artisans, les Négocians, les Financiers, les gens de Lettres, \& les gens de Lois [Jaucourt] [Page Link page 12:475] [Gouvernement politique]. Disponível em: <http://encyclopedie.uchicago.edu/>. Acesso em: 28 nov. 2010.
} 
do contexto filosófico português. Como aponta a pesquisadora Carlota Boto, uma "das marcas do Iluminismo português foi a sua dimensão religiosa, convivendo com a ideia de um Estado condutor dos assuntos temporais". ${ }^{164}$ Por essa vertente, o exemplo magno de conduta moral a ser seguida estava circunscrito à figura do chefe supremo da nação, neste caso D. João, responsável por incutir vícios e virtudes no universo público. Em um "mundo de ponta cabeça”, na expressão do historiador Cristopher Hill, era necessário a máxima vigilância sobre os súditos do Imperio Português. As insurreições vinham dos dois lados do Atlântico. Da América, a independência dos EUA (1776) e do Haiti (1791), no final do século XVIII, e o início do processo de independência da América Espanhola, no alvorecer do século XIX. Da Europa, para além da França, a autonomia da Irlanda (1782), Bélgica (1787), Holanda (1783) e Genebra (1782) ${ }^{165}$ também emergiam como exemplos de insubordinação política. ${ }^{166}$

Se por um lado a monarquia portuguesa tentava evitar a todo custo o contágio das ideias sediciosas vigentes em todos os movimentos políticos de contestação à antiga ordem; por outro, o discurso da Coroa exaltava as nações europeias que deveriam ser tidas como exemplos a serem seguidos. Neste particular, o destaque dava-se para a Inglaterra, considerada no período um exemplo singular de civilização política e dos costumes. Durante todo o governo de D. João, o diálogo com os valores da cultura britânica foi uma constante: entre os temas mais caros à política

164 BOTO, Carlota. A dimensão iluminista da reforma pombalina de estudos: das primeiras letras à universidade. Revista Brasileira de Educação vol.15 n.44. Rio de Janeiro maio/ago. 2010. p. 282.

165 Para uma análise da leitura de Rousseau sobre a tradição política de Genebra, ver VENTURI, Franco. Utopia e Reforma no Iluminismo. Trad. Modesto Florenzano. Bauru: Edusc, 2003 (Cap. 3. “De Montesquieu à Revolução”, p. 139-179).

166 HOBSBAWM, E. A era das revoluções... Op. Cit., p. 72. 
cultural joanina estavam o desenvolvimento no campo das artes e das ciências.

Tal era a integração cultural ${ }^{167}$ entre os dois países que, em janeiro de 1813, o Conde de Funchal escrevia aos ministros de D. João sobre a petição referente à ajuda financeira a José Martins Carvalho, um "artista que veio com grandes recomendações dos Senhores Governadores do Reino para aperfeiçoar-se na Pintura e Desenho; para que mostra um decisivo talento". ${ }^{168}$ A guerra peninsular impedia-o de se aperfeiçoar nos países onde o desenho e a pintura eram os grandes berços da arte europeia, como Itália e França, sendo-lhe, portanto, recomendada a escola de Londres; também um bom centro cultural. Nesta comunicação, Funchal solicitava o auxilio financeiro do Príncipe Regente para o aprimoramento artístico de seu súdito. ${ }^{169}$ Ao contrário do que nos aponta o discurso do ministro português, o sistema educacional na Inglaterra era precário. "Oxford e Cambridge, as duas únicas universidades inglesas, eram intelectualmente nulas, como o eram também as sonolentas escolas públicas", afirma o historiador Eric Hobsbawm. A ressalva do autor, porém, dá-se para a importância das Academias inglesas. Estas, contudo, por mais que

\footnotetext{
167 Utilizamos aqui o conceito de Integração Cultural, assim definido no Dicionário Crítico de Política Cultura: "Intercâmbio de produtos e serviços culturais entre localidades de uma mesma região, regiões de um mesmo país ou de países e territórios distintos, de tal modo que populações ou comunidades diferentes passem a fazer parte de um mesmo sistema de produção cultural, isto é, de modo que seus produtos culturais penetrem num certo circuito e sejam passíveis de uso e consumo por todos que fazem parte desse sistema. [...] Em todo o processo de integração está em jogo a questão das hegemonias e das diferenças [...]." COELHO, Teixeira. Dicionário Crítico de Política Cultural: Cultura e Imaginário. 3. ed. São Paulo: Editora Iluminuras/Fapesp, 2004. p. 221-222 (Grifos do original).

168 ANTT/ MNE _ Livro 451, N.389, p. 124.

169 Ibid.
} 
fossem bem conceituadas na Europa, tinham sido fundadas por dissidentes inlgeses, sendo, portanto, excluídas do sistema educacional anglicano. ${ }^{170}$

Para os redatores d'O Investigador, enxergar o universo britânico como uma importante referência cultural igualmente se estendia para os progressos que a monarquia pretendia para a América, considerada "um Continente imenso, e rico em que se está formando um vasto Império". ${ }^{171}$ Como locus de onde se emanava toda a ordem monárquia, o Novo Mundo carecia "de todos os auxílios que as Artes, e as Ciências pod[iam] prestar-lhe"172, necessitando ser detalhadamente pensado para se "elevar ao grau de esplendor e grandeza de que é suscetível". ${ }^{173}$ Segundo Maria de Lourdes Viana Lyra, esta ideia estava em consonância com os pressupostos do reformismo ilustrado, cujo projeto era a edificação de um império atlântico, onde haveria a união entre o Velho e o Novo Mundo português. ${ }^{174}$ Ainda de acordo com Lyra, uma vez que o Rio de Janeiro se tornara "o ponto referencial da unidade nacional portuguesa e o garantidor da prosperidade geral" ${ }^{175}$, o embasamento político-ideológico voltava-se para a concretização de um projeto posterior da fundação do Império brasílico.

É particularmente sob esse viés que se se estruturava o discurso político d'O Investigador. Ao assumir a missão de ter como mote o progresso dos conhecimentos científicos vigentes

\footnotetext{
${ }^{170}$ HOBSBAWM. Eric. A era das revoluções... Op. Cit., p. 46.

171 IP, N.I, Prospecto, p. 2.

172 Ibid. (Grifos nossos).

173 Ibid.

${ }^{174}$ LYRA, Maria de Lourdes Viana. A utopia... Op. Cit., p. 18. (Grifos do Original).

175 Ibid., p. 19. Uma análise instigante sobre o papel d'O Investigador Portuguez na Inglaterra é a da historiadora Angela Domingues em DOMINGUES, Angela. "Notícia do Brasil Colonial: a imprensa científica e política a serviço das elites (Portugal, Brasil e Inglaterra).” Revista Varia História. Belo Horizonte. Vol. 22. N.35, 2006, p. 150-174.
} 
na época, o jornal se comprometia a exibi-los e analisá-los tendo como foco principal a aplicação para a utilidade geral. ${ }^{176} \mathrm{Com}$ essa prédica, sua linha editorial buscava demarcar as diferenças existentes com o Correio Braziliense no que se referia à ciência. ${ }^{177}$ Entre setembro de 1812 e abril de 1813, a seção "Literatura" apresentava a tradução de Travels in the Interior of Brazil, do mineralogista inglês John Mawe. O livro era digno de ser veiculado no periódico, sobretudo por duas razões: por ser dedicado ao Príncipe Regente e ser a primeira relação impressa sobre as viagens no interior do país, com a prévia e plena aprovação do Soberano. Dois outros detalhes não menos relevantes destacavam a obra de Mawe como literatura científica: esta tinha caráter pragmático e era voltada exclusivamente para o melhoramento do Brasil. O cientista inglês admirava D. João justamente por ser "um homem dado às indagações minerológicas, e que desejava explorar o vasto campo que oferecem os seus vastos e ricos domínios"; o que o levou a patrocinar o seu projeto. ${ }^{178}$ Além disso, também o livro teve grande ressonância na Europa. ${ }^{179}$

\footnotetext{
176 IP, N.I, Prospecto, p. 2. Segundo Adelaide Machado, "Podemos acompanhar no Investigador o debate em torno das principais questões científicas coevas, principalmente no campo da medicina, já que esta ciência adquirira estatuto privilegiado em nome duma filosofia que preconizava relações de interdependência entre saúde física e moral. Sendo assim, as descobertas naquele campo, coadjuvadas com as inovações da química assumiam a máxima importância e provocavam extensa polémica. Neste âmbito vários temas foram debatidos, envolvendo os redactores nuns casos, e pondo o jornal à disposição de investigadores portugueses noutros. Ao mesmo tempo traduziam-se e divulgavam-se debates em curso em Inglaterra”. MACHADO, Adelaide. O Investigador Portuguez..., p. 25.

177 Para uma análise comparativa entre os dois jornais no que concerne à divulgação científica (sobretudo estruturalmente - os diferentes temas e seções), ver OLIVERIA, José Carlos. Os periódicos portugueses de Inglaterra e a Cultura Científica Brasileira (1808-1821). Revista da SBHC, n.19, 1998, p. 31-62; TENGARRINHA, José. Os Comerciantes e a Imprensa ... Op. Cit.

178 IP, Vol. IV, p. 369-370.

179 John Mawe (1764-1829), mineralogista inglês, viveu no Brasil entre 1807 e 1811. Acolhido pelo governo joanino, desenvolveu seu trabalho de pesquisa
} 
Travels in the Interior of Brazil teve duas edições em Londres em um período de nove anos (1812-1821). ${ }^{180}$ Durante a mesma época, a obra foi traduzida também para o francês, italiano, holandês, sueco, alemão, russo e, obviamente, para o português; com uma edição da Impressão Régia de Lisboa, em 1819, sob o título Viagens ao interior do Brasil, com huma exata descripção das Ilhas dos Açores, por João Mawe, Inglez. Authorizadas pelo Rei Fidelíssimo D. João VI, Nosso Senhor, a benefício da Livraria do Convento de S. Francisco da Cidade. ${ }^{181}$

O diálogo entre o mineralogista britânico e o governo de D. João foi tão amplo que, em julho de 1812, o Conde de Funchal remetia para o Brasil uma carta de Mawe para o Príncipe. Além da correspondência, o diplomata esclarecia o que compunha o restante da correspondência:

científica sob o convite de D. Rodrigo de Sousa Coutinho, principal ministro de D. João na época. Com mais de uma dezena de trabalhos impressos sobre mineralogia e geologia, e uma memória inédita intitulada On a Gold Mine in South America. Em 1811, já em Londres, Mawe abriu uma loja às margens do Rio Tâmisa, onde adquiriu grande renome como perito conhecedor de minerais e pedras preciosas em particular. LESSA, Clado Ribeiro de. "Introdução" In: MAWE, John. Viagens ao interior do Brasil. Trad. Selena Benevides Viana. Belo Horizonte: Editora Itatiaia; São Paulo: Edusp, 1978. p. 16.

${ }^{180}$ Publicado pela mesma editora, a Longman, Hurst, Ress, Orme \& Brown. Paternoster-Row, os títulos das duas edições são ligeiramente diferentes. Vejamos: Mawe, John. Travels in the Interior of Brazil, particularly in the Gold and Diamond Districts, by authority of the Prince Regent of Portugal. Including a Voyage to the Rio the la Plata and a Historical Sketch of the Revolution of Buenos Aires. Longman, Hurst, Ress, Orme \&Brown. Paternoster-Row. 1812. Já a edição de 1821 é intitulada Travels in the Interior of Brazil; with notices on this climate, agriculture, commerce, population, mines, manners, and customs: and a particular account of the Gold and Diamond districts. Including a Voyage to the Rio the la Plata by John Mawe, second edition.Longman, Hurst, Ress, Orme \&Brown. Paternoster-Row; and sold by the author, 149, Strand, 1821 (Grifos nossos).

${ }^{181}$ O título ainda era composto por: "a obra foi promovida pelo R.P. M. Fr. Polidoro de N.S. da Lapa, leitor de Theologia e Bibliothecario da mesma." Apud LESSA, Clado Ribeiro de. "Introdução". Op. Cit., p. 16. 
Tenho a honra de remeter igualmente um exemplar que mandei encadernar, e que J. Mawe oferece a S.A.R. assim como três exemplares para os Ex.mos Secretários de Estado. Junto vai um maço com outro exemplar, e Carta do Autor para Lord Strangford. ${ }^{182}$

A leitura de Travels era de tal forma considerada importante para o avanço científico do Brasil que o livro era antes remetido aos homens de confiança do Príncipe, para que estes não apenas conhecessem os resultados da pesquisa do mineralogista acerca do território brasileiro, mas também formulassem novas maneiras de cuidar desse imenso espaço, a partir do que propunha Mawe. Como já apontara D. Rodrigo de Souza Coutinho no final do século XVIII, o Brasil era uma parte fundamental do Império, e era necessário discutir amplamente as potencialidades do que o País poderia vir a ser. ${ }^{183}$

A estrita relação do mineralogista inglês com a orientação científica dos ministros reais é tão evidente que, em março de 1813, o viajante traduzia para o português algumas das suas sugestões acerca da limpeza e navegação dos rios, com base na experiência realizada no Rio Tâmisa. Na correspondência enviada à Corte, Funchal detalhava a conversa que tivera com Mawe:

\footnotetext{
182 ANTT/ MNE_Livro 451, N.374, p. 39.

183 COUTINHO, D. Rodrigo de Sousa. "Sobre os melhoramentos dos domínios de S. Majestade na América”, 1810, p. 25 in LIMA, Américo Pires de. Memória de D. Rodrigo de Sousa Coutinho ( $1^{\circ}$ Conde de Linhares) "Sobre os melhoramentos dos domínios de S. Majestade na América”. Coimbra: Coimbra Editora Limitada, 1948. Em relação à posição geopolítica e às medidas a serem tomadas, o ministro refletia: "A feliz posição do Brasil dá aos seus possuidores uma tal superioridade de forças pelo aumento da povoação, que se alimenta de seus produtos, e facilidade do comércio, que sem grandes erros políticos jamais os vizinhos do norte e do sul lhes poderão ser fatais [...] Para assegurar os meios da nossa superior força, é que com os olhos políticos se deve estabelecer a divisão das nossas capitanias, e aí salta aos olhos a necessidade de formar dois grandes centros de força, um ao norte, outro ao sul [...]." Ibid, p. 25-26.
} 
[Ele] assegurando [me] que um modelo dos Barcos chatos que se usam no Rio Tâmisa para limpar o seu Alveo [sic], se fosse mandado por ordem de S.A.R.P.R.N.S para a Capitania das Minas Gerais, o aumento dos quintos compensaria toda a despesa, e participações que se concedessem à ferragem que fosse do Rio de Janeiro; mandei-lhe fazer o Modelo, que, em seu nome, tenho a honra de oferecer a S.A.R. ${ }^{184}$

Mais adiante, o diplomata ressaltava a explicação do mineralogista sobre o emprego deste barco no Tâmisa, podendo o mesmo método ser empregado no Brasil "para levantar o cascalhão do Alveo dos Rios um pouco profundos, e cujo curso não se pode mudar com facilidade”. Mawe não só entregava nas mãos de Funchal o modelo encomendado, como também se responsabilizava pelas despesas do pedido. ${ }^{185}$ No fim do ano seguinte, em dezembro de 1813, Funchal recomendava a Mawe a "Colecção de Minerais pedida para S.A.R., o Sr. Príncipe da Beira”, prometida para o paquete daquele dia, 1 de Abril de 1814. Tendo ido à sua presença, o mineralogista assegurava mandá-la "bem encaixotada e cada fóssil embrulhado por si até as horas de ir com esta mala”. Por fim, esperava que o inglês não faltasse até a saída do paquete. ${ }^{186}$ Dentre as correspondências de Funchal nesse período, encontramos uma carta de caráter Secretíssimo, que pedia ao Príncipe Regente uma mercê muito especial: a concessão exclusiva de 14 anos ao negociante português, José Sebastião de França, para que este introduzisse "máquinas úteis ao Brasil" na capitania de Pernambuco. Vejamos o documento na íntegra:

\footnotetext{
184 ANTT/ MNE _ Livro 451, N.426.

185 Ibid.

186 Ibid., N. 563.
} 
Ilmo. Exmo. Sr.

Londres, 9 de Abril de 1813.

Tenho a honra de pedir a V. Ex. a, que se digne por na presença de S.A.R. o Príncipe Regente N.S. a petição que faz um muito digno negociante Português José Sebastião de França. Eu inquiri no Inventor Mr. Braanh a verdade [:] se ele se obrigava a vender ao suplicante todas as Imprensas que fossem pedidas para a Capitania de Pernambuco enquanto durasse o Privilégio. - obrigação muito real porque ele tem a Patente Ordinária (ou Privilégio Exclusivo) para 14 anos.

Com esta certeza que desfaz o embaraço que poderia haver se alguém no intervalo da Mercê exportasse a mesma Máquina para Pernambuco. $2 .^{\circ}$. Com a declaração que a Mercê não abrangeria as outras Capitanias - prometi de representar a S.A.R. que seria muito justo este privilégio exclusivo - limitado como prémio da primeira feliz lembrança e estímulo para todos os mais Vassalos que introduzirem máquinas úteis no Brasil. ${ }^{187}$

Como sabemos, não houve qualquer mudança na política impressa do governo joanino até a lei de 28 de Agosto de 1821, que suspendia a censura prévia no Brasil, permitindo aos autores e editores a liberdade de imprensa. A negação deste tão "nobre pedido" indica-nos o alto grau de importância da arte de imprimir e a preocupação da Coroa em manter sob suas rédeas o controle da produção e circulação de ideias políticas. Neste período, o negociante português Manuel Antonio da Silva Serva foi o único que obteve a licença real para imprimir a gazeta Idade d'Ouro do Brasil, produzida na capitania da Bahia, a partir de 1811. Durante boa parte de sua vigência (1811-1823), o periódico baiano esteve sob a estrita vigilância do Conde dos Arcos, governador da capitania. ${ }^{188}$

\footnotetext{
187 Ibid., N. 443 (Grifos nossos).

${ }^{188}$ NIZZA DA SILVA, Maria Beatriz. A Primeira Gazeta da Bahia: Idade d' Ouro do Brasil. São Paulo: Editora Cultrix, 1978.
} 
A discussão pública ou privada dos diversos temas que, de alguma forma, relacionavam-se à formação da opinião pública mostram como a rede de relações entre a Corte do Rio de Janeiro, Londres e Lisboa estava alicerçada em uma problemática política interatlâtica stricto sensu: a sustentação do Império Português nos dois lados do Atlântico era intrínseca à diplomacia lusitana no Velho Mundo. Nesse sentido, destaca-se o cargo de plenipotenciário em Londres. Ao ocupar o posto por 11 anos (1803-1814), o Conde de Funchal teceu relações de grande importância no diálogo entre as capitais do Império Português e Britânico. Irmão de D. Rodrigo de Souza Coutinho, D. Domingos vinculava-se ideologicamente ao "partido inglês", que defendia tenazmente uma aliança estreita entre Portugal e Inglaterra. Além disso, Strangford (plenipotenciário inglês no Brasil) era seu maior interlocutor.

Não por acaso, em finais de 1813, Funchal foi substituído pelo Conde de Palmela. ${ }^{189}$ Já em 1814, com a queda de Napoleão e a Paz Geral, Portugal reatava as relações comerciais e políticas com a França, em um explícito apoio à volta de Luís XVIII ao

189 Pedro de Sousa Hostein. Conde de Palmela. (1781-1850). Diplomata de grande envergadura, Palmela serviu a Portugal em diferentes Cortes europeias. Durante a primeira metade do século XIX, esteve presente como protagonista ou espectador em diferentes fatos histórico. No governo joanino, especialmente, atuou junto às Cortes de Cádiz, a fim de garantir os direitos de Carlota Joaquina à sucessão do pai, Carlos IV. Em 1813, foi designado ao cargo de Ministro em Londres, onde assumiu o cargo, efetivamente, por volta de 1816; uma vez que mantinha grandes diferenças com o Conde de Funchal. Neste mesmo período, porém, sua atuação foi de grande envergadura. Foi um dos três plenipotenciários portugueses nas negociações do Congresso de Viena (1815), além de ser um dos idealizadores da elevação do Brasil a Reino de Portugal e Algarves. Segundo Oliveira Lima, juntamente com D. Rodrigo de Souza Coutinho e Antonio de Araújo Azevedo, foi considerado a "trindade" dos mais distintos homens de Estado do período. SOUZA, Laura de Mello e. In: NEVES, Lúcia Bastos Pereira das; VAINFAS, Ronaldo (Org.). Dicionário do Brasil joanino... Op. Cit., p. 367-368. 
trono francês. "Para Portugal, a Paz Geral representava uma mudança profunda. Com ela, a extrema dependência em que se encontrava em relação à Grã-Bretanha começava a suscitar reticências, desde logo na própria Corte do Rio de Janeiro", ${ }^{190}$ onde coincidentemente, o Conde da Barca - o principal representante do "partido francês" -, tornava-se o ministro de maior influência do Príncipe Regente. Palmela era um dos seus homens de confiança.

Com a preeminência de Azevedo na política joanina, houve uma explícita mudança nas relações diplomáticas luso-brasileiras. Apesar do protesto veemente de Strangford quanto aos novos rumos, D. João manteve sua decisão a ponto de pedir a sua substituição ao rei da Inglaterra. ${ }^{191}$ Com o fim das guerras napoleônicas na Europa, e a distância continental, foi possível que a Coroa portuguesa vivenciasse uma maior margem de autonomia política, muito bem articulada pelos homens de Estado joanino. A mudança ministerial e as consequências diplomáticas advindas desse fato retratavam os novos tempos. E é justamente dentro da manutenção de um equilíbrio de forças entre as grandes potências europeias que destacamos as preocupações da monarquia portuguesa com as questões culturais. Portugal precisava tornar-se peça de relevância dentro desse complexo tabuleiro político. $\mathrm{Na}$ análise de Pedreira e Costa,

Enquanto a Corte do Rio de Janeiro via a monarquia portuguesa como uma potência vitoriosa, que contribuíra

\footnotetext{
190 PEDREIRA, Jorge; COSTA, Fernando Dores. D. João VI... Op. Cit., p. 286.

191 "A escolha [de Azevedo] suscitou, de resto, o protesto indignado do representante diplomático britânico, lorde Strangford, que procurou mesmo suster a nomeação. E o fez em tais termos que D. João acabou por dirigir-se à Sua Majestade britânica solicitando a sua substituição.” PEDREIRA, Jorge; COSTA, Fernando Dores. D. João VI... Op. Cit., p. 286.
} 
decisivamente com seus sacríficios e o seu Exército para a restauração da Espanha e a derrota de Napoleão, os outros países viam-na como um protetorado secundário da Grã-Bretanha [...] [que] chegara, por intermédio dos seus representantes, a ter assento no seu governo. ${ }^{192}$

Nesse contexto, a principal moeda de troca do governo português era mostrar ao Antigo Continente o quanto o Novo Mundo avançava em muitos campos do conhecimento; o que simbolicamente apregoava a integridade e ascendência dos valores do Antigo Regime à erupção revolucionária. Por esta ótica, o avanço das artes e da ciência faziam parte da agenda central da Coroa, que as considerava uma base fundamental de sustentação política do Império Português.

A entrada de José Liberato Freire de Carvalho na redação d'O Investigador e a saída do Conde de Funchal da embaixada de Londres foram dois fatores de relevância para a mudança das tonalidades políticas no discurso do jornal. Em 1812, o periódico foi criticado pelo poeta e clérigo português, José Agostinho de Macedo, absolutista fervoroso que o considerava tão incendiário quanto o Correio Braziliense. ${ }^{193}$ A partir de 1816, depois do Congresso de Viena e da elevação do Brasil a Reino Unido a Portugal e Algarve, a tônica política tornava-se cada vez mais liberal, apesar do então embaixador em Londres - Conde de Palmela - tentar cercear os artigos políticos de José Liberato Freire de Carvalho, crítico da sua postura no Congresso de Viena. ${ }^{194}$ Palmela era

192 Ibid., p. 292.

193 MACEDO, José Agostinho de. “Cartas aos Senhores Investigadores". In: Obras Inéditas de Agostinho de Macedo. Lisboa: 1900. p. 191.

194 Palmela teve importância capital no Congresso de Viena. Foi o representante português mais influente nas negociações políticas europeias que discutiam a reestruturação do Continente, após a Revolução Francesa. A despeito disso, sua proposta diplomática criou obstáculos a uma intervenção mais efetiva de 
assaz diferente de Funchal, seu antecessor, e considerava que $O$ Investigador deveria ser o jornal do Governo, e não do ministro. Ao referir-se à acirrada "guerra desigual de invectivas" entre O Investigador e o Correio, justificava essa nova diretriz para o jornal.

Para evitar semelhante inconveniente, é necessário pois que o ministro de S. Mag. em Londres não seja ou pareça ser nem redactor nem censor desse periódico. É justo porém que os redatores, a quem S. Mag. se digna auxiliar com a despesa total da impressão do jornal e da remessa dele para os estados, receberam de seus ministros instruções conducentes para os fins louváveis que o governo se propõe [...] de modo que o Investigador possa considerar-se como o Jornal do Governo e não do ministro de Portugal em Londres. ${ }^{195}$

Nesta correspondência, Palmela assumia as diretrizes da política impressa do governo joanino, particularmente no que se referia à imprensa interatlântica produzida em território britânico: a Coroa não só arcava com todos os custos de produção d'O Investigador Portuguez em Inglaterra, como também se preocupava em distribuí-lo nos principais estados do Império Português. Ademais, o ministro instruía seus redatores a escrever de forma moderada e imparcial, "que convém a um jornal adicto aos

Portugal nas negociações. Palmela propunha a Portugal que as negociações deveriam ter um caráter bilateral. Assim sendo, Portugal deveria tratar em separado com a Inglaterra, França e Espanha. Segundo os pesquisadores Jorge Pedreira e Fernando Costa, tal atitude tinha o objetivo de contrabalancear o poder de negociação da Grã-Bretanha no Congresso e também em Portugal. Tal postura, na prática, refletia o pensamento diplomático do Conde da Barca, ministro mais influente de D. João neste período. PEDREIRA, Jorge; COSTA, Fernando. D. João VI... Op. Cit., p. 291.

195 O Conde de Palmela aos Senhores Redatores do Investigador Português. ANTT/ MNE. Londres, 26 de Dezembro de 1816. Apud BOISVERT, G. "Le Comte de Palmela..., p. 482-483 (Grifo nosso). 
interesses bem entendidos do Governo e da Nação" sem, contudo, abdicar da "exposição de uma decente liberdade das suas ideias na certeza de que um governo justo, liberal e tão paternal como o de S. Mag. não se opõe à propagação das luzes nem pode recear que se interpretem nunca mal as suas intenções." ${ }^{196}$

Neste particular o artigo $3^{\circ}$ das Instruções era bem claro: os jornalistas deveriam observar com prudente silêncio as diretrizers do governo de D. João e as atitudes de seus ministros. ${ }^{197}$ Este item ia de encontro com a política diplomática de Palmela, que enfatizava com grande vigor a dimensão europeia do Imperio Português em detrimento da sua porção americana. Porém, sua postura entrava em confronto com o viés geral da diplomacia portuguesa, que valorizava cada vez mais o território americano, efetivamente desde a elevação do Brasil a Reino Unido. Note-se, ainda, que, sobretudo depois dos fatos políticos de contestação ao regime em 1817 nos dois lados do Atlântico - a insurreição Pernambucana no Brasil e a revolta militar de Gomes Freire de Andrade em Portugal -, o discurso liberal e a crítica inversão de papéis entre Brasil e Portugal nas páginas d'O Investigador era explícita, como mostra a reflexão de dezembro de 1817.

A conspiração, e revolta declarada de Pernambuco atentou diretamente contra a autoridade de El Rei e contra a integridade da nação; a conspiração de Lisboa não foi realmente contra El Rei e contra a Pátria, mas só contra o Marechal General Beresford, e influência estrangeira em Portugal. ${ }^{198}$

Os redatores ressaltavam ainda que as penas aos réus portugueses tinham sido mais severas. Segundo os escritores, essa

\footnotetext{
196 Ibid., p. 483 (Grifo nosso)

197 Ibid. (Grifo nosso).

198 IP, Vol. XX, p. 270.
} 
"injusta" diferença de tratamento jurídico era uma das fatalidades intrínsecas à supremacia política do Brasil no Império luso-brasileiro. A progressiva radicalização política de José Liberato Freire de Carvalho impediu um acordo amigável entre ele e Palmela, ambos figuras polêmicas. Em dezembro de 1818, o governo suspendeu definitivamente os subsídios ao Investigador e Carvalho assinava a sua demissão. ${ }^{199}$

O último número do jornal circulou em fevereiro de 1819. A seção "Correspondência" era dirigida "Aos Senhores Subscritores e Correspondentes do Investigador Português em Inglaterra”, participando-os do fim da publicação e agradecendo a eles a honra e liberalidade "com que sempre protegeram esta empresa literária, particularmente nesses últimos tempos". ${ }^{200}$ No mesmo ano, José Liberato Freire de Carvalho fundava o jornal O Campeão Portuguez, cuja linha editorial seria composta pela defesa da Revolução Liberal e crítica ácida acerca dos desmandos administrativos dos ministros e mesmo de D. João VI. Segundo Munaro, esse fato indica que o financimento de José Liberato provinha dos negociantes vinculados ao Club Português em Londres. ${ }^{201}$

$\mathrm{Na}$ prática, o fim d'O Investigador Portuguez em Inglaterra escancarava a aguda crise política vivenciada pela monarquia portuguesa em um âmbito antes inimaginável: iniciava-se o processo de autonomia intelectual dos homens de letras - ainda muito vinculados às intermitências do poder real -, e de seus leitores, que compunham a grande parcela da opinião pública em disputa.

\footnotetext{
199 Para análise detalhada acerca das controvérsias sobre o fim do Investigador, ver. BOISVERT, G. "Comte de Palmela... Op. Cit., p. 472-476.

${ }^{200}$ IP, Vol.XXIII, p. 474. Para a compreesão detalhada do fim d'O Investigador e a relação de Palmela com Vilanova Portugal, ver BOISVERT, G. "Le Comte de Palmela..., p. 472-473.

201 MUNARO, Luís. "A unidade do Reino luso-brasileiro... Op. Cit., p. 7.
} 


\subsection{O Patriota e O Observador Lusitano em Paris: dois periódicos pontuais}

O Patriota apareceu na Corte, em fevereiro de 1813, sob a direção do então redator da Gazeta do Rio de Janeiro, o matemático Manoel Ferreira de Araújo Guimarães. Apesar de ter tido vida curta com apenas três subscrições, entre 1813 e $1814^{202}$, foi "o primeiro jornal brasileiro a publicar artigos densos e analíticos sobre ciência e arte, cultura e letras". ${ }^{203} \mathrm{O}$ prospecto desta nova empreitada cultural na capital do Império já delimitava o diálogo com as produções científicas europeias então vigentes:

[...] socorrido em jornais estrangeiros de decidido merecimento, e (o que é mais) ajudado pelos seus úteis trabalhos, e interessantíssimas descobertas dos sábios de nosso país, esperançado em que nenhum homem de letras quererá escusar-se a cooperação de um periódico, que nos vingará da acusação de ineptos, que nos fazem autores estrangeiros, e por desgraça alguns nacionais. ${ }^{204}$

Mais adiante, o jornalista declarava que o periódico seria "consagrado às Ciências, Literatura, Política, Comércio, Agricultura etc.", sendo a primeira parte destinada às "últimas descobertas nas Ciências e Artes, com preferência as que forem devidas a Autores Nacionais, observações físicas e metalúrgicas do nosso Continente”. ${ }^{205}$ Ao contrário dos “jornais na emigração", o discurso

${ }^{202}$ Foram publicados 18 números. 12 mensais (1813) e 6 bimestrais (1814). Segundo Lorelai Kury, "A leitura do periódico permite a apreensão de um conjunto de temas e questões que constituíram as Luzes imperiais no Brasil". KURY, Lorelai. "Apresentação". In: KURY, Lorelai. (Org.) Iluminismo e Império no Brasil: O Patriota (1813-1814). Rio de Janeiro: Editora Fiocruz, 2007. p. 9.

203 Ibid., p. 9 (Grifos nossos).

204 BNRJ-OR-Doc.37, 5, 13 1B.

205 Ibid. 
inaugural d'O Patriota destacava a agricultura entre os campos do conhecimento considerados prioritários. A Encyclopédie definia a agricultura dentro das ciências da natureza e também a concebia no campo das artes ou, mais especificamente, como a arte de cultivar a terra. "Esta arte é a primeira, a mais útil, a mais ampla e talvez a mais essencial das artes"206, afirmavam os enciclopedistas. Este conceito estava em consonância com os objetivos d'O Patriota que pretendia "formar leitores, agricultores, homens de ciência, escritores" sendo voltado para o "pragmatismo das letras e das artes, [e] à utilidade”. ${ }^{207} \mathrm{Na}$ Introdução da primeira edição, Araújo Guimarães refletia sobre o nascimento de sua empreitada cultural.

Convencido de que apodreciam no esquecimento Obras assaz recomendáveis, e notícias de sobra interessantes, sem que uma mão hábil coligisse e ordenasse aqueles dispersos membros, e formasse um todo digno da atenção pública, doendo-me de que não acordasse a emulação à vista de tantos modelos das nações cultas, como se a posição física retardasse a luz a chegar ao nosso horizonte; cego à insuficiência de minhas forças, mas desperto ao brado da Pátria; eu não hesitei um momento em empreender aquilo, que todos os Literatos, primeiro que eu [sic], haviam pensado, e de que (infelizmente) abriram mão aterrados com os embaraços, que circunstâncias melindrosas tornavam quase insuportáveis. ${ }^{208}$

Muito provavelmente Guimarães se referia ao fim da Sociedade Literária do Rio de Janeiro em 1794. Espaço de intenso

\footnotetext{
206 AGRICULTURE: “Cet art est le premier, le plus utile, le plus étendu, \& peut être le plus essentiel des arts." (Ordre Encycl. Histoire de la Nat. Philos. Science de la Nat. Botan. Agricult.) [Agriculture] [Diderot2] [Page Link 1:183]. Disponível em: <http://encyclopedie.uchicago.edu/>. Acesso em: 1. dez. 2010.

207 KURY, Lorelai. “Apresentação ..., p. 12.

208 O Patriota. Introdução, p. v.
} 
debate intelectual, a Sociedade Literária foi o principal alvo de desconfiança do Conde de Resende, o vice-rei da capitania. A fim de evitar a disseminação dos ideais revolucionários franceses, que acreditava serem discutidos nesse espaço, Resende prendeu os líderes do suposto complô sedicioso: o poeta e advogado Manoel Inácio da Silva Alvarenga, Jacinto José da Silva e Marianno José Pereira da Fonseca ${ }^{209}$. Em 1813, esses ilustrados de destaque no universo intelectual brasileiro se tornaram colaboradores e subscritores d'O Patriota. ${ }^{210}$ Como salientou Marco Morel, a necessidade dessa iniciativa literária visava à conformação e consolidação de uma esfera pública cultural moderna no Brasil..211

Por esta razão, O Patriota contou com subscritores de peso na órbita política e cultural joanina. Para além das figuras da realeza - a Princesa do Brasil, Carlota Joaquina e a Infanta, Maria Izabel - encontramos políticos de grande infulência como Antonio de Araujo de Azevedo (Conde da Barca), o Conde dos

\footnotetext{
209 Diplomado em direito canônico pela Universidade de Coimbra, Manoel Inácio da Silva Alvarenga atuava como Professor de Retórica no Rio de Janeiro no ano de sua prisão. Nesta cidade sua residência tornou-se um importante ponto de encontro intelectual, tanto de reuniões informais quanto as referentes à estruturação da Sociedade Literária. Já o filósofo e matemático Marianno José Pereira da Fonseca (também diplomado por Coimbra) tinha importantes laços de amizade com vários cortesãos luso-brasileiros. SCHULTZ, Kirsten. Versalhes Tropical: império, monarquia e a Corte Real portuguesa no Rio de Janeiro, 18081821. Trad. Renato Aguiar. Rio de Janeiro: Civilização Brasileira, 2008. p. 87.

${ }^{210}$ Para o acesso aos textos desses autores publicados n' O Patriota, ver o índice do jornal organizado por Diana Zaidman, sob a direção de José Honório Rodrigues. As principais obras desses autores são: ALVARENGA, Manoel Inácio da Silva. Sátira dos Costumes. 1813; FONSECA, Marianno José Pereira da. Maximas, Pensamentos e Reflexões Morais por um brasileiro; e SILVA, Jacinto José da. Memória sobre a Cochonilha. (Na Seção de Agricultura e Botânica).

211 MOREL, Marco. "Pátrias Polissêmicas: República das Letras e Imprensa na Crise do Império Português na América”. In: LORELAI. (Org.) Iluminismo e Império no Brasil. O Patriota (1813-1814). Rio de Janeiro: Editora FIOCRUZ, 2007. p. 16.
} 
Arcos e o Conde das Galveias. ${ }^{212}$ A Condessa de Linhares, viúva do Conde de Linhares, cujo nome também aparece na primeira subscrição, ${ }^{213}$ é o principal destaque feminino da lista de assinantes, composta, majoritariamente, por pessoas ilustres da nobreza portuguesa. $\mathrm{Na}$ área administrativa, as figuras de relevo eram a do Intendente Geral da Polícia, Paulo Fernandes Viana e a do físico-mor, Manoel Viera da Silva, autor do livro Reflexões sobre alguns dos meios propostos por mais conducentes para melhorar o clima do Rio de Janeiro. ${ }^{214}$

Quanto aos homens ligados ao comércio livreiro, temos: Francisco Luiz Saturnino, Manoel Joaquim da Silva Porto e Paulo Martin, responsável pela venda da primeira subscrição do jornal na sua loja, localizada na R. da Quitanda, n. 34. Na lista inaugural dos assinantes, o nome do livreiro aparece da seguinte forma: "Paulo Martins [sic] e filhos em Lisboa, 25 ex.." ${ }^{215}$ Muito possivelmente, assim como seu pai, seus filhos estavam ligados ao comércio livreiro no Reino e tinham se encarregado da distribuição desses 25 exemplares da folha para a Imprensa Régia de Lisboa e outras tipografias do Reino que mantinham as devidas

212 D. João de Almeida Melo e Castro (Conde das Galveias) ocupou o cargo de Ministro e Secretário dos Negócios Estrangeiros e da Guerra, entre janeiro de 1812 e janeiro de 1814. Ou seja, era o principal ministro e conselheiro de D. João nas duas primeiras subscrições d'O Patriota; a partir de fevereiro de 1814. 213 Apesar de o Conde de Linhares ter falecido em janeiro de 1812 e a primeira edição de $O$ Patriota ter saído exatamente um ano mais tarde, esse é um importante indício de que este projeto literário tenha sido gestado em vida por Linhares e seu grupo político. Também é possível que ele tenha deixado reservada uma quantia de suas finanças para esse projeto, motivo pelo qual aparece o nome de ambos, Conde e Condessa de Linhares. Ou talvez, o seu nome apareça como uma forma de reverência à sua memória, feita por seus aliados.

214 Rio de Janeiro: Impressão Régia, 1808.

215 O Patriota. Junho de 1813, p. 108. Na 2a subscrição, seu nome aparece "Paulo Martin e filhos em Lisboa, 25 exemplares”, o que dá maior sustentabilidade à nossa hipótese. 
licenças reais. ${ }^{216}$ No universo dos espaços de cultura e seus agentes culturais ligados ao governo de D. João, destacamos: a Biblioteca Pública da Bahia, o bibliotecário da Corte, Luiz Joaquim dos Santos Marrocos, o bispo capelão mor; os diretores da Impressão Régia - José Bernardes de Castro, Marianno José Pereira da Fonseca (ambos colaboradores d'O Patriota) e José da Silva Lisboa - que, juntamente com Francisco da Borja Garção Stockler, também eram censores régios. ${ }^{217}$ Curiosamente, ainda encontramos a assinatura de um Enviado dos Estados Unidos. Este fato talvez possa indicar que, da mesma forma que jornais norte-americanos aportavam no Brasil, eram lidos, editados e publicados na Gazeta do Rio de Janeiro, também a Gazeta e O Patriota poderiam fazer parte do rol de periódicos lidos nos Estados Unidos.

Para além de estreitar a rede de contatos entre os principais agentes culturais do governo joanino, o jornal tinha como principal objetivo divulgar as linhas gerais da concepção desse iluminismo luso-americano. ${ }^{218}$ Diferentemente do Correio Braziliense,

\footnotetext{
216 Sobre a atuação do livreiro Paulo Martin Filho e as suas relações em Lisboa, ver: SOUZA, Simone. Primeiras Impressões... Op. Cit., p. 48-50.

217 Para maiores detalhes sobre as funções e atuação da Direção da Impressão Régia, ver CAMARGO, Ana Maria de Almeida; MORAES, Rubens Borba de. Bibliografia da Impressão Régia... Op. Cit.; MEIRELLES, Juliana. Imprensa e poder..., p. 64-82. Sobre a vida de Lisboa no período tanto quanto sua atuação como censor régio ver ALGRANTI, L. Livros de Devoção, Atos de Censura... Op. Cit., especialmente cap. 4 e 5.

218 A expressão iluminismo luso-brasileiro é da historiadora Lorelai Kuri. Segundo a autora, "O Patriota pretendeu influenciar a própria formação dos homens de letras locais, tanto na qualidade de leitores, quanto na de escritores. Seu didatismo é também manifesto em sua maneira de fundar uma síntese do que era sabido sobre as terras brasileiras. Essa síntese, no entanto, tinha por referência o quadro europeu, com o qual os principais colaboradores estavam familiarizados. Assim, é nessa confluência entre a construção de uma singularidade brasileira, inserida no universo imperial português, e os modelos científicos dos centros europeus que se constitui uma das principais manifestações do iluminismo luso-americano." KURY, Lorelai. "Descrever a Pátria, difundir o saber... Op. Cit., p. 142.
} 
d'O Investigador Portuguez e d'Observador Lusitano em Paris, que discutiam pela perspectiva europeia os benefícios que a arte e a ciência trariam para o progresso do Império Português, o periódico debateria os mesmos temas pela perspectiva americana.

Sendo o principal objeto deste Periódico fazer conhecer este continente, tão ignorado, ou tão desfiguado por aqueles que às cegas, ou prevenidos tem escrito a seu respeito; e desejando aproveitar todas as notícias verídicas, que chegam a nossa mão, temos hoje a satisfação de apresentarmos ao Público o progresso da povoação e civilização dos lugares mais centrais, há pouco desertos ou infestados por nações bárbaras e feroces [sic] ${ }^{219}$

Durante este período, O Patriota circulou no Brasil, em Portugal e na Inglaterra, sendo uma importante fonte de informação da história do país, com ênfase para o viés cultural. ${ }^{220} \mathrm{Com}$ a reflexão supracitada, o redator aprofundava as informações já veiculadas na Gazeta do Rio de Janeiro sobre a criação de uma povoação denominada São Pedro de Alcântara, às margens do Rio Tocantins, onde habitava a nação dos índios Macameirans. $\mathrm{Na}$ Gazeta, Araújo Guimarães havia justificado o novo projeto pelo avanço civilizacional da região: com a população devidamente domesticada, o "país" já poderia usufruir das facilidades comerciais advindas da comunicação por terra entre as capitanias do Pará e do Maranhão. ${ }^{221}$ Aliás, desde a chegada da Corte, o projeto de civilização dos índios brasileiros era uma preocupação da monarquia portuguesa. Já em fevereiro de 1809, era publicada na seção "Avisos" da Gazeta do Rio de Janeiro a Carta Régia de 2

219 O Patriota, Setembro, 1813, p. 61.

220 Para ter acesso à lista dos assinantes d'O Patriota ver Subscrição 1, n. 6, p. 103-108 e Subscrição 2, n. 6, p. 89-91.

221 GRJ. 1813. N65 (Grifos originais). 
de Dezembro de 1808, dirigida ao Governador e Capitão General da Capitania de Minas Gerais e vendida na Loja da Gazeta e do livreiro Manoel Jorge. O documento dava "várias providências sobre a Civilização dos Índios, Navegação do Rio Doce, Cultura, e Mineração dos Terrenos, escolha de Eclesiásticos para a educação Religiosa, e Civil do Gentil, \& c." ${ }^{222}$, já enunciando os diferentes vieses que comporiam esse processo civilizatório.

Já o artigo d'O Patriota enfatizava a trilha do progresso e da civilização detalhadamente arquitetada pelo governador da capitania de Goiás e pelos fazendeiros portugueses que por lá viviam. "Construídas as habitações, se cuidou em estabelecer oficinas, fazer plantações, erigir uma casa de oração e outros místeres"223, revelava o escritor. Com total aprovação do Príncipe Regente, os índios eram "acolhidos" pelos portugueses da região e iam, pouco a pouco, civilizando-se:

Instruídos na nossa língua, doutrinados na Religião, e educados nos usos e costumes; e temos a satisfação de anunciar que amaciados e contentes se dão ao trabalho da agricultura, não tendo fugido um só para as suas aldeias, como muito facilmente poderiam fazer [...] fornecidos de instrumentos, de que careciam, tornados úteis à socieda$d e$, cultivam a terra, e esta lhes paga liberalmente os seus suores. $^{224}$

A tentativa de inserção desses gentios nos códigos culturais do colonizador - como a língua e a religião - tinha o intuito de torná-los mais aptos para o trabalho e, consequentemente, mais úteis na colaboração do progresso da região. Portanto, para tirá-los

${ }^{222}$ Ibid., N44 (Grifos originais).

223 O Patriota, Setembro, 1813, p. 62.

${ }^{224}$ Ibid., p. 63-64 (Grifos nossos). 
da barbárie e torná-los civilizados, o processo de conquista não tinha sido nada pacífico. ${ }^{225}$ A batalha da Junta da Civilização e Conquista dos Índios contra os botocudos foi tema da Gazeta do Rio de Janeiro de 17 de maio de 1809.

O Rio de Janeiro também foi um tópico muito presente nos artigos d'O Patriota. Como mostra a historiadora Tânia Ferreira, os assuntos mais comuns eram "as primeiras ocupações, a luta contra os franceses, a insegurança nas ruas, os principais episódios políticos". 226 Era necessário que os súditos aquém e além-mar, assim como o mundo europeu, conhecessem a história e as transformações da nova capital do Império Português, especialmente as mais recentes e que colocavam D. João na posição de redentor do Novo Mundo. No bojo dessas mudanças, a comunicação entre a Corte e as capitanias brasileiras ganhava grande destaque. Correios e estradas eram abertos para facilitarem a integração do território; o que deu impulso decisivo no que se refere à comunicação interna. ${ }^{227}$ Enfim, se o Brasil vivenciou transformações estuturais significativas no período, fazia parte da política cultural da Coroa que estas fossem amplamente divulgadas. Todos os jornais apoiados e patrocinados pela monarquia destacavam as medidas inovadoras e cumpriam tal finalidade. Na edição de junho de 1814, por exemplo, O Investigador Portuguez anunciava o recebimento dos doze números d'O Patriota, saídos no Rio no ano anterior.

Sobre o processo de conquista dos Macameirans, ver O Patriota. Setembro de 1813. p. 62-64. Sobre a violência na colonização dos Botocudos, ver. Gazeta do Rio de Janeiro. 1809. N.71. Para a análise dessa mesma questão, ver: SILVA, Maria Beatriz Nizza. A Gazeta do Rio de Janeiro (1808-1821): cultura e sociedade. Rio de Janeiro: EDUERJ, 2007. p. 238-242.

226 FERREIRA, Tânia M. Tavares Bessone da Cruz. "Redatores, Livros e Leitores em O Patriota”. In: KURY, Lorelai. (Org.) Iluminismo e Império no Brasil: O Patriota (1813-1814). Rio de Janeiro: Editora Fiocruz, 2007. p. 56.

227 PEDREIRA, Jorge; COSTA, Fernando. D. João VI... Op. Cit., p. 271. 
Vemos com o maior contentamento imaginável quanto as artes e as Ciências prosperam em aquele abençoado país, e como a presença de S.A.R. tem feito indústria e actividades dos habitantes daquelas vastas Regiões [... $]^{228}$

A valorização da presença de El Rei no Brasil era benéfica, sobretudo no que se referia ao avanço das atividades úteis, no campo das artes e ciências, como a Estatística, cujos artigos seriam publicados n' O Investigador "para darmos a conhecer à Europa o interior de um país que por tantos séculos tem estado por assim dizer, escondido aos olhos do mundo, apesar de merecer tanto o ser conhecido e aproveitado". ${ }^{229}$ Já em novembro de 1808 , no artigo denominado "Da Estatística” o redator da Gazeta do Rio de Janeiro esclarecia seus leitores sobre a importância dessa ciência. "A Estatística tem por objeto fazer conhecer as forças físicas, morais e políticas de um País, e se pode comparar à Anatomia; pois ensina a fazer a dissecação do Corpo Social para depois examinar separadamente cada uma de suas partes" ${ }^{230}$

Para além de o novo periódico tratar de temas considerados respeitáveis, também o avanço das reflexões inovadoras de seus colaboradores era exaltado.

Até parece, pela sua tão bem principiada carreira, em que tem desenvolvido grandes esforços sobre objectos mui variados e úteis, que darão mui depressa muito o que aprender e imitar à Mãe Pátria, que desgraçadamente nem sempre tem olhado para as artes e para as Ciências com aquela importância que elas devem merecer a todos os povos, e Governos que não querem fazer uma figura insignificante entre os mais indivíduos da grande família social. ${ }^{231}$

${ }^{228}$ IP, Vol. IX., p. 656.

229 Ibid.

230 GRJ. 1808. N.22.

231 IP, Vol. IX, p. 656. 
Para os redatores d'O Investigador, os colaboradores d'O Patriota estavam aptos tanto a aprender quanto a ensinar à mãe pátria o devido valor que deveria ter as artes e ciências na sociedade. Como podemos notar, a coerência da estratégia discursiva governamental é reiterada nos diferentes veículos de comunicação por eles produzidos, seja a Gazeta do Rio de Janeiro, $\mathrm{OPa}$ triota ou $O$ Investigador Portuguez em Inglaterra. Toda essa valorização real tinha uma razão de ser: como sede da monarquia desde 1808, os olhos da comunidade luso-brasileira que vivia em Londres estavam muito voltados para o Brasil. Já deste lado do Atlântico, era preciso repensar o sentido da história do Império Português. Segundo o historiador Manoel Salgado Guimarães,

Na melhor tradição do iluminismo setecentista, o jornal filiava-se a uma concepção de história como mestra da vida, como condutora dos homens pelo mundo, guiados pelos exemplos hauridos dos homens do passado. História e política parecem indissociáveis nessa perspectiva, uma vez que cada vez mais o exercício desta demanda o conhecimento adequado daquela. ${ }^{232}$

Ao lerem, discutirem e divulgarem na Europa as notícias de diversas naturezas vigentes n'O Patriota, os redatores d'O Investigador não apenas mostravam as transformações políticas $\mathrm{e}$ culturais que paulatinamente vinham ocorrendo no país, mas também participavam ativamente desse processo de mudanças históricas ocorridas na própria concepção do Império Português. ${ }^{233}$ Nesse sentido, exaltar a preponderância do Brasil na

232 GUIMARÃES, Manoel Luiz Salgado. "As luzes para o Império: história e progresso nas páginas de O Patriota”. In: KURY, Lorelai (Org.) Iluminismo e Império no Brasil:.... Op. Cit., p. 67.

${ }^{233}$ Para conhecer as transformações nesta concepção, ver: ALEXANDRE, Valentim, Os sentidos do Império: Op. Cit.; LYRA, Maria de Lourdes Viana. 
prática e a ampla utilidade dos ensinamentos teóricos colocava a discussão do papel das artes e das ciências na esfera pública. Em ambos os lados do Atlântico, a agricultura era o maior exemplo. Em Memória sobre a cultura dos algodoeiros, o renomado médico brasileiro Manoel da Camara Arruda ressaltava a relação do homem com a natureza. ${ }^{234}$ Vejamos:

A necessidade e o acaso são as duas principais mãys ou fontes [sic], donde nascem as ciências e as artes: as necessidades crescem, e se multiplicam à proporção que se civilizam os povos; nos homens que vivem rusticamente, perto, para assim dizer, de uma vida selvagem, as suas necessidades não se estendem a muito: assim as mais antigas artes e ciências devem ser aquelas que interessem a existência e o cômodo, tal qual podiam ter os primeiros homens, vivendo frugalmente, formando quando muito

A utopia... Op. Cit.; SILVA, Ana Rosa Cloclet da. Inventando a Nação:... Op. Cit.; SOUZA, Iara Lis Carvalho. Pátria...Op. Cit.

${ }^{234}$ Manoel da Camara Arruda (1752-1810) era filho do agricultor Francisco de Arruda Câmara e D. Maria Saraiva da Silva. Realizou seus estudos preliminares na cidade de Goiana, Pernambuco, onde foi ordenado padre no Seminário dessa cidade (1773), adotando o nome de Frei Manuel do Coração de Jesus. Estudou na Universidade de Coimbra, em Portugal, e doutorou-se e em Montpellier, na França. Foi correspondente das Ciências de Agricultura em Paris e da Academia Real das Ciências de Lisboa, sendo na época da publicação do artigo, um naturalista empregado ao serviço da monarquia portuguesa, na capitania de Pernambuco. No final do século séc. XVIII, classificou a flora paraibana e produziu inúmeros trabalhos científicos sobre botânica, zoologia e mineralogia. Deixou uma importante bibliografia: Centúria (nunca foi publicada); A memória sobre a cultura do algodoeiro, 1797; Dissertação sobre as plantas do Brasil, 1817; Discurso sobre a vitalidade da instituição de jardins nas principais províncias do país, 1810; Aviso aos lavradores sobre a suposta fermentação de qualquer qualidade de grãos ou pevides para aumento da colheita, Lisboa, 1792; Memórias sobre as plantas de que se podem fazer baunilha no Brasil, (nas memórias da Academia Real das Ciências de Lisboa, v.40, 1814). Disponível em: <http://bndigital.bn.br/redememoria/arrudadacamara.html >. Acesso em: 25 mar. 2011. O Patriota. Janeiro de 1813, p. 22. 
pequenos arraiais, de costumes simples, como eles mesmos, saídos há pouco das mãos da Natureza. ${ }^{235}$

De início, dois aspectos deste artigo nos despertam a atenção: a atualidade de seus ensinamentos na arte de tecer (o texto é de 1797) e o fato de ter sido publicado na seção "Agricultura" já na primeira edição d'O Patriota. Camara indicava mais adiante que a necessidade de sobrevivência era a mola-mestra do homem no caminho para a civilização. Portanto, fazia-se urgente veicular o conhecimento dos principais meios que garantiriam o sucesso deste desafio. "Pelo que a Agricultura dos alimentos, a Medicina, a Cirurgia que interessam imediatamente à saúde, e a existência, devem ocupar o $1^{\circ}$ lugar na ordem dos tempos"236, instruía o homem de ciência. No mesmo ano, era veiculado n'O Investigador Portuguez uma carta política intitulada "Sobre o melhoramento da Agricultura Portuguesa”. ${ }^{237}$ Neste diálogo com os nobres súditos da monarquia, o autor explicava as razões da revalorização da agricultura em Portugal, sobretudo em um momento político tão conturbado.

É dificultozíssimo [sic] poder-se alguém persuadir, que seja possível subsistir Reino algum sem cultura, e sem uma cultura muito ativa, e cuidadosa; quanto esta mais se aumenta [sic], tanto mais forte se faz o povo por esta causa; sendo pelo contrário evidente prova de miséria, pobreza, e pequena povoação as terras incultas. [...].

Ao relacionar a agricultura à prosperidade econômica do Reino, o escritor advertia os governos de sua responsabilidade no encaminhamento deste processo.

235 CAMARA, Manoel Arruda. "Memória sobre a cultura dos algodoeiros", 1797. In: O Patriota. Janeiro 1813, p. 23 (Grifos nossos).

236 CAMARA, Manoel Arruda. "Memória sobre a cultura dos algodoeiros", 1797. In: O Patriota. Janeiro 1813, p. 23 (Grifos nossos).

237 IP, Vol. VIII, p. 223-228. 
A natureza dos governos é quem determina a sorte dos lavradores, e a maior, ou menor vigilância da cultivação. [...] E que preciosos exemplos não colhem os homens da cultura! Nenhuma dependência nos estados deixa [sic] de ter com ela necessária conexão: alimentos, povoação, artes, comércio, navegação, exércitos, rendas, classes, riqueza: tudo a agricultura sustenta, tudo dela depende, e quanto mais cresce e se revigora, tanto mais os Reinos florescem, e se aumentam por terem no seu âmago maior número de recursos. ${ }^{238}$

A agricultura como meio indispensável do esplendor político da nação portuguesa. Eis o debate que o escritor desejava reavivar na esfera pública, sobretudo para os ministros reais nos dois lados do Atlântico, os vigilantes da sociedade luso-brasileira. O recado estava dado: era, agora, necessário ver florescer os frutos. Entretanto, não era novidade que o triunfo deste empreendimento dependia do modo como a monarquia portuguesa concebesse a educação dos lavradores, em particular, e de seus súditos, em geral. "Separar o menos que for possível a prática da teoria. Quem possui a primeira com uma facilidade compreende e alcança os princípios teóricos e deles se serve utilmente para dirigir as suas operações"239, afirmava o médico português Francisco Solano Constâncio, ao debater as "condições essenciais de um bom método de ensinar a fundo as ciências naturais e todas as artes práticas" ${ }^{240}$

No raiar de 1815, este mesmo médico anunciava ao público o nascimento d'O Observador Lusitano em Paris. De sua autoria, o jornal circulou na capital francesa entre janeiro e abril do

\footnotetext{
238 Ibid., p. 223-224.

239 CONSTÂNCIO, Francisco Solano, "Ideias sobre a Educação da Mocidade portuguesa...” Op. Cit., p. 396.

240 Ibid.
} 
dito ano. Diferentemente do Correio Braziliense e d'O Investigador Portuguez em Inglaterra, ambos produzidos em Londres, o título do novo periódico já delimitava o locus onde as ideias seriam debatidas: o "jornalismo na emigração" também era pensado, produzido e debatido em Paris, a "inimiga" capital revolucionária e principal centro político de Napoleão Bonaparte e seus aliados, cuja queda ocorrera em finais de 1814. Com o Observador Lusitano em Paris, Solano Constâncio tinha o objetivo de refletir sobre o destino político da Europa, com foco particular para a monarquia portuguesa.

Contudo, a volta inesperada de Napoleão a Paris e o governo dos Cem Dias foram os fatores responsáveis pela vida efêmera d'Observador Lusitano, que tinha como seu redator um homem cuja "envergadura intelectual e a formação de suas convicções liberais, não cedia em nada a Hipólito José da Costa". ${ }^{241}$ Porém, diferentemente de Hipólito, a sua pena esteve muito mais voltada ao enaltecimento do papel político exercido pela monarquia portuguesa no período joanino; o que não o eximia de fazer suas próprias críticas, mormente no que se referia ao sistema educacional português. Neste particular, entretanto, tal problemática era estendida a todo o continente europeu: nenhuma nação dita civilizada era poupada em suas reflexões - Inglaterra, França e Alemanha, respeitando as suas pecualiridades históricas, também tinham muito a melhorar. Segundo o homem de letras, a educação europeia ainda era para uma pequena elite de letrados. ${ }^{242}$

Na seção "Discurso Preliminar" d'Observador Lusitano em Paris, o jornalista circunscrevia o seu plano de trabalho por dois

\footnotetext{
${ }^{241}$ BOISVERT, G. "La Presse Periodique Portugaise de Londres..., Op. Cit., p. 72-73. ${ }^{242}$ CONSTÂNCIO, Francisco Solano. "Ideias sobre a Educação da Mocidade portuguesa...", Op. Cit., p. 390-401.
} 
pilares centrais da concepção de imprensa europeia do período: as bases da responsabilidade de um redator e o diálogo profícuo com os seus leitores. ${ }^{243}$ Já de início, Constâncio ressaltava a relação existente entre política, arte e ciência para a "propagação das luzes, e a extensão das relações comerciais entre as nações" ${ }^{244}$ Tal proposição ganhava maior notoriedade sobretudo em meio à ebulição política e militar do Velho Mundo advinda da Revolução Francesa. "A política, que nos séculos passados era exclusivamente a ciência dos gabinetes e a ocupação dos homens de Estado, se tem tornado nos nossos tempos o objecto da curiosidade de todos", afirmava o escritor. ${ }^{245}$ Desde o final do século XVIII, a política passava a ser concebida como um corpo de conhecimento autônomo, com conceitos bem definidos ${ }^{246}$ tanto pelos governantes, quanto pela própria elite ilustrada. Mormente com o sucesso da Encyclopédie, esta compreensão impunha aos detentores do poder político e à sociedade em geral uma nova discussão acerca dos usos e conceitos da ciência. Como afirma o historiador João Luís Lisboa, pouco a pouco se ia formando uma "consciência da necessidade de conjugar saber e atuação política, como [também] é clara a relação entre intervenção científica e o questionar das estruturas sociais e económicas". ${ }^{247}$

Esta relação fica mais evidente no discurso do médico no periódico, quando ele agradece o fato de ter sido pensionista do governo português em 1791, ano em que se diplomou nos estudos realizados em Edimburgo e Londres: "À munificiência desta

${ }^{243}$ MEIRELLES, Juliana Gesuelli. Imprensa... Op. Cit., p. 91-154.

${ }^{244}$ CONSTÂNCIO, Francisco Solano. "Ideias sobre a Educação da Mocidade portuguesa... Op. Cit., p. ij.

${ }^{245}$ Ibid. (Grifos nossos).

246 LISBOA, João Luís. Ciência e Polílita: ler nos finais do Antigo Regime. Lisboa: CLC/UNL, 1991. p. 157.

${ }^{247}$ Ibid., p. 100. 
Senhora ( $\mathrm{D}^{\mathrm{a}}$ Maria I) liberalmente continuada por seu Augusto Filho, o Príncipe Regente, devo em grande parte a minha educação". Tal atitude fazia parte da expedição empreendida pela Coroa, cuja finalidade era a aprendizagem e aperfeiçoamento da medicina e da cirurgia, considerada pelo escritor uma importante ciência ${ }^{248}$ para o avanço do Reino.

Principalmente diante dos avanços científicos e tecnológicos propugnados pela Revolução Industrial na Europa, a questão da especialização do trabalho ganhava cada vez mais centralidade. Na Inglaterra, particularmente, a argumentação liberal de John Locke teve muita aceitação. Ao conceber a constituição do Estado como uma sociedade anônima cujos acionistas são os proprietários, o filósofo colocava em pauta o lugar do trabalhador na sociedade civil. Para a historiadora Maria Stella Bresciani, tal concepção

Possibilitou diferenciar a propriedade do corpo das outras formas de propriedade e localizar o trabalhador dentro da sociedade do trabalho mas fora da comunidade política. [...] A imagem pública do trabalho relaciona-se especificamente com o mercado, não vem colada à imagem do cidadão politicamente ativo. ${ }^{249}$

Diante dessas mudanças de ordem sociopolítica, a questão da organização do espaço público na Inglaterra era intrínseca às tensões referentes à determinação do sistema de trabalho. O processo de autonomização das artes e dos ofícios - já muito

\footnotetext{
${ }^{248}$ O Observador Lusitano em Pariz..., p. 83. Para uma análise mais detalhada sobre o ensino da medicina em Portugal, ver: SOUSA, Maria Leonor Machado de. "The Ghost" e Francisco Solano Constâncio. Lisboa: Universidade Nova, 1978. p. 10-22.

249 BRESCIANI, Maria Stella Martins. Londres e Paris no século XIX. O espetáculo da pobreza. 2. ed. São Paulo: Ed. Brasiliense, 1984. p. 89.
} 
presente na Europa do início do século XIX -, teve, em estágio mais avançado, a especialização da sociedade industrial, que passou a reger suas atividades gerais. Tal fato impôs novas reflexões dos homens de letras europeus. É justamente diante de tal realidade que Solano Constâncio pautava a temática de um importante ensaio, em que discutia a formação da mocidade "à virtude, às ciências e às artes úteis". ${ }^{250}$ Ao valorizar a educação como cerne central para o progresso científico, concebia-a no campo das artes, isto é, como a arte de ensinar ${ }^{251}$, defendendo a necessidade de um método eficiente de ensino das "ciências que se compõem da Medicina ou arte de prevenir as doenças dos Homens". ${ }^{252}$ De acordo com o dicionário de Moraes e Silva, a educação estava vinculada à criação de alguém, ao ensino das coisas, aquilo que aperfeiçoa o entendimento ou dirige a vontade e, sobretudo, àquilo que respeita ao decoro. ${ }^{253}$ Apesar de Francisco Solano Constâncio ter vivido boa parte da sua vida em Paris, ele foi sempre um súdito leal da monarquia portuguesa, mesmo tendo se naturalizado francês, por volta de $1820 .{ }^{254}$

A veiculação dos descobrimentos no campo das artes e das ciências foi um dos destaques das preocupações do médico português nesta obra periódica, política e literária como a definiu em seu "Discurso Preliminar". Nas palavras do escritor, dava-se preeminência, nomeadamente, "[a] aqueles [conhecimentos] que

\footnotetext{
250 CONSTÂNCIO, Francisco Solano. "Ideias sobre a Educação da Mocidade portuguesa nas Ciências Físicas e nas Artes”. In: SOUSA, Maria Leonor Machado de. Portugal e o mundo nos primeiros decênios do século XIX: Francisco Solano Constâncio. Lisboa: Arcádia, 1979, p. 383.

251 Ibid., p. 385.

252 Ibid., p. 388.

253 Dicionário Moraes e Silva, Vol. I., p. 647.

${ }^{254}$ Cf. SOUSA, Maria Leonor Machado de. "The Ghost” e Francisco Solano Constâncio. Lisboa: Universidade Nova, 1978. p. 88.
} 
em julgar poderem ser com mais utilidade adoptados entre nós, serão expostos com clareza acompanhados das reflexões práticas." Pedagogicamente, o redator incitava de forma explícita os seus leitores a fazerem uma leitura ativa das novas informações surgidas nestes campos do saber para, assim, executarem com inteligência os inventos úteis à manufactura. ${ }^{255} \mathrm{~N}^{\prime}$ Observador $\mathrm{Lu}$ sitano em Paris, a agricultura aparecia como uma de suas preocupações principais, sendo considerada central para o desenvolvimento econômico da monarquia portuguesa:

A agricultura mãe de todas as artes e origem principal da riqueza dos povos, acabrunhada em Portugal como em quase toda a Europa tem feito rápidos progressos, terá um distinto lugar no Observador; e nele se achará uma notícia do que aparecer de mais interessante sobre este importantíssimo objecto $[\ldots] .{ }^{256}$

Se, para Francisco Solano, a agricultura era concebida dentro do campo das artes, para o acadêmico português, Mendes Trigoso, a mesma atividade era a primeira das ciências, por isso mesmo servia de base e prosperidade dos estados. ${ }^{257}$ Mesmo que os dois pensadores vissem a agricultura por óticas relativamente diversas - da arte e da ciência - também, para ambos, a agricultura tinha uma importância capital para o progresso do Estado e dos povos. Nessa altura, por “'Sciencia e Artes' [sic] entende-se geralmente a procura da realidade terrena que o homem pode conhecer e sobre a qual pode, em muitos casos, agir" ${ }^{258}$, afirma João Luís Lisboa.

\footnotetext{
255 “Discurso Preliminar" In: O observador Lusitano em Paris, p. iv.

${ }^{256}$ Ibid., p. iv-v.

257 Cf. Memórias Económicas da Academia das Ciências de Lisboa, t. V., 1815, p. 63. (Grifo nosso).

${ }^{258}$ LISBOA, João Luís. Ciência e política... Op. Cit., p. 89-90.
} 
Apesar das críticas de Francisco Solano Constâncio aos governadores do Reino no que concerne à lógica da censura portuguesa em relação aos periódicos produzidos no exterior (especialmente em relação às diferenças de comportamento diante do seu periódico e dos produzidos em Londres), o que muitas vezes prejudicava a sua ação na formação da opinião pública, o intelectual sempre respeitou o decoro vigente na política cultural do Império português. Na seção "Advertência", Francisco Solano justificava o seu comportamento:

Contra a minha esperança, contra a justiça, e apesar das representações de pessoas de maior consideração e caráter ao atual serviço de S.A.R. o Príncipe Regente, consta-me que a Regência de Portugal recusou de me nomear em Lisboa um censor, que examinando o meu jornal apenas os $\mathrm{N} .^{\circ}$ s chegassem, me forrasse a inevitável demora das três censuras a que estão sujeitas todas as obras impressas; favor que antes de 1808 se concedia em Portugal a todo o editor de obras periódicas. Este rigor, causando uma grande demora diminui singularmente o valor de uma obra periódica, cuja parte política se recomenda principalmente pela novidade dos fatos que encerra. Se S.A.R. residisse em Lisboa, estou bem certo que não me trataria pior que os escritores periódicos de jornais portugueses em Londres, os quais, à sombra de proteção inglesa do agente dos paquetes, introduzem em Portugal e nos seus domínios, sem maior obstáculo nem censura, as suas produções, que nem sempre se distinguem pela decência, moderação e respeito com que falam dos membros do governo português, dos funcionários e empregados da nossa Corte, designando até pelos seus nomes as pessoas que são o alvo dos seus bem ou mal fundados ataques. ${ }^{259}$

Ainda sobre a determinação da Regência, Constâncio destacava o fato de a censura ter ocorrido anteriormente à leitura

259 O Observador Lusitano em Paris, N. ${ }^{\circ}$. Maio de 1815, p. 652-653. 
dos seus primeiros cadernos. Segundo o autor, esta atitude "enigmática" dos governadores do reino seria desvendada ao longo do tempo pela postura desses homens diante das novas publicações. O que lhe chamava a atenção, porém, era a sua posição particular neste contexto: escrevia da França e ainda assim não tinha amarras políticas. ${ }^{260}$ Nas suas palavras, ele se autodesignava um "autor que escreve como pensa, que não serve nem nunca serviu governo algum estrangeiro, que não foi prescrito, nem fugiu da pátria!" ${ }^{61}$ A contribuição literária e científica de maior destaque no currículo de Constâncio, no entanto, foi a obra Annaes das Sciências, das Artes e das Letras, também publicada em Paris, entre os anos de 1818 e 1822. Como redator principal desta obra, o médico anunciava seus objetivos:

Oferecer à sua pátria, e a todos os outros países, que com ela constituem a soberania da Real Casa de Bragança, um extrato resumido, mas exato, dos progressos das luzes na Europa, preferindo, na seleção, aqueles objetos, que tiverem relação mais imediata com as nossas precisões e, conveniência, e mais analogia com o estado físico e moral da Nação. ${ }^{262}$

O Prospecto dos Annaes foi publicado na íntegra n'O Investigador Portuguez em março de 1818 e ressaltava o progresso que as ciências e as artes têm tido nos últimos trinta anos na Europa culta. ${ }^{263}$ Um ano depois, em março de 1819, a Gazeta do Rio de

260 Sobre a censura dos periódicos franceses durante a Revolução Francesa e o Período Napoleônico ver DARNTON, Robert; ROCHE, Daniel. Revolução Impressa: a imprensa na França (1775 - 1800). São Paulo: Edusp, 1996; NEVES Lúcia M. Bastos P. Napoleão Bonaparte: ... Op. Cit.

${ }^{261}$ O Observador Lusitano em Paris, N. ${ }^{\circ}$. Maio de 1815, p. 653.

262 IP, Vol. XXI. p. 84.

${ }^{263}$ Ibid., p. 83. 
Janeiro também anunciava as novas diretrizes dessa empreitada cultural. Participava aos seus

[...] assinantes, correspondentes e mais pessoas residentes nos domínios portugueses, ou em países estrangeiros" que se encarregavam de "comprar e expedir, a quem desejar, quaisquer livros, estampas, mapas geográficos, máquinas, modelos, instrumentos de física e química [...] e em geral todos os objetos das relativos às Ciências e às Artes, pelos preços de catálogos, e das fábricas, tudo da melhor qualidade e sem defeito. ${ }^{264}$

Segundo o anúncio, os interessados deveriam enviar suas cartas diretamente ao diretor dos Annaes, José Diogo de Mascarenhas, residente na Rua des Grands-Augustins, n. 5, em Paris. ${ }^{265}$ Como já anunciado no Prospecto, a Política seria objeto excluído nos Annaes, exceto quando tratasse de atos importantes "das diversas Potências, que forem relativos à Agricultura, Indústria, Comércio e Educação Pública". ${ }^{266}$

Como vimos, a missão dos homens de imprensa era discutir os melhores caminhos do progresso para que a sociedade civil os interiorizasse e praticasse seus ensinamentos: assim, trilhava-se o caminho para que a sociedade luso-brasileira fosse instruída e educada dentro da concepção de progresso da época, cujo sentido estava intrínseco ao adiantamento em proveito das artes e ciências, como atesta o dicionário Morais e Silva. ${ }^{267}$ Ainda nas palavras de Francisco Solano Constâncio, "sem esta condição [a união da teoria e prática] é quase impossível conseguir um grau

\footnotetext{
264 GRJ. 1819. N.26 (Grifo do Original).

265 Ibid. (Grifo do Original).

266 IP, Vol. XXI. p. 84.

267 Verbete PROGRESSO. 1813, p. 510. <http://www.brasiliana.usp. br/dicionario/2/progresso >. Acesso em: 03 fev. 2011.
} 
notável de superioridade; e é unicamente por tal sistema que cada nação tem em diversas épocas adquirido a preeminência nas artes, nas ciências, na navegação, na arte da guerra etc." ${ }^{268}$ Todos esses exemplos demonstram a força do pragmatismo pedagógico veiculado pelos seus diversos agentes culturais que atuavam na imprensa periódica, considerada um importante pilar da política cultural vigente no Império Português.

A formação intelectual dos vassalos ilustrados da corte luso-brasileira também adentrava em outro terreno de sociabilidade cortesã: os teatros régios. Em um momento de profundas transformações políticas, o olhar sobre a civilização dos costumes e a reiteração da aliança entre o rei e a sociedade era uma questão central que devia ser apregoada. Neste cenário, a constituição de teatros régios e a veiculação de peças teatrais de amplo viés moralizante apareciam como parte fundamental da política cultural joanina intrínseca à sustentação do Império Português nos dois lados do Atlântico, como veremos no próximo capítulo.

${ }^{268}$ CONSTÂNCIO, Francisco Solano, "Idéias sobre a Educação da Mocidade portuguesa... Op. Cit., p. 396. 